
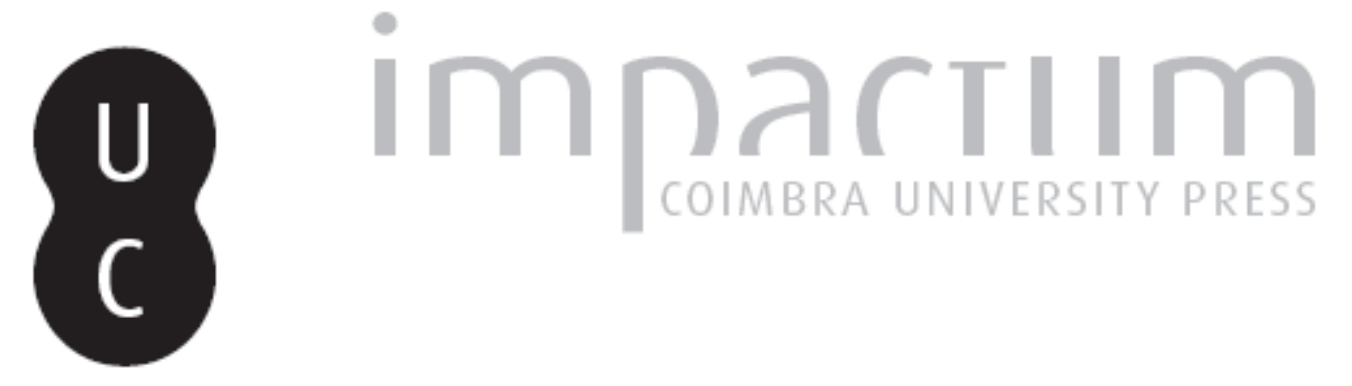

\title{
Os inícios do Positivismo em Portugal: o seu significado político-social
}

Autor(es): $\quad$ Catroga, Fernando de Almeida

Publicado por: Imprensa da Universidade de Coimbra

URL persistente:

URI:http://hdl.handle.net/10316.2/43977

DOI:

DOI:https://doi.org/10.14195/2183-8925_1_9

Accessed : $\quad$ 26-Apr-2023 15:47:02

A navegação consulta e descarregamento dos títulos inseridos nas Bibliotecas Digitais UC Digitalis, UC Pombalina e UC Impactum, pressupõem a aceitação plena e sem reservas dos Termos e Condições de Uso destas Bibliotecas Digitais, disponíveis em https://digitalis.uc.pt/pt-pt/termos.

Conforme exposto nos referidos Termos e Condições de Uso, o descarregamento de títulos de acesso restrito requer uma licença válida de autorização devendo o utilizador aceder ao(s) documento(s) a partir de um endereço de IP da instituição detentora da supramencionada licença.

Ao utilizador é apenas permitido o descarregamento para uso pessoal, pelo que o emprego do(s) título(s) descarregado(s) para outro fim, designadamente comercial, carece de autorização do respetivo autor ou editor da obra.

Na medida em que todas as obras da UC Digitalis se encontram protegidas pelo Código do Direito de Autor e Direitos Conexos e demais legislação aplicável, toda a cópia, parcial ou total, deste documento, nos casos em que é legalmente admitida, deverá conter ou fazer-se acompanhar por este aviso.

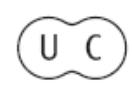




$$
\text { INSTITUTO DE HISTÓRIA E TEORIA DAS IDEIAS }
$$

\title{
REVISTA DE HISTÓRIA $D A S$ IDEIAS
}

\author{
VOL. I
}

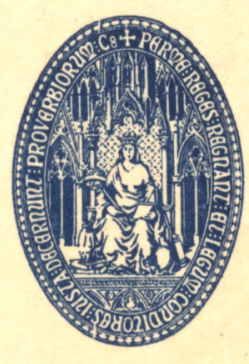

UNIVERSIDADE DE COIMBRA 


\title{
OS INÍCIOS DO POSITIVISMO EM PORTUGAL
}

\author{
O SEU SIGNIFICADO POLÍTICO-SOCIAL
}

\section{A SOCIOLOGIA do POSITIVISMO}

O movimento positivista português foi um fenómeno essencialmente sociológico, já que, mesmo quando incidiu sobre as ciências da natureza, a sua utilização viu-se mediada por essa intenção. Em nosso juízo, isso ficou a dever-se ao momento histórico que o necessitou e à sua capacidade de responder em termos doutrinais aos interesses das classes sociais intermédias. Daí que esta adaptabilidade viesse a traduzir-se no estreito acasalamento que, a partir das três últimas décadas do séc. XIX, se deu entre o movimento que foi a expressão política desse grupo - $\mathrm{o}$ republicanismo - $\mathrm{e}$ a corrente positivista.

Tanto um movimento como outro foram, contudo, tributários das ideias e dos acontecimentos franceses. Por isso, toda a tentativa que vise estudar a especificidade deste acasalamento entre nós exige a prévia descrição da realidade ideológica e política que lhe serviu de ponto de referência.

\section{A emergência do sociologismo positivista}

No século XIX, o projecto sociológico-positivista surgiu no tempo e no espaço epistemológico francês como uma consequência directa das contradiçðes geradas no seio da sociedade oitocentista pós-revolucionária (1).

(1) Ao longo deste estudo, nem sempre se faz uma distinção entre sociologia positivista e filosofia positivista. Embora para nós não sejam realidades inteiramente coincidentes, o certo é que a sistemática de Comte 
Os antagonismos sociais provocados pelo desenvolvimento das forças produtivas em sentido industrialista mostraram à evidência que a realidade social era uma entidade mutável, autónoma, análoga à fenomenalidade natural e, portanto, capaz de ser observada e experimentada. Por outras palavras, as revoluções burguesas, sobretudo a francesa, modificaram por completo as concepções do homem face à sua situação no cosmos natural e político (1). A permanente mudança social resultante das relações de produção capitalistas, ao mesmo tempo que subverteu as velhas mediações entre o indivíduo e a sociedade - família, corporações, igreja - exigiu uma nova explicação do mundo social. Isto é, pela primeira vez, estavam criadas as condições para que, em nome do racionalismo cientista, a sociedade se interrogasse a si mesna, contestasse as suas normas, o seu funcionamento e a sua estrutura, pois, ao contrário das concepções gregas e medievais, tornou-se uma realidade em si, natural e auto-suficiente. Desdivinizou-se, em suma (2).

Ora, para a realização de tal desiderato não serviam as concepções filosóficas e religiosas produzidas pelas sociedades pré-industriais. Assim, se a Cidade grega tinha encontrado o seu fundamento numa metafísica do Inteligível, se a Idade Média se hierarquizou socialmente segundo uma concepção teocêntrica, se a modernidade atomizou o indivíduo, separando-o simultaneamente de Deus e dos outros homens,

permite esta coincidência, pois, se a filosofia aparece como a sistematização de todo o saber científico, é a sociologia dinâmica que define as leis dessa mesma sistematização. No entanto, para além desta razão lógica, o certo é que, em Portugal, excluindo domínios muito restritos, o positivismo apareceu como sinónimo de sociologismo. Sobre o significado do conceito de filosofia e suas relações com as ciências em Augusto Comte, veja-se Georges Gusdorf, Introduction aux Sciences Humaines, Paris, Éditions Ophrys, 1974, pp. 349 e ss..

(1) «É preciso, portanto, que a sociedade, na sua imagem colectiva, deixe de ser passiva para se tornar activa, criadora, para dizer tudo, histórica» (G. Duvignaud, Sociologia, Porto, Liv. Paisagem, 1971, p. 17). Veja-se também GeOrges Gusdorf, op. cit., pp. 365-371.

(2) Veja-se Carlos Moya, Sociologos y Sociologia, Madrid, Siglo XXI de España, 1970, pp. 14-33; GaSton RichaRd, La Question Sociale et le Mouvement Philosophique au XIXe siecle, Paris, Armand Colin. 1914, pp. 1-18; Georges LaPassade et René Louroux, Clefs pour la Sociologie, Paris, Seghers, 1971, pp. 9-10; Jean Lacroix, La Sociologie d'Auguste Comte, Paris, P.U.F., 1967, pp. 1-12; André Akoun, La Sociologie, in Françors Châtelet, «Histoire de la Philosophie», vol. 7, Paris, Hachette, pp. 109-129. 
ao contrário, a sociedade industrial, desdivinizada, tinha de responder a necessidades geradas pelas novas contradições sociais: explicar a totalidade social segundo critérios positivos, de modo a permitir o controlo racional do homem sobre o seu próprio destino, individual e colectivo (1).

Portanto, foi no espectáculo agónico das contradições sociais que se produziu a inquietação, o desafio, a perspectiva nova que gerou o projecto sociológico (2), dado que a aceleração da luta de classes levou a tentativas de apropriação cognitiva do real social que fossem capazes de a anular ou superar. Sendo assim, pode dizer-se que a Sociologia é filha do industrialismo. Contudo, esta tese exige a resposta à seguinte pergunta: por que é que ela surgiu em França e não na Inglaterra, a pátria da primeira revolução burguesa (séc. XVII)?

A razão explicativa encontramo-la na forma específica como se deu a revolução burguesa em cada uma dessas formações sociais concretas. Como se sabe, o processo revolucionário instaurador de um poder político capitalista em Inglaterra seguiu uma via diferente em relação ao Continente. A característica de classe deste processo revolucionário consistiu em marcar o início do estabelecimento do modo de produção capitalista por meio da capitalização da renda fundiária. Assim, as revoluções de 1640 e 1688, sendo objectivamente burguesas, centraram-se à volta da luta entre sectores da burguesia e fracções da nobreza, uma das quais, devido à natureza do desenvolvimento comercial e industrial dominante (sector dos lanifícios), estava interessada em capitalizar ao máximo as grandes explorações agrícolas - zonas de pastagens - e, assim, por necessidade de emparcelamento, liquidar a pequena exploração. Deste modo, o processo de hegemonização produziu, ao nível social, a transformação de uma parte da nobreza em burguesia comercial e industrial, isto é, levou a que os interesses de uma grande parte da nobreza terratenente coincidissem com os da burguesia urbana.

Esta forma específica implicou, no campo político-jurídico, que o bloco dominante - sectores da nobreza e burguesia - não necessitasse de operar de imediato uma profunda transformação no tipo de estado feudal. Em consequência, algumas das suas estruturas perduraram mesmo depois da revolução política, o que explica a permanên-

(1) Veja-se André Akoun, op. cit., pp. 111-115; Carlos Moya, op. cit., pp. 13-20.

(2) Veja-se Jean Duvignaud, op. cit., pp. 12 e 15-16. 
cia de características feudais nas tradições políticas inglesas( ${ }^{1}$ ). $\mathrm{O}$ mesmo, diga-se, aconteceu às formas concretas da ideologia prática, a qual só gradualmente se foi aburguesando.

A transição do feudalismo para o capitalismo em Inglaterra não foi, portanto, um fenómeno que implicasse uma revolução total. A política de alianças ao nível do bloco hegemónico conduziu a que o processo de ruptura fosse essencialmente económico (a instauração das relaçðes de produção capitalisia é muito anterior ao século XVII) e só parcial e posteriormente político e ideológico. Ora, como veremos, uma das condições epistemológicas necessárias ao aparecimento do projecto sociológico encontrava-se na possibilidade objectiva de se poder perspectivar a sociedade como uma totalidade autónoma e onticamente constituída. Tal não se deu no horizonte da revolução burguesa em Inglaterra. A par da permanência de uma estrutura ideológica cimentada à volta de normas de conduta feudalizantes, criou-se antes a necessidade cognitiva de se explicar em termos regionais (embora dando-lhe um valor universal) a fenomenalidade da instância social sujeita a profundas transformações: os fenómenos de produção, distribuição e consumo. A esta luz compreende-se melhor o forte desenvolvimento da Economia Política inglesa e o carácter empírico e técnico que, mais tarde, veio a caracterizar as ciências sociais nos países anglo-saxónicos (2).

O caso francês foi radicalmente diferente. A imposição hegemónica do modo de produção capitalista implicou uma ruptura total com as estruturas económicas, políticas e ideológicas do Antigo Regime. Aqui e independentemente de adesões grupais ou individuais, não houve cisão entre fracções da nobreza, nem alianças globais com a burguesia. Pelo contrário, enquanto classes, a nobreza e o clero procuraram obstar ao avanço da burguesia e, assim, esta teve a necessidade de levar a cabo uma revolução total (3). Consequentemente, a sociedade aparece no horizonte dos ideólogos burgueses, antes e depois da revolução, como uma realidade heterogénea e complexa, mas unificada, possuindo uma dinâmica própria e constituída de partes necessariamente interconexas $\left({ }^{4}\right)$.

(1) Veja-se Nicos Poulantzas, Pouvoir Politique et Classes Sociales, vol. 1, Paris, Maspero, 1971, pp. 179-184.

(2) Veja-se Carlos Moya, op. cit., p. 15.

(3) Veja-se Nicos Poulantzas, op. cit., pp. 164-191.

(4) Veja-se Carlos Moya, op. cit., pp. 13-15. 
Assim se torna claro que o primeiro projecto sociológico - o de Augusto CомтE - tenha nascido em contraposição à economia política e que a diferença radical entre ambas esteja em que uma, explicando fenómenos parcelares e epocais, queria que as suas conclusões fossem válidas para todo o sempre; a outra, a Sociologia, contestava não só a sua unilateralidade e o seu imperialismo, como a sua pretensão a um sabei absoluto (1).

No entanto, se a conjuntura social decorrente da Revolução Francesa pode explicar a necessidade de se proceder à apropriação cognitiva das sociedades humanas, a irrupção de uma nova ciência, ou de uma tentativa de cientificação, é, contudo, um fenómeno complexo em que pesam igualmente condicionantes de carácter ideológico e científico. Em França foi possível pensar-se na construção de uma ciência que explicasse as leis da totalidade social dado que, para além da determinação, em última instância, da estrutura socioeconómica, confluíram factores ideológicos (uma maior influência do pensamento racionalista e proliferação, desde cedo, de concepçðes socializantes e tradicionalistas que contestavam o atomismo social burguês) e científicos (desenvolvimento da Biologia - Bichat, Vicq d'Azyr, Blainville, Cabanis, Pinel, Escola de Mompilher) que, tal como se pode notar pela leitura atenta da obra de Augusto ComTE, foram fundamentais na criação do clima de optimismo cientista e do paradigma epistemológico que levaram à primeira tentativa de se construir uma sociologia (2).

Com efeito, a confiança nas capacidades da razão para desvendar os segredos da natureza, consolidada pelos avanços da física, química e biologia, estendeu-se aos fenómenos sociais. Ora, quanto à dimensão epistemológica, a sociologia nasceu sob o signo do ideal aristotélico de ciência. Só haveria conhecimento do geral e, dentro desta generalidade, a explicação da fenomenalidade social exigiria que a parte fosse perspectivada em função do todo. A ideia de consensus e de lei natural eram, portanto, postulados necessários

(1) Veja-se A. Сомте, Cours de Philosophie Positive, vol. 4, Paris, J. B. Baillière et Fils, 1869, pp. 193-208. Sobre a importância da polémica anti-economista na formação do projecto sociológico de A. Comte, veja-se Pierre Arnaud, Le «Nouveau Dieu» - Préliminaires à la Politique Positive, Paris, Libraire Philosophique J. Vrin, 1973, pp. 22-78.

(2) Veja-se Carlos Moya, op. cit., pp. 15-46. Veja-se também Georges GUSDORF, op. cit., pp. 291-308. 
à prática científica no domínio social (1). Por isso, dada a coincidência do objecto real, a aparelhagem conceptual, metodológica e terminológica da Biologia aparecia como a condição de possibilidade que faltava para que um novo reino do saber se abrisse à inteligência (2). Por outras palavras, a plena cientificação da biologia (sécs. XVIII-XIX), sobredeterminada pela conjuntura socioeconómica e ide Jlógica, teria produzido o momento epistemológico capaz de fazer emergir a nova ciência. E, como pensava Сомте, a analogia entre as realidades referenciadas pelos dois discursos científicos daria o aval ontológico à realização desse projecto.

\section{A tentativa comteana}

Foi Augusto ComTe (1798-1857) quem, pela primeira vez, procurou sistematizar uma teoria explicativa dos fenómenos sociais. Sem a conjuntura concreta da sociedade francesa produzida por sequelas da Revolução e a posição privilegiada que Augusto COMTE ocupou nos primórdios do seu labor intelectual, não se consegue explicar a emergência de tal projecto no autor do Cours de Philosophie Positive (3).

Como vimos, a postulação da objectividade da realidade social como um todo autónomo e auto-suficiente exigiu a destruição do horizonte ôntico-axiológico medieval. Mas, para que se pudesse encetar um trabalho teórico conducente a essa cientificação, havia ainda que «matar» todas as concepções individualístico-atomísticas da sociedade, já que a possibilidade da sua cientificação implica a existência de relações objectivas, isto é, de regras e de constantes. Portanto, só a credibilidade ou existência de estruturas trans-subjectivas poderia criar a expectativa da apropriação cognitiva da sociedade.

(1) Sobre a importância do conceito de totalidade e de consensus na formação da sociologia, veja-se Georges Gurvitch, Pour le Centenaire de la Mort d'Auguste Comte (1857-1957). - Trois Chapitres d'Histoire de la Sociologie: Auguste Comte - Karl Marx - Herbert Spencer, Paris, C.D.U., 1957, p. 20.

(2) Veja-se A. Comte, Cours, vol. 4, pp. 341-381. Sobre os biólogos que mais influenciaram A. Comte - LoRdat, Barthez, Bichat, Blainville -, veja-se Georges Canguilhem, L'École de Montpellier jugée par Auguste Comte, in «Études d'Histoire et de Philosophie des Sciences», Paris, Librairie Philosophique J. Vrin, $1970^{2}$, pp. 75-80.

(3) Sobre a biografia intelectual de A. Comte, veja-se Henri Gounier, La Vie d'Auguste Comte, Paris, Gallimard, $1931^{5}$. 
Ora, quatro modelos interpretativos apareceram para explicar as sequelas económicas, políticas e ideológicas da Revolução: um, individualista e kantiano, visava justificar o liberalismo tout court; outro, consciente da importância histórica da nova classe gerada pelo industrialismo - o proletariado - , procurava dar uma continuidade qualitativamente diferente ao progressismo burguês; um outro, tradicionalista e reaccionário, apontava para um regresso ao Antigo Regime; e, por fim, havia ainda os que, aceitando, numa óptica conservadora, o valor histórico das conquistas burguesas da Revolução, se esforçavam por interpretar a sociedade de modo a conseguir-se a plena e definitiva consolidação dessas conquistas e evitar-se a eclosão de qualquer revolução futura.

Augusto СомтE veio a situar-se nesta última linha. Isto é, a sua posição de classe, ou melhor, o código de leitura à luz do qual interpretou a realidade social foi o da burguesia conservadora, fracção de classe que, para conquistar a hegemonia económica, política e ideológica, necessitava de instrumentos ideológicos e / ou científicos capazes de justificarem e legitimarem o exercício de um poder altamente centralizado, interventor e repressivo. E esta foi, sem dúvida, a preocupação dominante do trabalho teórico de Augusto Comte (1).

Daqui resulta a situação paradoxal e até ambígua do comtismo. Por um lado, compartilha com muitos dos seus contemporâneos - Saint-Simon, Cabet, Fourier, Proudhon e, até certo ponto, MarX a preocupação intelectual gerada pela conjuntura objectiva decorrente das contradiçoes sociais do capitalismo e que exigia a irrupção da ciência da sociedade; mas, por outro lado, dada a sua posição de classe, ou código de leitura social, o sistema comteano não «verá» para além das aparências (2). Ao contrário, e dentro da tradição empirista, a sua

(1) São as seguintes as principais obras de CомтE: Opuscules de Philosophie Sociale (1819-1828)-encontram-se reproduzidos no fim do $4 .^{\circ}$ tomo do Système de Politique Positive; Cours de Philosophie Positive (1830-1842); Traité Élémentaire de Géométrie Analytique (1843); Traité Philosophique d'Astronomie Populaire (1844); Discours sur l'Esprit Positif (1844); Discours sur l'Ensemble du Positivisme (1847); Système de Politique Positive, ou Traité de Sociologie, instituant la Religion de l'Humanité (1851-1854); Catéchisme Positiviste (1852); Appel aux Conservateurs (1855); Synthèse Subjective, ou Système Universel des conceptions propres à l'état normal de l'Humanité (1856).

(2) «La science constitue toujours un simple prolongement de la commune sagesse. Jamais elle ne crée réellement aucune doctrine essentielle. Les théories se bornent à généraliser et à coordonner les aperçus empiriques de la raison universelle, 
Sociologia buscará ser tão-só a sistematização das explicações do senso comum e a rejeição de todas as concepç̃es contestatárias da sociedade capitalista (1). Assim, em nome do cientismo, Augusto Comte procurou justificar e re-conhecer na teoria o interesse da grande burguesia e, ao mesmo tempo, recalcar as lutas sociais, integrando as classes trabalhadoras no sistema capitalista ${ }^{(1)}$.

Diga-se que o autor do Cours ocupou uma situação privilegiada para a realização de tal projecto. Discípulo e secretário de SAINT-SıMON, assistiu empenhadamente aos esforços deste tendentes a criar uma nova ciência, a que deu o nome de Fisiologia Social (2). Com efeito, SAINT-SimON, seguindo um modelo de interpretação biologista, inspirado nos estudos de Vice D'Azyr, Bichat, Blainville e Cabanis, tentou esboçar as leis da sociedade à luz dessa analogia.

Sem nos determos no valor sociológico desta tentativa - para Durkheim, Maxime Leroy e Gurvitch, SAINT-Simon é o verdadeiro fundador da Sociologia $\left({ }^{3}\right)$ - interessa assinalar que todo o trabalho teórico saintsimoniano teve como motivação dominante os problemas sociais produzidos pela chamada revolução industrial burguesa. Tentou regenerá-los mediante uma filosofia baseada na ética do Amor, que, a seus olhos, aparecia como a única via capaz de edificar uma sociedade assente no desenvolvimento técnico e na harmonia das classes. No entanto, essa sociedade só seria possível desde que se melhorasse a existência moral e económica da classe mais numerosa e mais pobre - o proletariado industrial.

Evidentemente que a forma pouco sistemática e flutuante como

afin de leur procurer une consistance et un développement qu'ils ne pourraient autrement acquérir» (А. СомтE, Catéchisme Positiviste, Paris, Garnier-Flammarion, 1966, p. 133). Veja-se também Pierre DuCAssé, Essai sur les Origines Intuitives du Positivisme, Paris,Félix Alcan, 1939, p. 51.

(1) Sobre as ligações entre as ideologias teóricas empíricas em ciências sociais e os interesses da classe dominante, veja-se Manuel Castells, Epistemologia $e$ Ciências Sociais, Porto, Afrontamento, 1975, pp. 29-34. Por outro lado, uma crítica pertinente à concepção que pretende reduzir a teoria a um simples prolongamento do senso comum encontra-se em A. Gramsci, Il Materialismo Storico, Roma, Editori Riuniti, 1971, pp. 6 e ss..

(2) Sobre a sociologia de SAINT-Simon e as suas ligações com o pensamento de A. Сомte, veja-se Georges Gurvitch, Les Fondateurs Français de la Sociologie Contemporaine, I-Saint-Simon: Sociologue, Paris, C.D.U., 1955.

(3) Idem, pp. 7 e 12. 
SAINT-Simon elaborou o seu ideário e as mutações estruturais que ocorreram depois da sua morte (1825) produziram várias interpretações sobre o significado da sua obra. Assim, enquanto MARX e ENGELS o definiram como um socialista utópico, e Proudhon se esforçou por dar continuidade ao seu ideário reformista, os discípulos mais directos - Péreire, Bazard, Enfantin, Rodrigues, Michel Chevalier, BarRAULT - tenderam para uma interpretação marcadamente tecnocrática e capitalista dos propósitos saint-simonianos (1).

Qual a atitude de Augusto Comte perante a obra do seu antigo mestre? A pretexto de querelas ligadas à publicação dos primeiros opúsculos de ComTe, cedo este se desligou de SAINT-Simon e, embora em toda a sua obra posterior se denote uma evidente influência saintsimoniana, ainda que em sentido conservador, as pretensões de novidade do autor do Cours levaram-no a denegrir e a recalcar essa presença nos seus escritos. Por isso, no Système de Politique Positive, СомтE lastima-se da «.... funeste liaison de ma première jeunesse avec un jongleur dépravé [SAINT-SimON]», sustentando «qu'une telle liaison n'avait comporté d'autre résultat que d'entraver mes méditations spontanées, antérieurement guidées par Condorcet» (2).

Esta distanciação compreende-se. É que, ao pender para uma visão conservadora do mundo social, Augusto COMTE apercebeu-se de que a dimensão reformadora do pensamento de SAINT-Simon era incompatível com uma concepção sociológica de vocação conservadora, pois não se adequava por inteiro a uma doutrina que visava defender os interesses ideológicos da burguesia na fase de consolidação do poder económico, político e ideológico. Para isso, havia que demonstrar

(1) Sobre os continuadores directos de SAINT-Simon, veja-se SÉbastien CharLÉTY, Histoire du Saint-Simonisme (1825-1864), Paris, Éditions Gauthier, 1964.

(2) А. Сомте, Systeme de Politique Positive, Paris, Librairie Philosophique de Ladrange, 1852 t. III, p. XV e XVI. Curiosamente, os positivistas portugueses não aderiram a esta versão sobre as origens do comtismo. Assim, um deles escrevia em 1881: «Na primeira fase do saintsimonismo teve origem a filosofia de Comte; foi ali que ele bebeu as ideias primordiais que servem de base à Filosofia Positiva, tais como: a lei de três estados e a hierarquia científica. Cremos que as doutrinas saintsimonianas contribuiram não só para a fundação do positivismo como para a política industrial e para a religião da humanidade» (TeIXeIra BASTOS, Comte $e o$ Positivismo, Lisboa, Nova Livraria Internacional, 1881, p. 34). 
não só o naturalismo desse domínio, como conferir-lhe um estatuto «científico». Para CoMte isso seria possível na medida em que, depois da plena cientificação da Física, da Química e sobretudo da Biologia, o espírito humano teria a capacidade de se apropriar cognitivamente dos fenómenos mais complexos da esfera do Ser - os fenómenos sociais, já que, com a entrada na fase positiva, completar-se-ia a explicação científica de todos os graus da realidade e anular-se-iam as explicações produzidas quer pela concepção teológica, quer pelas teorias metafísicas. Nem transcendência deísta, nem imanência metafísica. O único saber válido seria aquele que, seguindo o modelo das ciências da natureza - a observação, a experiência e o raciocínio -, abandonaria a inquirição do porquê das coisas e limitar-se-ia à indagação relacionadora, ao como do seu acontecer (1). Isto é, Augusto ComTe pensava que a Humanidade - pelo menos a sua vanguarda europeia - estava apta a aplicar a metodologia científica aos fenómenos que, devido à sua complexidade máxima e mínima generalidade $\left({ }^{2}\right)$, tinham até aí recebido explicações ou de carácter teológico - as teorias providencialistas e jusdivinistas - , ou de inspiração metafísica - as doutrinas contratualistas e socialistas (3). Para ComTe, posta de lado a economia política, essa ciência só poderia ser a sociologia (4).

A nova ciência, recorrendo à metodologia das ciências da natureza - ainda que acrescentada com a utilização do método comparativo e do método histórico e reivindicando, por isso, uma certa especificidade $(5)-$, teria o mesmo grau de objectividade e de neutralidade que,

(1) А. Сомте, Cours, vol. 4, pp. 295-296.

(2) Como se sabe, a ontologia comteana assentava numa hierarquização do Ser que variava segundo a ordem apontada. Sobre este assunto, veja-se A. ComTE, Cours, vol. 1, pp. 19, 47 e ss..

(3) Como veremos, A. Comte esforçou-se por demonstrar a inocuidade teórica em que assentavam quer os regimes monárquicos, quer a democracia formal burguesa, quer as propostas socialistas e comunistas. Por isso criticou os seus fundamentos. Veja-se A. Comte, Cours, vol. 4, pp. 22, 34, 81; vol. 5, p. 215; vol. 6, p. 228, e Système, t. II, pp. XIII-XXI.

(4) Sobre a emergência do conceito de «sociologia» em Comte, veja-se PIERre Arnaud, Pour Connaitre la Pensée de A. Comte, Paris, Éd. Bordas, 1969, pp. 119-148.

(5) A metodologia comteana pode resumir-se neste princípio, directamente deduzido da sua ontologia: «... la série encyclopédique indique à la fois la marche nécessaire de l'éducation théorique et l'essor graduel du vrai raisonnement. Principalement déductive dans son berceau mathématique, où les inductions indispensables sont presque toujours spontanées, la méthode positive devient de plus inductive à mesure qu'elle aborde des spéculations plus éminentes. Dans cette longue éla- 
ao nível do funcionamento da ilusão ideológico-cientista, colocava os seus resultados para além de quaisquer conotações de ordem classista (1).

Uma leitura vigilante deste projecto teórico revela as intenções de classe que comandaram a sistematização do discurso cientista comteano. Com efeito, é sabido que qualquer ciência, para se formar, exige uma especificidade conceptual e metodológica imposta pela autonomia do seu objecto teórico e pela natureza concreta da realidade por ela referenciada, bem como a definição de um preciso critério de verificação da verdade das suas conclusões, auto-suficiente e sem postulados de carácter extra-científico. Ora, o discurso comteano não só atropela as primeiras exigências (os seus conceitos e métodos são decalcados de outros campos científicos, e isto apesar do apelo ao método comparativo e histórico), como o critério fundante do sistema científico remete para uma forma de explicação da realidade que a sua Sociologia visava invalidar: a filosofia metafísica.

boration, il faut distinguer quatre degrés essentiels, où la complication croissante des phénomènes nous fait successivement développer l'observation, l'expérience, la comparaison, et la filiation historique. Chacune de ces cinq phases logiques, y compris le début matémathique, absorbe spontanément toutes les précédentes, d'après la subordination naturelle des phénomènes correspondants. La saine logique devient ainsi complète, et dès lors systématique, aussitôt que l'essor décisif de la sociologie fait surgir la méthode historique, comme la biologie avait auparavant institué l'art comparatif, après que la physique eut assez développé l'observation et l'expérience» (А. Сомте, Catéchisme Positiviste, p. 102). Sobre a especificidade da Sociologia no conjunto da taxinomia de Comte, veja-se também GEORGES GUSDORF, op. cit., pp. 350-353.

(1) GeORges GuSDORF assinala uma diferença entre comtismo e cientismo, pois, segundo ele, as características típicas do cientismo (explicação do superior pelo inferior e diluição do conhecimento filosófico no conhecimento científico) não se encontrariam no ideário do autor do Cours. O cientismo seria uma doutrina pós-comteana, desenvolvida por seguidores que não teriam compreendido o essencial da doutrina do mestre. Mas, se alguns dos juizos de GuSDORF nos parecem pertinentes, pensamos, no entanto, que esta sua análise recalca o significado último do comtismo. Com efeito, quer a epistemologia de Comte, quer o papel que atribuiu à filosofia (simples discurso genérico sobre as práticas científicas) estão imbuídos de um ideal cientista. Mesmo no período da teorização da Religião da Humanidade, ainda que apele para uma explicação do inferior pelo superior, mediada pela Moral, é ainda a ciência naturalista (a própria Moral seria uma ciência natural) que surge como critério de verdade. Por isso, para nós, o comtismo é uma corrente particular inserida no horizonte cientista do século XIX. Cf. G. GuSDORF, op. cit., pp. 348 e ss.. 
De facto, o edifício epistemológico de COMTE acabava por basear-se numa ontologia de raíz metafísica, pois, por um lado, a realidade objectiva era definida segundo uma hierarquia ôntica em que os vários graus do ser, ou melhor, os fenómenos, estavam escalonados numa ordem que partia dos fenómenos mais gerais e menos complexos (os fenómenos matemáticos) e culminava nos mais complexos e menos gerais (os fenómenos sociológicos). A esta graduação do ser correspondia uma concomitante evolução do espírito no sentido da apropriação cognitiva da realidade. Por conseguinte, havia uma adequação entre a ontologia, a lógica e a história. Isto é, a evolução do espírito caminhava para a plena positividade através da crescente cientificação das esferas do ser numa ordem histórica que ia das ciências mais gerais e menos complexas, a matemática, até à última das ciências, a sociologia.

Por tudo isto, a possibilidade de se edificar a sociologia aparecia como consequência de uma evolução necessária do espírito e do estatuto ôntico da realidade social. Portanto, a validade dos seus alicerces enraizava-se na "verdade» dos seus fundamentos. Ora, se é discutível a explicação do aparecimento da problemática das ciências sociais em termos de complexidade fenoménica - ao contrário, é à luz da conjuntura epistemológica produzida pelas contradições do modo de produção capitalista que essas razões têm de ser encontradas -, muito mais controversa é a fundamentação desse necessitarismo em termos de uma filosofia do espírito que, apesar das declarações de positividade, assumia uma declarada dimensão teleológica. Com efeito, por um lado, a capacidade que teria o espírito humano de cientificar os fenómenos e, em particular, os fenómenos sociais, estaria dependente da sua desenvolução, isto é, da ultrapassagem da fase teológica e metafísica; mas, por outro lado, esta lei fundante das ciências e, portanto, da sociologia, era ela mesma uma conclusão da análise científica da dimensão diacrónica dos fenómenos sociais. Assim, das duas uma: ou o projecto sociológico era verdadeiro porque era válida a lei dos três estados, ou, pelo contrário, a lei dos três estados era verdadeira porque as conclusões da análise sociológica seriam válidas. Os fundamentos epistemológicos do comtismo caíam, portanto, num círculo vicioso que, diga-se, foi comum a outros projectos sistematizadores das ciências assentes em critérios idealistas (HEGEL) (1).

(1) Cf. Jean Lacroix, op. cit., pp. 56-57. 
Deste modo, falta à Sociologia comteana a autonomia dos conceitos, dos métodos e dos critérios de verificação que caracterizam as ciências verdadeiramente constituídas. Daí que a sua tentativa tenha mais a ver com a intenção de se estruturar uma ideologia teórica que, em nome da força convincente do cientismo, justificasse e encobrisse interesses de classe bem precisos, do que com a construção de uma ciência. Em última análise, sendo uma teorização pautada por uma filosofia idealista que se traduzia numa atitude empírica perante o problema do conhecimento, o comtismo elevou a um nível doutrinal as explicações do senso comum produzidas pelas representações espontâneas da classe dominante. Dir-se-ia que Augusto Comte, longe de ser o primeiro dos sociólogos, foi um dos últimos filósofos idealistas que procurou enroupar numa ganga mística a autonomia e a materialidade da ciência da sociedade, cuja emergência no espaço epistemológico era necessitada pela conjuntura económica, política e ideológica do século XIX.

Assim se explicam as formas concretas que as sociedades humanas assumiram durante o seu evoluir, bem como o motor desta mesma mobilidade, nada tivessem a ver com as relações materiais que os indivíduos mantinham entre si e com a natureza, nem com a motricidade decorrente dessas relações (1). Ao contrário, a mobilidade social não passava de uma mera consequência fenoménica, cuja causa determinante estava na evolução espontânea do espírito (2). Portanto, a cada fase espiritual da Humanidade corresponderia uma forma sociopolítica dominante - ex.: a fase teológica monoteística determinava o regime feudal-militarista, o espírito metafísico produzia os

(1) «Ce n'est pas aux lecteurs de cet ouvrage que je croiral jamais devoir prouver que les idées gouvernent et bouleversent le monde, ou, en d'autres termes, que tout le mécanisme social repose finalement sur des opinions. Ils savent surtout que la grande crise politique et morale des sociétés actuelles tient, en dernière analyse, à l'anarchie intellectuelle. Notre mal le plus grave consiste, en effet, dans cette profonde divergence qui existe maintenant entre tous les esprits relativement à toutes les maximes fondamentales dont la fixité est la première condition d'un véritable ordre social» (A. ComTE, Cours, vol. 1, pp. 40-41). Consequentemente, ao contrário das tentativas de alguns, a sociologia comteana encontra-se nos antípodas de uma explicação materialista da história. Cf. R. PAula LoPes, Auguste Comte et la Lutte de Classes, in "Les Études Philosophiques», n. ${ }^{\circ}$ 3, Juillet-Septembre, Paris, P.U.F., 1974, pp. 355-366.

(2) Como se sabe, a expressão cientista deste idealismo é a célebre lei dos três estados. 
regimes revolucionários e a fase positiva deveria gerar as formas científico-industriais de organização político-social (1).

Mas, onde a conotação classista do discurso de Augusto ComTe aparece com mais explicitude é ao nível da sua estática social. A ilusão eternalista típica da compreensão histórica da burguesia oitocentista triunfante nota-se com toda a evidência. Com efeito, o tempo social não era apresentado como uma consequência da motricidade decorrente da luta das forças sociais entre si, mas tão-só como uma desenvolução de algo fixo. Por outras palavras, o dinamismo social mais não era do que a concretização do estático e, por conseguinte, o progresso só podia ser o desenvolvimento da ordem (2). Assim, Augusto ComTe aceitava a historicidade dos fenómenos sociais para melhor vincar a perenidade das relações e estruturas que procurava defender: o estado, a família monogâmica e patriarcal e a propriedade privada (3).

$\mathrm{Na}$ verdade, é a partir da sua estática que Augusto CомтE fundamenta a propriedade privada dos meios de produção, que considerava uma necessidade material para o desenvolvimento intelectual e moral dos organismos sociais (4). No entanto, a dimensão e a função da propriedade que tinha em mente não era a pequena propriedade do capitalismo liberal. É que A. Comte procurava ser um teórico do capitalismo bancário e industrial, apelando não só para o seu dimensionamento, como para a ultrapassagem do conceito romanista do jus utendi, fruendi et abutendi (5). O capitalismo que defendia era o da fase pós-concor-

(1) Cf. A. Comte, Cours, vol. 4, pp. 22, 34, 81; vol. 5, pp. 204, 278, 282, 398, 403, 447, 509; vol. 6, pp. 347-349, 481 e ss..

(2) «Le progrès est le développement de l'ordre» (A. ComtE, Système, t. I, p. 493). Com efeito, se no Cours ainda é possível uma leitura que fundamente a prioridade da dinâmica sobre a estática na sociologia de ComTe, uma leitura do Système dissipa todas as dúvidas. A quase totalidade da obra diz respeito à explicitação dos princípios da estática e da ordem.

(3) Uma sistematização, com os textos fundamentais, do pensamento politico de A. Comte, encontra-se em Pierre Arnaud, Politique d'Auguste Comte, Paris, Armand Colin, 1965.

(4) «.... la richesse matérielle ne comporte une haute efficacité, surtout sociale, que d'après un degré de concentration ordinairement supérieur à celui qui peut jamais résulter de la simple accumulation des produits sucessifs du seul travail individuel» (A. CoмTE, Système, t. II, p. 154); veja-se também pp. 149-172, 217-218 e Cours, vol. 4, pp. 201 e ss.

(5) Idem, pp. 412-413, 420. 
rencial, isto é, do período em que o Estado tinha de influir directamente na economia. E, se ComTe não chegou a fazer a apologia de um intervencionismo capitalisticamente participante, reivindicou para $o$ Estado o papel de vigia e interventor sobre as propriedades que não desempenhassem uma função social produtiva.

Teórico dos interesses do grande capitalismo e escrevendo sob o impacto da agudização da luta de classes - COMTE ficou traumatizado com as revoltas proletárias de Lyon, na década de trinta $\left({ }^{1}\right)$ - teve de perspectivar a questão do poder político em oposição radical com as teses do democratismo formal. Por isso, não conferiu qualquer valor às doutrinas contratualistas, fundantes da soberania popular e do sufrágio universal, as quais, a seus olhos, não passavam de concepções metafísicas que a evolução do espírito humano em sentido positivista tinha definitivamente ultrapassado (2). Se no período da sua necessidade tinham destruído, com proveito para a evolução da Humanidade, o espírito teológico, a sua sobrevivência era nociva, na medida em que assentavam num individualismo extremo onde o homem, definido como um sujeito portador de livre vontade, surgia elevado à categoria de Deus na terra. Portanto, sendo um anti-individualista convicto, Augusto Сомте pugnou, principalmente no Système de Politique Positive, por um poder político legitimado em termos de capacidade científica e industrial, devendo o poder espiritual pertencer aos portadores do saber: os filósofos positivistas ${ }^{3}$ ). Seguindo estrutural e formalmente o modelo medieval, ComTE atribuía a este poder a supremacia sobre os negócios temporais. Assim, a filosofia positiva, ou melhor, a Sociologia, aparecia como o guia espiritual e ideológico da opinião pública na sociedade industrial.

É, contudo, ao nível do poder temporal que a dimensão classista do discurso comteano emerge com toda a evidência. $\mathrm{Na}$ verdade, o regime político que propunha devia passar por um período de tran-

(1) Veja-se A. Сомте, op. cit., t. II, pp. XIII, XVI, XXIX.

(2) Veja-se A. Cомте, Cours, vol. 5, pp. 525-527; Système, t. 1, pp. 611-622; t. II, p. XXVII, 180-181, 191-192; t. III, pp. XII, XXIX, 596-601, 611-613.

(3) Veja-se A. Cомтe, Cours, vol. 6, pp. 445 e ss.. O Système e o Catéchisme mais não são do que obras em que se fundamenta e sistematiza, do ponto de vista de organização, esta mesma ideia. Sobre o conceito de legitimidade em Augusto Comte, veja-se Pierre Arnaud, L'Idée de Légitimé dans la "Nouvelle Philosophie Politique» d'Auguste Comte, in "Annales de Philosophie Politique», n. ${ }^{\circ}$ 7, Paris, P.U.F., 1967, pp. 195-210. 
sição em que o poder pertenceria a um grupo de proletários, para depois se solidificar definitivamente num regime republicano governado pelo capitalismo bancário (1).

Coerentemente, o modelo de Estado que se adequava à prossecução dos interesses do grande capitalismo não podia ser de tipo liberal. Deste modo, Augusto ComTe apelava para um estado forte, centralizado, intervencionista e ditatorial. $\mathrm{O}$ seu ideal político resumia-se nesta fórmula : - «concilier irrévocablement la dictature et la liberté, suivant le væı systématique de Hobbes, spontanément réalisé par Frédéric» (2). Compreende-se, assim, que inicialmente tivesse apoiado Luís Napoleão (3) e que, quanto à questão das liberdades formais, só respeitasse o direito de expressão, pois estava convencido de que a força demonstrativa da sua ciência conseguiria criar uma opinião pública consensualizada através da livre discussão (4).

Estado forte e ideologia uniformizada eram as propostas fundamentais que COMTE oferecia à grande burguesia, a fim desta implantar um regime que evitasse quer as querelas entre as fracçðes e camadas burguesas, quer as revoluções de inspiração socialista. Por isso, havia que definir a sociedade como uma totalidade que invalidasse simultaneamente o estatuto ôntico e axiológico do indivíduo e a homogeneização comunitária ou colectivista do ser social. Para CоMTE, o indivíduo, enquanto átomo social, não passava de uma abstracção metafísica. Nos graus do ser social, em primeiro lugar encontrava-se a família, tecido básico da sociedade (5). Deste modo, o consensus social era somente o resultante do funcionamento coordenado das partes que, sujeitas à divisão orgânica do trabalho, eram sobredeterminadas pelo princípio da totalidade.

A esta luz, compreende-se também que a diluição anarquista do estado e a absorção das regiões sociais fossem rejeitadas por COMTE.

(1) Veja-se A. Comte, Systeme, t. III, pp. 602 e ss.; t. IV, pp. 345-350. Cf. Pierre Arnaud, La Politique d'Auguste Comte, pp. 298-301.

(2) А. Сомте, Système, t. IV, p. 378.

(3) Idem, t. II, p. XXVI.

(4) Idem, t. III, p. 602.

(5) «La société humaine se compose de familles, et non d'individus» (A. Cомте, Système, t. II, p. 181). Veja-se também Cours, vol. 4, p. 398; Système, t. III, pp. 139 e ss., 180 e ss.. Cf. Pierre Arnaud, op. cit., pp. 125-152. 
A prioridade do todo não devia subsumir as partes, mas ser uma condição política para o seu pleno desenvolvimento (1).

Mas, se este modelo organicista permitia justificar a necessidade de um estado forte, sem com isso apelar para a «morte» dos organismos regionais, e se, por outro lado, permitia apelar para uma entidade superior onde todos os estados se inseriam - a Humanidade -, foi no plano da ideologia que Augusto ComTE colocou a tónica da sua doutrinação em prol da hegemonização consensual da sociedade capitalista. E o modo como o fez não deixa de revelar a inquietude de uma classe que estava consciente da decadência e da inadequação da mundividência católico-feudal face às exigências do capitalismo, mas sentia também que só uma forma religiosa podia preencher os requisitos necessários ao domínio político de uma classe conservadora (2).

Compreende-se facilmente que, de acordo com a sua filosofia da história e com a consciência que tinha da importância da ideologia na unificação das contradições sociais, a ética altruística e cientista das suas primeiras obras tenha dado lugar a uma nova religião ( $\left.{ }^{3}\right)$. Assim, se no Cours encontramos uma atitude intelectualista a fundamentar tão-só uma ética altruísta e laica, no Système e no Catéchisme os preceitos éticos são veiculados através de uma dogmatização e ritualização expressas na Religião da Humanidade e são justificados por uma teoria do conhecimento que dá prioridade ao sentimento sobre a razão (4) e à moral sobre a sociologia (5). Deste modo, a preocupação de regeneração social em CoMTE veio desaguar numa religião que, tanto do ponto de vista formal como funcional, era decalcada do

(1) Devido a tal concepção, todas as obras de CoMTE estão cheias de acusações ao individualismo, ao socialismo e ao comunismo utópico.

(2) É interessante notar que, em muitos teóricos oitocentistas, a consciência da inadequação da ideologia católico-feudal às necessidades decorrentes das contradições nascidas no seio da sociedade industrial foram pensadas em termos ainda religiosos. Daí as tentativas explícitas da fundação de uma nova religião (SAINT-Simon, CABEt, ComTE), a problematização da realidade social em termos de divinização do homem (Feuerbach, jovem MARX), ou a divinização do conceito ético-jurídico (PROUdHON).

(3) A teorização deste ideal religioso encontra-se sobretudo no Système (tomos II, III e IV). No Catéchisme Positiviste assume uma forma dialógica e catequética.

(4) Veja-se A. Cомте, Catéchisme, pp. 42-43.

(5) Veja-se A. Сомте, Systeme, t. II, p. 265. 
catolicismo medieval (1). Distanciava-se dela somente ao nível do conteúdo: deificava-se a Humanidade, a hagiografia era constituída pelos grandes homens que pelo seu pensamento ou acção contribuiram para o aperfeiçoamento civilizacional, o novo calendário assinalava os grandes momentos da história e aos padres sucederiam os filósofos positivistas (2). Por outro lado, sendo a Humanidade formada pelos povos do passado, do presente e do futuro, o novo Deus seria simultaneamente imanentista e transcendente, conforme fosse explicado em termos de contemporaneidade ou não. Consequentemente, dada a sua onticidade, passivel de ser observada e sentida, a religião de Comte teria o estatuto de uma religião demonstrada $\left(^{(3)}\right.$.

Com tal argumentação pensava o autor do Cours que, de uma vez por todas, a Humanidade tinha alcançado um corpo científico-religioso definitivo, capaz de regenerar e consensualizar os sentimentos e a razão do homem moderno $\left.{ }^{4}\right)$. Dir-se-ia que a religião positivista mais não era do que a forma popular e catequética de fazer chegar as conclusões gerais da ciência às massas populares $\left(^{5}\right)$. Ora, sabendo-se que esta sociolatria assentava numa sociocracia ao nivel espiritual, vê-se desde logo o papel fundamental desta religião no funcionamento da sociedade. A nova Igreja teria como missão reproduzir, em termos de opinião pública, as conclusões contidas no sistema sociológico comteano. Para isso, A. Сомте propunha dois coadjuvadores: a mulher e o proletariado.

A mulher seria um óptimo propagador popular do ideal positivista dada a sua natural tendência para pôr o coração a comandar a razão

(1) Veja-se А. Сомте, Idem, pp. 336 e ss..

(2) Para a exposição das ideias religiosas de CoмTE, vejam-se, para além das duas obras atrás citadas, as de ANGèle Kremer-Marietti, Auguste Comte, Éd. Seghers, Paris, 1970; Jean Laubier, Auguste Comte - Sociologie, Paris, P.U.F., 1965; Pierre Arnaud, Le «Nouveau Dieu»-Préliminaires à la Politique Positive. Uma exposição perspectivada dessa religião, mas inserida no contexto da crise ideológico-religiosa do século XIX, veja-se em HenRI DE LUBAC, S. J., O Drama do Humanismo Ateu, Porto, Porto Editora, s. d., pp. 133-278.

(3) Veja-se A. Сомте, Système, t. II, pp. 59 e ss.

(4) «....la religion se rapporte à la fois au raisonnement et au sentiment, dont chacun serait isolément impropre à établir une véritable unité, individuelle ou collective» (А. Cомте, Systeme, t. II, pp. 11-2); veja-se também t. II, pp. 307-308.

(5) Veja-se A. CомтE, Système, t. II pp. 307-308, 312-315, 322. Sobre a explicação do dogma e as formas do culto (privado e público) e do regime (privado e público), veja-se, principalmente, o Catéchisme. 
e, assim, influenciar não só o marido, mas os filhos através da educação doméstica (1); por sua vez, o proletariado, dada a sua situação objectiva no processo de trabalho, criadora de um altruísmo espontâneo decorrente do facto de trabalhar para outrem, seria facilmente convertido a um ideal de conciliação de classes e às expectativas ecuménicas exigidas pela evolução da Humanidade (2).

Não entrando na polémica acerca da existência de uma ruptura entre o Comte do Cours e o do Système, contudo, parece-nos indiscutível ter existido uma evolução na problemática dominante nas duas obras. Assim, é um facto que o teor do Cours se pode caracterizar por uma atitude intelectualista face ao conhecimento da realidade natural e social e por um domínio da problemática ligada à fundamentação de uma teoria dinâmica da sociedade capaz de justificar a inevitabilidade de um progresso assente numa ordem económica e política capitalista ideologicamente secularizada. Todavia, no Système, Augusto Comte, sem negar o essencial do Cours, regressa a um pensamento quase fetichista, privilegiando as questões ligadas ao estatismo social e ao ideologismo religioso (3).

Radica nesta diferença o destino da obra de Comte. Como se sabe, logo após a sua morte, os discípulos dividiam-se em duas escolas diferentes. Uma, a de LAFFITTE, aceitou-a como um todo e procurou

(1) Para COMTE, as mulheres seriam «Supérieures par l'amour, mieux disposées à toujours subordonner au sentiment l'intelligence et l'activité, les femmes constituent spontanément des êtres intermédiaires entre l'Humanité et les hommes»" (A. Сомте, Système, t. II, p. 63); veja-se também pp. 311-312 e ainda Catéchisme, pp. 44 e ss..

(2) «....les graves perturbations que l'anarchie moderne développa de plus en plus, de parte et d'autre, ne sont aucunement inhérentes à la nature de notre existence pratique, et n'y résultent que du défaut de systématisation mentale et morale» (A. Сомте, Système, t. II, p. 399). O ideal de harmonia social, conseguido através da mediação religiosa e da hegemonia política dos banqueiros, era resumido por CомтE nos seguinte termos: «Le patriciat industriel, devenu plus digne et mieux respecté, se sentira voué directement à l'incomparable félicité résultée d'une activité soutenue des trois instincts sociaux, l'attachement au sexe affectif, la vénération pour le sacerdoce, et la bonté envers le prolétariat» (Idem, p. 404); veja-se também pp. 411-413.

(3) Sobre a atitude fetichista do pensamento de CoMTE, veja-se o artigo de G. Canguilhem, Histoire des Religions et Histoire des Sciences dans la Théorie du Fétichisme chez A. Comte, in Georges Canguilhem, «op. cit.», pp. 81-98. 
fazer reviver o positivismo religioso; a outra, chefiada por LITTRÉ, ateve-se ao essencial do Cours e relegou para o campo da degenerescência mental as últimas obras do mestre (1).

Aqui interessa-nos particularmente este último movimento, na medida em que foi através dele que o comtismo penetrou no nosso país. Que espécie de leitura fez esta escola dos textos de ComTE? Em síntese, pode dizer-se que tomaram uma atitude heterodoxa e menos reaccionária face a alguns dos princípios mais controversos do ideário comteano (2). Assim, não punham em dúvida nem a validade da lei dos três estados, nem a teoria do conhecimento positivista, nem o essencial da sua taxinomia e da sua sociologia. Rejeitavam a dimensão religiosa do positivismo e punham o acento tónico na ética altruística, quase maçónica (3), na paideia cientista que o comtismo, inegavelmente, transportava.

No entanto, o momento em que escreveram - o grande período criador de LitTré deu-se entre a década de quarenta e a de setenta tinha trazido modificações importantes no campo científico e no terreno social, necessariamente influentes numa filosofia que queria fundamentar um sistema político à luz da ciência, isto é, numa doutrina que queria ser simultaneamente uma filosofia das ciências e uma filosofia político-social.

(1) Um testemunho antigo desta querela entre as duas escolas encontra-se em R. P. Gruber, S. J., Le Positivisme depuis Comte jusqu'a nos jours, Paris, P. Lethielleux Libraire Éditeur, 1893, pp. 7-155.

(2) A interpretação filosófica littreana do pensamento de COMTE encontra-se exposta no prefácio que escreveu para a reedição do Cours em 1869 . Veja-se E. Litrké, Préface d'un Disciple, in A. Comte, Cours, vol. I, pp. V-L. As mesmas ideias encontram-se desenvolvidas em numerosos artigos que durante as décadas de sessenta-setenta fez inserir na Philosophie Positiviste - Revue, bem como nas suas restantes obras de carácter filosófico: De la Philosophie Positive (1845), Conservation, Révolution, Positivisme (1852, reeditada com importantes modificações autocríticas em 1879), Paroles de Philosophie Positive (1859), Auguste Comte et la Philosophie Positive (1863), Etudes sur les Barbares et le Moyen Age (1867), La Science au point de vue philosophique (1873) e Fragments de philosophie positive et de sociologie (1876).

(3) O encontro entre o eticismo laico e altruísta do positivismo e o ecumenismo filantrópico da maçonaria encontra-se simbolizado na adesão de LITTRÉ à maçonaria, em 1875. Veja-se o discurso que proferiu aquando de sua recepção na loja $L a$ Clémente Amitré, in «Philosophie Positive - Revue», t. XXIII, Juillet-Décembre, 1879, pp. 163-169. 
Com efeito, no terreno científico desenvolveram-se alguns domínios de inequívoca cientificidade: biologia, antropologia darwinista, psicologia, fisiologia, economia, linguística, história, etc. - que o dogmatismo taxinómico comteano não podia abarcar, pois, mesmo para o Comte do Cours, a sociologia era não só a última das ciências, como a única ciência social possível. No entanto, a força da prática científica levou à revisão desse bloqueamento, e a escola de LiTTRÉ, apesar da suspeita do chefe em relação a algumas descobertas científicas (ex.: o darwinismo), teve sensibilidade suficiente para tentar integrar essas ciências na sistemática positivista (1).

Por outro lado, no campo político-social, a hegemonização do grande capital durante o Império radicalizou as classes intermédias. Ora, foi à luz dos interesses específicos desta camada social que LITTRÉ «leu» o positivismo comteano. Isto é, o director da revista Philosophie Positiviste não buscou no comtismo o modelo de estado centralizado e alto burguês defendido no Système. Ao contrário, procurou caldear a sua filosofia da história e o seu racionalismo laico com alguns dos pressupostos do republicanismo burguês, adequando a ideologia positivista às necessidades da luta quer contra o monarquismo e o clericalismo imperial, quer contra o revolucionarismo socialista. Deste modo, inspirando-se no preceito progresso e ordem, LITTRÉ e o seu grupo tentaram justificar um republicanismo moderado, conservador, como ele próprio lhe chamava ( $\left.{ }^{2}\right)$, republicanismo este que veio a ter a sua hora de triunfo durante a III República (3).

É verdade que, como veremos, jamais reconheceram qualquer valor filosófico aos princípios da democracia formal. Mas, o pragmatismo e a consciência de que a fase da política definitiva, anun-

(1) Vejam-se sobretudo os artigos de Guarin De Vitry, Wysonboff, Hector Denis, Clavel, E. de Roberty, Blignières, Nuytz, E. Jourdy, Clement Royer, POMPÈry, E. BourdeT, espalhados pela revista de LiTTRÉ.

(2) A obra que melhor consigna o pensamento político de LITTRÉ é a sua Conservation, Révolution et Positivisme, Paris, Libraire Philosophique de Ladrange, 1852. Sobre a vida intelectual e política de LitrRÉ, veja-se Alain Rey, Littré - L'Humaniste et les Mots, Paris, Gallimard, 1970.

(3) Veja-se LitrRé, De l'Établissement de la Troisième République, Paris, Bureau de la Philosophie Positive, 1880. Sobre a influência do positivismo durante as primeiras duas décadas da III República, veja-se LouIs LEGRAND, L'Influence $d u$ Positivisme dans l'Oeuvre Scolaire de Jules Ferry, Paris, Libraire Marcel Rivière, 1961. 
ciada pelo cientismo comteano, estava longe, levaram a que aderissem ao jogo demo-republicano.

Este acasalamento do positivismo com o democratismo burguês teve ainda um outro factor importante: a influência das obras de STUART Mill e sobretudo de SPEnCER. Com efeito, o ideário do positivismo inglês, levando às últimas consequências o super-organicismo positivista, não se deixava cair, no entanto, no estatismo comteano. Ao contrário, na boa tradição burguesa britânica, não subsumiu a realidade individual (1) e, do ponto de vista teórico, mostrou-se muito receptivo às novas descobertas científicas, vindo assim a desbloquear ainda mais a ortodoxia do fundador da filosofia positivista (2).

\section{A conjuntura portuguesa}

A penetração do positivismo em Portugal e, por conseguinte, da sociologia foi um fenómeno típico de importação cultural e a rapidez da sua propagação indica que a doutrina encontrou um húmus social que a exigia. Daí a necessidade de se indagar quais as razões deste sucesso e analisar a forma específica que assumiu a sua inserção na realidade portuguesa.

Ora, é um facto que o positivismo, ou melhor, a Sociologia nasceu para dar uma resposta global e recuperadora à crise económica, política e ideológica do capitalismo. Consequentemente, o seu projecto visava obter uma regeneração dessa crise através da salvaguarda dos valores fundamentais da sociedade burguesa. Assim se explica que, em Portugal, fosse necessário o aparecimento de crises ligadas não tanto à luta contra o Antigo Regime, mas ao próprio desenvolvimento capitalista, para se produzir a conjuntura socioeconómica que levasse à necessidade de se estudar cientificamente os fenómenos sociais. O seu tardio aparecimento - década de sessenta — é já um reflexo do lento

(1) Para comprovar esta asserção basta levar em conta o que SPENCER expõe nos Primeiros Princípios, na Introdução à Sociologia e na sua obra $O$ Individuo contra o Estado.

(2) Sobre este positivismo, veja-se Gruber, op. cit., pp. 228-269. Quanto ao organicismo spenceriano e ao seu contributo para a consolidação do discurso sociológico, veja-se Georges Gurvitch, Pour le Centenaire de la Mort d'Auguste Comte - Trois Chapitres d'Histoire de la Sociologie: Auguste Comte - Karl Marx - Herbert Spencer, pp. 93-103. 
desenvolvimento das forças produtivas em sentido industrialista, pois o nosso processo de hegemonização das novas relações de produção foi lento, e só sob os efeitos da Regeneração se começaram a operar algumas transformações sociais conducentes às primeiras vivências políticas e ideológicas típicas das sociedades industrializadas.

Com a derrota da ala mais progressista do liberalismo, no saldo das guerras da Patuleia, o poder político da monarquia constitucional ficou nas mãos de um bloco social basicamente constituído pela alta burguesia bancária e comercial e pelos grandes senhores agrários beneficiadores da venda dos bens nacionais e da extinção das ordens religiosas. Por conseguinte, a estratégia do seu domínio de classe não assentou numa política desenvolvimentista em sentido industrial. Pelo contrário, procurou-se antes criar um mercado nacional para os produtos agrícolas e, assim, conciliar os interesses dos terratenentes com o capitalismo especulador. As obras de fomento das estruturas rodoviárias e, consequentemente, a animação do capitalismo comercial e das actividades financeiras especuladoras foram o saldo essencial desta política (1).

Ora, do ponto de vista das classes não dominantes, as mutações económicas tinham de produzir os seus efeitos sociais. Assiste-se ao aumento das classes intermédias, ligadas quer à prestação de serviços, quer ao pequeno comércio e às pequenas unidades industriais subsidiárias do desenvolvimento agrícola, grupos sociais esses que, ao entrarem na cena sociopolítica portuguesa, irão lutar pela ocupação de um lugar de chefia no bloco social dominante (2).

É facto que, quando foi lançado o projecto da primeira Regeneração, alguns ideólogos - VIEIRA da Silva, Henriques Nogueira, Sousa BRANDÃo, LoPeS de MENdonça -, escrevendo sob o impacto das ideias socializantes da revolução de 1848 , ainda pensaram ser possível apresentar, como alternativa às pretensões da alta burguesia enobrecida, uma proposta de cariz democrático e republicano. Contudo, sem base social de apoio, o seu pensamento teve um sabor essencialmente denunciador e precursor e mais não conseguiram do que animar

(1) Veja-se Armando de Castro, A Revolução Industrial em Portugal, Lisboa, Publicações Dom Quixote, 1972, pp. 118-134.

(2) Veja-se Joel Serrão, art. Classes Sociais, in «Dicionário de História de Portugal», vol. 1, Lisboa, Iniciativas Editoriais, 1965, pp. 404-406. 
as primeiras sociedades operárias mutualistas e a primeira imprensa socializante. Ora, com o alargamento da pequena burguesia e com as modificações operadas na conjuntura internacional, dir-se-ia que, na década de sessenta, se assistiu ao regresso do ideário da geração de cinquenta $\left({ }^{1}\right)$. De facto, às condições internas veio juntar-se toda uma série de acontecimentos - guerras da Polónia, Itália, fundação da A. I. T., revolução espanhola de 1868 - para os quais a sensibilidade política de um numeroso grupo de intelectuais se encontrava altamente receptiva. Deste modo, a primeira geração integralmente formada depois da vitória liberal começou a ler os acontecimentos nacionais à luz do significado das novas lutas políticas e sociais europeias. Para isso contribuíu grandemente a facilidade de comunicação de ideias trazida pelo desenvolvimento da rede ferroviária que ligou Portugal à Europa (2). Nas obras de autores democráticos - MicheleT, Hegel (Vera), Vico, Proudhon, Renan, Littré, Vacherot, Lamartine, Hugo, Quinet, TAine, Feuerbach, etc. - encontravam os instrumentos doutrinais necessários não só para confirmarem o valor do pensamento dos seus antecessores nacionais - veja-se o artigo elogioso de Antero a Félix Henriques Nogueira - como para criticarem o constitucionalismo regenerador e o seu capitalismo especulador, concentracionista e dependente (3).

A necessidade de se edificar um projecto regenerador, que englobasse os níveis intelectual e moral, económico e político da sociedade portuguesa, instalou-se nos espíritos mais vanguardistas. Compulsando os escritos de Antero, Oliveira Martins, Costa lobo, Manuel Emídio Garcia, José falcão, Teófilo, Eça, Manuel de Arriaga, Anselmo de ANDRADE e outros, independentemente dos pressupostos de fundamentação e até das futuras opções políticas, denota-se a mesma preocupação estrutural. A sociedade passa a ser perspectivada como

(1) Veja-se Antero de Quental, Prosas da Época de Coimbra, Lisboa, Livraria Sá da Costa, 1973, pp. 18-23. Sobre as influências doutrinais do meio coimbrão, veja-se Joaquim de Carvalho, Estudos sobre a Cultura Portuguesa do século XIX, Coimbra, Por Ordem da Universidade, 1955, pp. 52-53.

(2) Sobre a importância das vias de comunicação e o seu impacto na mentalidade portuguesa oitocentista, veja-se Joel SERrão, Das Consequências Nacionais do Advento dos Comboios, in «Temas Oitocentistas», Lisboa, Portugália Editora, 1962, pp. 269-276.

(3) Veja-se Té́filo Braga, Historia das Ideias Republicanas em Portugal, Lisboa, Nova Livraria Internacional, 1880, pp. 107 e ss. 
uma entidade atravessada por crises internas, para cuja superação não serviam medidas sectoriais nem acções conduzidas segundo uma ordem arbitrária. Coerentes com o idealismo filosófico da época, a solução encontrava-se na prévia reforma intelectual e moral da sociedade que, como consequência, traria as necessárias modificações económicas e políticas. Portanto, qualquer projecto regenerador devia basear-se no enquadramento da sociedade portuguesa como um todo, totalidade que se exprimia naquilo que, para eles, era o principal problema do séc. XIX: $a$ questão social.

$O$ aparecimento desta nova necessidade social foi acompanhado por uma correspondente modificação a nível doutrinal. Assim, se o liberalismo tout court se baseava numa filosofia política de inspiração kantiana, a qual postulava uma antropologia atomista, se a monarquia constitucionalista se fundamentava num fluído ecletismo que procurava combinar o individualismo kantiano com resquícios jusdivinistas, se ambas as doutrinas tinham dado provas de não conseguirem harmonizar as contradições da sociedade capitalista, um verdadeiro projecto regenerador tinha que ir contra o individualismo e o racionalismo exagerados de uma e a incoerência doutrinal de outra (1).

Ao contrário, só uma filosofia que, sem abdicar da dimensão racional do indivíduo e da sua onticidade autónoma, fosse capaz de fundamentar o estatuto também autónomo das sociedades intermédias e da sociedade em geral, poderia servir à realização de tal desiderato. Consequentemente, a crítica ao liberalismo extremo e ao constitucionalismo alto-burguês era acompanhada de uma rejeição das filosofias sociais divinistas e atomistas. O pensamento social português abria-se às propostas socializantes e nestas, independentemente das fundamentações, mais idealistas nuns ou mais naturalistas noutros, a sociedade surgia como uma totalidade ôntica, um organismo, em função do qual se explicava o funcionamento das suas partes constituintes.

Evidentemente que este pano de fundo teve variadas formas de concretização, que foram desde o krausismo jurídico e o mutualismo de Rodrigues DE BRITo - filosofia do direito, de base proudhoniana, que tentava contestar o individualismo de Vicente Ferrer Neto

(1) O Prof. Silva Dias estuda profundamente toda a problemática ligada à crítica do individualismo e do racionalismo no seu livro Individualismo e Racionalismo em Portugal (1840-1870), no prelo. 
PaIVA -, até ao proudhonismo-hegelianismo de ANTERo e ao organicismo naturalista (1).

Em todos se nota, todavia, a presença da mesma atitude anti-atomista e a aceitação do funcionamento autónomo e imanentista da sociedade enquanto totalidade «a se» e auto-suficiente.

A expressão sentimental e moral desta nova dimensão social encontra-se na ideia de Humanidade, a qual irrompe com uma atraç̧ão tal que acaba por se impôr como temática dominante no nosso Terceiro Romantismo (2). Assim, compreende-se que EçA retrospective a ambiência destes tempos, escrevendo «...a nossa descoberta suprema foi a da Humanidade. Coimbra de repente teve a visão e a consciência adorável da Humanidade. Que encanto e que orgulho! Começámos logo a amar a Humanidade, como há pouco, no ultra-romantismo, se amara Elvira, vestida de cassa branca ao luar. Por todos os botequins de Coimbra não se celebrou mais senão essa rainha de força e graça, a Humanidade» (3).

(1) Como veremos, o horizonte organicista foi levado às últimas consequências no pensamento positivista. No entanto, pensamos que ele é igualmente detectável, ainda que com uma fundamentação mais idealista, nos pensadores de inspiração proudhoniana. Assim, não se estranha que ANTERo, aliás na linha do pensamento de Oliveira Martins, embora perfilhasse um evolucionismo explicitamente fundamentado em termos metafísicos, escrevesse em 1871: "A sociedade é um organismo, e os organismos transformam-se, não se revolucionam» (ANTERO DE Quental, Prosas, vol. 2, Coimbra, Imprensa da Universidade, 1926, p. 187). Veja-se também pp. 280-1. Por sua vez, o movimento krausista com fervorosos adeptos dentro da Universidade, mais não era do que uma variante dos pensamentos idealistas totalizadores e, por conseguinte, aceitava a dimensão ecuménica e macroscópica da sociedade e da humanidade. Sobre o krausismo em Portugal, veja-se Prof. Silva Dias, Individualismo e Racionalismo em Portugal (1840-1870), no prelo; e Cabral de Moncada, Subsidios para a História da Filosofia do Direito em Portugal, 2. a ed., Coimbra, Coimbra Editora, 1938. Quanto às analogias entre o positivismo e o krausismo, Alfred Fouillé, por exemplo, escrevia em 1880: "Cette idée (que a sociedade é um organismo regido pelas leis da vida) si chère a été aussi très clairement exprimée par KRAUSE, qui y a mêlé d'ailleurs des rêveries métaphysique et théologiques», (A. FouIllé, La Science Sociale Contemporaine, Paris, Libraire Hachette, 1880, p. 78).

(2) Veja-se António SÉrgio, Ensaios, t. I, Lisboa, Clássicos Sá da Costa, 1971, pp. 18, 55 e ss.; Alberto Ferreira, Perspectivas do Romantismo Português, Lisboa, Edições 70, 1971, pp. 189 e ss..

(3) Veja-se Eça de QueIrós, Um Génio Que Era Um Santo, in «In Memoriam de Antero de Quental», Porto, Mathieu Lugan, 1896, pp. 485-486. Cf. ANTERo DE QUental, op. cit., pp. 184-202. 
Mas, se este consenso nos parece indesmentível, o certo é que, como vimos, as formas concretas de fundamentação das suas propostas regeneradoras basearam-se, dominantemente, numa via metodológica anti-teológica e anti-metafísica, isto é, naturalista, voltada para a defesa de um projecto político que se adequasse aos interesses das classes intermediárias sem se ter necessidade de contestar as bases da sociedade capitalista. Ora, a crença na capacidade de se chegar por via científica à descoberta das leis da sociedade exigia a existência de um optimismo cientista, ou melhor, de uma ideologia da ciência só possível de emergir numa sociedade onde os estudos das ciências exactas, e nomeadamente das ciências naturais, estivessem desenvolvidos. É por tudo isto que, para explicar a irrupção do positivismo sociológico em Portugal, julgamos ser necessário juntar aos condicionamentos económico-sociais e ideológicos a importância do incremento dos estudos científicos nas Escolas Médico-Cirúrgicas e nas Politécnicas de Lisboa (1) e Porto, sobretudo no campo das ciências - Física, Química e Anatomia - que mais directamente determinaram a metodologia que A. Comte propôs para análise dos fenómenos sociais. E a prova de que a importância das Escolas Politécnicas na introdução do positivismo em Portugal foi grande está no facto de a primeira divulgação da filosofia comteana ter sido feita no âmbito dos estudos nelas ministrados (2).

(1) A Escola Politécnica de Lisboa foi fundada pelo Decreto de 11 de Janeiro de 1837. Do seu elenco constavam, entre outras, as seguintes cadeiras: Aritmética, Álgebra Transcendental, Mecânica, Astronomia, Física, Química, Mineralogia, Anatomia, Botânica e Economia Política. Veja-se JosÉ Silvestre Ribeiro, Historia dos Estabelecimentos Scientificos em Portugal, vol. 7, Lisboa, Typographia da Academia Real das Sciencias, 1878, pp. 122-142, e vol. 12, pp. 255-295. Sobre os elementos condicionantes do aparecimento do positivismo em Portugal, veja-se JoEL SERrão, Sampaio Bruno e o Positivismo, in «Revista Filosófica», n. ${ }^{\circ} 20$, Agosto, 1957, pp. 229 e ss.

(2) Teixeira Bastos, um dos impulsionadores do movimento positivista entre nós, pensava igualmente que «Em Portugal a filosofia positiva encontrou adeptos com maior facilidade, porque a dissolução teológica fora apressada, pela educação metafísica da Universidade, das Politécnicas e das Escolas de Medicina» (Teixeira Bastos, Teófilo Braga e a sua obra, Porto, Livraria Internacional de Ernesto Chardron, 1892, p. 263). 


\section{OS PRIMEIROS POSITIVISTAS}

É tradicionalmente apresentado TeófILo BRAGA como o primeiro positivista português que aplicou a filosofia comteana aos domínios da realidade social. Para a construção desta ideia feita muito contribuíram os testemunhos autobiográficos dados pelo próprio TeóFILo e seus discípulos mais directos. No entanto, uma investigação mais cuidada, que não se limite às simples fontes literárias, facilmente detecta a perfilhação do ideário de CoMTE muito antes de Teófilo ter começado, em 1872, a utilizá-lo na sistematização da história da literatura $\left({ }^{1}\right)$.

$\mathrm{Na}$ verdade, como assinala Fran PACHECo, primeiramente, o positivismo penetrou entre nós, «....sob o aspecto matemático, na Politécnica do Porto, com a Mecânica Racional de Freyeinet, discípulo de Comte, e na Politécnica de Lisboa, com a Geometria Descritiva, adoptada por Mariano de Carvalho. Depois disto é que (Té́filo) teve conferências com Joaquim Duarte Moreira De Sousa, professor de matemática no Liceu de Castelo Branco, entre 1865 e 1872»(2).

\section{Introdução do positivismo em Portugal} A prioridade de Manuel Emídio Garcia

Confessou Teófilo que só em 1872 aderiu ao sistema comteano. Ora, no campo dos fenómenos sociais - mais concretamente ao nível do Direito - já em 1865-1866, Manuel Emídio Garcia (1838-1904),

(1) Veja-se Té́filo Braga, Historia das Ideias Republicanas em Portugal, Lisboa, Livraria Internacional, 1880, pp. 201-319; Historia do Romantismo em Portugal, Lisboa, Nova Livraria Internacional, 1880, p. 514; Quarenta Annos de Vida Litteraria, Lisboa, Ed. Arthur Brandão, 1902, pp. LIII-LVI. Veja-se também TeIXeIrA Bastos, Teófilo Braga e a sua Obra, Porto, Livraria Internacional, 1892, p. 11. O próprio LitTré deu guarida a esta versão teofilina, no artigo intitulado La Philosophie Positive en Portugal, in «Philosophie Positive, Revue», t. XIII, 1874, pp. 149-150. Contemporaneamente, historiadores como Albert Silbert, Do Portugal do Antigo Regime ao Portugal Oitocentista, Lisboa, Livros Horizonte, 1972, p. 231, continuam ainda a registar esta mesma versão.

(2) Fran Pacheco, Cartas de Teófilo Braga, Lisboa, Tip. da Imprensa do Diário de Notícias, 1924, pp. 26-27. Veja-se também Sampaio Bruno, Os Modernos Publicistas Portuguezes, Porto, Livraria Chardron, 1905, p. 307. 
professor de Coimbra, comentava e aplicava o pensamento de COMTE nas suas aulas de Direito Administrativo (1).

A personalidade e o pensamento deste lente estão infelizmente esquecidos. Mas, como veremos, para além da iniciativa da introdução do positivismo na nossa Universidade, deve-se-lhe igualmente uma acção propagandística muito relevante em ordem à sua tradução e aplicação política em termos republicanos (2). Deste modo, GARCIA não interpretou segundo uma perspectiva académica o significado de comtismo. Mais, pensamos mesmo que aderiu ao positivismo na medida em que, desde logo, anteviu a dimensão política dessa filosofia e a possibilidade que ela teria de sistematizar um projecto reformador que, ao atacar as instituições monárquicas e a ideologia clerical, evitasse igualmente os malefícios revolucionários do republicanismo socialista. Por isso, a leitura garciana do comtismo foi essencialmente sociopolítica.

E não podia ter sido de outro modo. É que o seu republicanismo democrático datava já dos tempos de estudante e jamais abdicou desse ideal. Mesmo quando professor, MANUEL Emídio GARCIA manteve-se numa inalterável coerência doutrinal que só oscilou na gradual passagem de um republicanismo de dimensão socializante - sobretudo devido à influência das obras de ProudHON e VACHEROT para um republicanismo tout court, de inspiração positivista littreana. Quer isto dizer que o seu positivismo veio a inserir-se numa problemática até aí pautada por teorias que apontavam para um modelo de Estado descentralizado e federalista, para uma ordem económica coope-

(1) «....já em 1866, entrámos neste caminho [da filosofia positivista]. Longe de recuar, temos avançado sempre» (MANuEl Emídio Garcia, Estudo Sociológico, Coimbra, Imprensa Académica, 1880, pág. X). E, num outro estudo, escreveu: "Conquanto, no curso de Ciência da Administração e Direito Administrativo, nós, na qualidade de professor, dirigimos desde 1865 , o ensino, e subordinássemos as nossas prelecções à doutrina e ao método positivo, segundo o Curso de Filosofia de А. Сомте, cujo conhecimento adquirimos por indicação e conselho do sábio lente de matemática e nosso prezado amigo dr. José Falcão" (Manuel Emídio Garcia, Dr. Augusto Manuel Alves da Veiga, in "Galeria Republicana», n. ${ }^{\circ}$ 14, Julho, 1882, p. 3, col. 2).

(2) Desenvolvemos o ideário de Garcia no nosso estudo, em vias de publicação: Positivismo e Republicanismo no Pensamento e na Aç̧ão de Manuel Emídio Garcia. Por este facto, dispensamos muitas referências eruditas exigidas pela exposição que, de uma forma resumida, aqui fazemos do seu ideário. 
rativista e para um regime político de cariz demo-republicano (1). Deste modo, se esta inserção não provocou uma ruptura no ideário de Garcia, isso significou que fez uma interpretação heterodoxa do pensamento comteano. Daí que seja principalmente através dos escritos de LitTré e de seus discípulos, e depois de SPENCER, que venha a estruturar a sua teoria político-social (2).

$\mathrm{Na}$ verdade, um dos primeiros textos da fase positivista que dele conhecemos - as lições manuscritas de Direito Administrativo, respeitantes ao ano lectivo de 1871-1872 - ilustra cabalmente o que afirmamos. A par das teses proudhonianas sobre o descentralismo e o federalismo, encontramos referências explícitas à doutrina e à metodologia comteana, quer na caracterização da sociedade do século XIX como científico-industrial, quer na invocação da necessidade de se estudar os fenómenos sociais segundo uma metodologia experimentalista e na equacionação da estrutura da sociedade em termos de estática e de dinâmica. De tudo isto extraía o corolário político de que só a república seria a forma regimental adequada à natureza e às leis de desenvolvimento da sociedade humana. Isto é, nos seus primeiros textos, o pensamento democrático não positivista surgia enquadrado pelos conceitos e pela metodologia de CомTE e de seus discípulos.

Torna-se evidente que esta heterodoxia positivista correspondia optimamente às necessidades do republicanismo renascente. $\mathrm{O}$ positivismo, enquanto doutrina anti-teológica e anti-metafísica, invocava um estatuto científico para as suas conclusões sociopolíticas e dava, assim, a ilusão de uma dimensão de necessidade e de objectividade às suas reivindicações republicanas.

(1) Ainda em 1870, Manuel Emídio Garcia considerava-se adepto das teorias mutualistas. Isto quer dizer que perfilhava o pensamento do seu colega RoDRIGUES DE BRITo ao nível dos fundamentos do Direito e, em última análise, as expectativas proudhonianas nos domínios socio-políticos. Aliás, como mostraremos no nosso estudo citado, MANUEL EmíDIo GaRCIA jamais deixou de considerar-se um proudhoniano. Só que, com o decorrer dos anos, esse proudhonismo perdeu dimensão económico-social e passou a ser tão-só uma teoria político-administrativa.

(2) O papel iniciador e o carácter heterodoxo do positivismo de GaRCIA foi devidamente assinalado por SAmpaio Bruno ao escrever: «Na verdade, o dr. Emídio Garcia foi um positivista não rigorosamente ortodoxo e ele representou em Coimbra o papel simpático de um iniciador» (SAMPaIo BRUNo, op. cit., p. 315). 
Foi esse o esforço fundamental do trabalho teórico de EMíDıo GARCIA, quer na cátedra, quer na intensa aç̧ão jornalística que desenvolveu durante a sua longa carreira. Deste modo, não admira que o seu apostolado tenha influenciado profundamente muitos dos seus discípulos e leitores, ao mesmo tempo que concitava as iras polémicas dos defensores do ultramontanismo e do reaccionarismo tradicionalista.

\section{A primeira polémica do catolicismo contra o positivismo em Portugal}

Se a influência de Garcia em espíritos como Eça de Queirós (1), Zeferino Cândido, Feio Terenas e em gerações republicanas sucessivas ficou inscrita na maturação das inteligências e na consolidação do ideal político que perfilhava, a ira clerical veio a expressar-se contra ele na primeira polémica que opôs um positivista português ao catolicismo tradicional. Esta peça é exemplar, não só porque mostra a vigilância neo-escolástica em relação à introdução das novas correntes racionalistas e cientistas em Portugal, mas também porque revela o modo heterodoxo como, desde logo, o nosso positivismo interpretou, um pouco diferentemente do que se deu no Brasil, as propostas dogmáticas de СомтE sobre a religião da Humanidade (2).

(1) No nosso citado estudo desenvolveremos este aspecto, particularmente no que concerne às relações entre Eça e Manuel Emídio Garcia. Com efeito, se se tem notado a presença de um misto de proudhonismo-positivista no EçA dos inícios da década de setenta, não se tem sublinhado a influência do lente de Direito sobre o jovem romancista. Ora temos provas de que o seu convívio intelectual foi intenso em Coimbra e pensamos que é altamente sintomático o facto de EÇA, mesmo depois de formado, quando pensou lançar a sua primeira revista de ideias, apelar para a participação de Manuel Emídio Garcia. Do mesmo modo, é ainda a ele que, numa outra carta, se confessa adepto da Internacional e justifica os propósitos revolucionários das primeiras Farpas. As cartas encontram-se transcritas na Revista Nova, n. ${ }^{\circ} 14$, I ano, 25-VI-1902, p. 99.

(2) Diga-se que, a par de algumas analogias, o positivismo português assumiu características diferentes do positivismo brasileiro. Na verdade, enquanto entre nós o dogmatismo da Religião da Humanidade não teve qualquer acolhimento, no Brasil, o positivismo ortodoxo, ensinado por Miguel lemos e Teixeira Mendes, ganhou muitos adeptos. Sobre este assunto, veja-se Cruz Costa, Origens, Fastigio e Declínio 
Evidentemente que Manuel Emídio Garcia, ao perfilhar uma filosofia que relegava para o passado o valor da visão teológica do mundo, que colocava o acento tónico numa ética altruísta, mas laica e agnóstica, e ao tirar destes pressupostos todas as ilações progressistas - a prioridade do progresso sobre a ordem, a secularização do ensino e a republicanização e democratização das instituições políticas - e, além disso, tendo a ousadia de defender tais ideais no seio de uma corporação que se caracterizava dominantemente pela sua fidelidade aos valores tradicionais, tinha de defrontar-se, tarde ou cedo, com os corifeus do catolicismo escolasticizado. A campanha começou em 1873 e teve vários níveis - foi desde a polémica de ideais até ao insulto - e envolveu os principais órgãos ultramontanos da época (1).

A primeira crítica séria surgiu de um seu colega de Universidade, Manuel da Motta-Veiga, lente da Faculdade de Teologia. Aproveitando as suas habituais conferências proferidas do púlpito da Sé Nova de Coimbra, o teólogo lançou-se contra as correntes racionalistas, acusando-as de materialistas, ateístas e amorais, e, numa referência directa ao ensino de MANuel Emídio Garcia, lastimou o facto de essas ideias estarem a ser divulgadas na própria Universidade, contribuindo, assim, para a deformação da juventude portuguesa (2). O discurso de MotTA-VEIGA estava em consonância com o movimento neo-escolástico e com a sua ofensiva contra o pensamento oitocentista de inspiração laica,

do Positivismo no Brasil, in "Revista Filosófica», n. ${ }^{\circ}$ 20, VII ano, Agosto, 1957, pp. 134-45.

(1) Vejam-se, entre outros, os artigos: O Positivismo e o sr. dr. Garcia, in «Bem Público», n. ${ }^{\circ} 41$, 19-IV-1873, p. 323; n. ${ }^{\circ} 42$, 26-IV-1873, pp. 331-334; n. ${ }^{\circ} 43$, 3-V-1873, pp. 339-342; "A Nação», n. ${ }^{\circ} 8432$, 4-IV-1873, p. 3; O sr. dr. Garcia na Universidade, in "A Ordem», n. ${ }^{\circ} 106,19-\mathrm{XI}-1879, \mathrm{n} .{ }^{\circ} 108,26-\mathrm{XI}-1879 ; \mathrm{n} .{ }^{\circ} 110$, 3-XII-1879; Sena de Freitas, $O$ Ensino Atheu e o Governo Portuguez, in «O Progresso Catholico", n. ${ }^{\circ}$ 3, 30-XI-1880, p. 25; LuIz Maria Da Silva Ramos, Um Capitulo d'uma Obra Inedita, in "A Sciencia Catholica», vol. $1 .^{\circ}$, n. ${ }^{\circ} 17,1884$, p. 260 ; n. ${ }^{\circ} 19$, pp. 289-294, n. ${ }^{\circ} 21$, pp. 321-325; n. ${ }^{\circ} 23$, pp. 353-359.

(2) Veja-se, M. Motta-Veiga, Conferencias Religiosas recitadas na Se Cathedral de Coimbra em os Domingos de Ramos, Coimbra, Imprensa Nacional, 1874, pp. 1-12. Evidentemente que também a nível interno esta acusação não foi isolada. Pelo contrário, ela inseriu-se na acção polémica da Faculdade de Teologia contra o pensamento não católico e racionalista. Sobre este assunto, veja-se MARIA FerNANDA ReIS Figueira, A Faculdade de Teologia e o "Racionalismo» do séc. $X I X$, Coimbra, 1970. 
ofensiva que tinha em Guthelin, Dupanloup, Doellinger e ReusCLER (1) os seus principais mentores eclesiásticos europeus.

MANUEl Emídio Garcia respondeu ao remoque nas páginas do jornal que então dirigia, Correspondência de Coimbra, nestes termos: «....verificou-se no Domingo (Quaresma de 1873), como tínhamos anunciado, a conferência feita pelo sr. dr. MotTA-Veiga, erudito professor de Teologia e uma das reputações mais sólidas da Universidade.... Celebrou com entusiasmo fervoroso, a moral do cristianismo, a mais pura e social do homem.... Foi, porém, mais do que infeliz, pareceu-nos injusto na apreciação da filosofia do século, que ele denominou filosofia positiva» (2). Para Garcia, essa injustiça derivava do facto de o lente teólogo não ter ainda compreendido o essencial do positivismo, pois revelava um desconhecimento dos textos comteanos fundamentais. Se possuísse esse conhecimento - replicava GARCIA - , veria que o positivismo, longe de ser uma teoria materialista, era espiritualista e, longe de ser doutrina amoral, pugnava por uma ética que, estando assente no princípio do altruísmo, não se afastava do ideal de fraternidade pregado por Jesus Cristo. Por conseguinte, se o positivismo apontava para a instauração de um reino de liberdade, igualdade e fraternidade, ele mais não fazia do que continuar no século XIX, com outros argumentos, o caminho iniciado por Cristo. E isto porque, para GARCIA, «.... liberdade individual, a igualdade jurídica e a fraternidade moral e social têm a sua fonte puríssima na doutrina de Jesus Cristo» (3).

MotTA-Veiga retorquiu no número seguinte, procurando fundamentar pormenorizadamente as acusações proferidas na conferência. Assim, citando textos de COMTE, renovou a definição do positivismo como um sistema materialista, céptico em moral, pois negava a exis-

(1) São estes mesmos autores que vieram a inspirar a crítica de CARLos José Caldeira ao positivismo e aos escritos de Manuel Emídio Garcia e Teófilo Braga. Veja-se Carlos José Caldeira, $O$ Positivismo e a Sociedade, Guimarães, Centro de Propaganda Catholica, 1881.

(2) Manuel Emídio Garcia, Moral e Religião, in "Correspondência de Coimbra», n. ${ }^{\circ}$ 15, 6-IV-1873, p. 2, col. 3. Inspirava-se directamente nos escritos positivistas de ANDRÉ NuYTz, Le Positivisme et l'École Experimentale, in «Philosophie Positive, Revue», t. IV, 1869, pp. 135-153, e no prefácio de É. LITTRÉ à obra de A. LeblaIs, Matérialisme et Spiritualisme, Paris, Germer Baillière, 1865, pp. XVII-XXIV.

(3) Manuel Emídio Garcia, art. cit., p. 2, col. 4. 
tência de Deus, a espiritualidade da alma, a liberdade e a dimensão escatológica do homem (1).

Perante os novos argumentos, Manuel Emídio Garcia não respondeu em termos de problematização filosófica. Ao contrário, apercebendo-se de que MotTA-VEIGA não conhecia de facto as obras de Comte e de que se socorria de um texto do Abade Guthelin, Les Doctrines Positivistes en France, do qual fazia uma tradução directa na sua argumentação, limitou-se a mostrar o plágio que o teólogo português fez dessa obra.

Mas, para além do facto de a polémica não ter atingido grande profundidade doutrinal, o seu significado não deixou de ser importante, dado que a desmistificação feita por GARCIA funcionou como uma retumbante vitória do pensamento positivista sobre a filosofia teológica.

Por outro lado, é indiscutível que, através dela, se pode detectar o modo como Manuel Emídio Garcia e, no fundo, o movimento positivista encaravam o fenómeno religioso. Para eles, o catolicismo tinha sido um momento alto e necessário na evolução do espírito humano e o essencial da sua mensagem seria compatível com o que, para o positivismo republicano e demo-burguês, era fundamental no campo da regeneração social.

Assim, distanciava-se quer do dogmatismo religioso de CoMTE, quer da sua fobia contra o papel evangélico de Jesus Cristo. Como se sabe, A. CомтE depreciou a importância religiosa de Cristo e, dada a dimensão racional e ecuménica do pensamento e acção de S. Paulo, colocava-o como o verdadeiro fundador da Igreja (2). Ao contrário, para Garcia, o Evangelho, desde que interpretado como uma obra histórica, teria consignado os princípios fundamentais da convivência humana que caberia ao século XIX realizar. Para isso, havia que combater a versão teológica dogmatizada pela hierarquia eclesiástica. Deste modo, o positivismo heterodoxo português, logo

(1) Veja-se Motta-Veiga, Moral e Religião - carta, in "Correspondência de Coimbra», n. ${ }^{\circ} 19,4-V-1873$, p. 2, col. 5, e p. 3, cols. 1-3.

(2) «....le grand S. PAUl, seul fondateur réel du catholicisme» (A. ComTE, Système, t. III, p. XXXIX). Sobre a acusação de que Cristo não passava de um milagreiro teológico, veja-se A. ComTE, Système, t. II, pp. 108, 115; t. III, pp. 429-430 Sobre a influência de $\mathrm{S}$. Paulo na religião comteana, veja-se HeNRI DE LUBAC, op. cit., pp. 192-198. 
nos seus inícios, nada teve a ver com a Igreja comteana, não se definindo nem como anti-cristão, nem anti-católico, mas dominantemente como anti-clerical.

\section{A transformação do movimento positivista em corrente de opinião}

Foi durante a década de setenta que o movimento positivista se começou a traduzir numa forte corrente doutrinal. Isso não admira, se levarmos em conta a sua vocação eminentemente política e as suas características essencialmente republicanas e anti-clericais.

$\mathrm{Na}$ verdade, com a agudização da luta de classes e sobretudo das contradições entre fraç̧ões e camadas da burguesia portuguesa ( ${ }^{1}$ ), com o impacto produzido pela Comuna de Paris (1871) (2) e pela revolução republicana espanhola (1873-1874), tornaram-se mais nítidas as diferenças existentes no seio do movimento democrático. Assim, enquanto a corrente socialista se autonomiza e segue de perto, ainda que confusamente, os ditames dos Congressos de Londres e de Haia ( $\left.{ }^{3}\right)$, vindo a constituir-se em Partido, em $1875\left({ }^{4}\right)$, o democratismo republicano tende a delimitar-se das correntes socialistas e a polarizar toda a sua acção na luta contra o regime monárquico e contra o clero ${ }^{(5)}$.

(1) Quanto às greves neste período, veja-se JoEl SERRÃo, Greves, in «Dicionário de História de Portugal», vol. 2, p. 380. Sobre a situação económica, veja-se Rodrigues de Freitas, Crise Monetária e Politica de 1876, Porto, Livraria Moré, 1876, e Armando De Castro, $A$ Revolução Industrial em Portugal no século XIX, pp. 142-185.

(2) Sobre o impacto da Comuna em Portugal, veja-se AnA Maria Alves, Portugal e a Comuna de Paris, Lisboa, Ed. Estampa, 1971.

(3) Quanto à introdução da Internacional e às mudanças qualitativas que operou no carácter mutualista do movimento operário português, veja-se CÉSAR De Oliveira, O Socialismo em Portugal, Porto, Ed. Afrontamento, 1973, pp. 139-181, e Carlos DA FonseCA, A Origem da $1 .^{a}$ Internacional em Lisboa, Lisboa, Ed. Estampa, 1973. O testemunho de um internacionalista ligado a essa penetração encontra-se em: Anzelmo Lorenzo, El Proletariado Militante - Memórias de un Internacional, Barcelona, Ed. Zero, S. A., 1974, pp. 158-163.

(4) Sobre o nascimento do Partido Socialista, veja-se Carlos DA Fonseca, op. cit., pp. 41-58; CÉsAR Nogueira, Notas para a História do Socialismo em Portugal, vol. 1, Lisboa, Ed. Portugália, 1973, pp. 17-33; CÉSAR de Oliveira, op. cit., pp. 132-183.

(5) A fundação do Partido Republicano, em 25 de Março de 1876, foi sobretudo uma resposta à criação do Partido Socialista e, principalmente, à reordenação 
Deste modo ficou fixada a diferença fundamental entre os dois movimentos: o socialista procurou sobrevalorizar as questões sociais ligadas à propriedade privada e à educação das camadas populares, desvalorizando a questão do regime, enquanto o republicanismo centrou a sua doutrinação na prioridade do derrube da monarquia e da laicização das consciências, relegando para as calendas todas as reformas económicas e sociais de dimensão estrutural. Daí o empolamento que deu aos problemas económicos conjunturais e a constante reivindicação de pontos que sensibilizavam as classes médias: a situação financeira, o ensino livre e obrigatório, a separação entre a Igreja e o Estado, a descentralização administrativa, o sufragismo, e o nacionalismo colonialista (1).

No entanto, não se pense que foi fácil a consolidação do republicanismo como um movimento politicamente organizado. Animado sobretudo por intelectuais oriundos das classes médias, sofreu as vicissitudes típicas dos partidos das classes dominantes em sociedade capitalista: a fluidez e ecletismo doutrinal e uma organização assente no regionalismo e no clubismo. Assim, não se estranha que no seio do movimento se digladiassem várias correntes: federalistas, unitários, radicais, oportunistas ( $\left.{ }^{2}\right)$ e que só tardiamente essa unidade se viesse a selar ao redor de um programa e de uma organização mais ou menos unificada (3).

Como veremos, não foi pequeno o contributo do positivismo para a coesão doutrinal do Partido Republicano. No fundo, o nosso repu-

dos partidos monárquicos, os quais, com a fusão do Partido Histórico e do Partido Reformista no Partido Progressista, visaram dar uma melhor resposta à crise económica, social e política, de modo a poderem governar em rotativismo. Cf. Lopes D'Oliveira, História da República Portuguesa, Lisboa, Ed. Inquérito, 1947, p. 33.

(1) Veja-se Joaquim De CARvalho, Formação da Ideologia Republicana, in LuIs DE Montalvor, «História do regimen repúblicano em Portugal», vol. 1, Lisboa, Ed. Século, 1932, pp. 163-256.

(2) Veja-se Johquim Martins de Carvalho, Mais Reflexões Politicas, in «O Conimbricense», n. ${ }^{\circ} 3379,1879$, p. 1, cols. 1-2 e Joaquim de Carvalho, op. cit., p. 250.

(3) Comparem-se os sucessivos programas republicanos elaborados na década de setenta: Programa do Centro Republicano Federal de Lisboa (1873), Programa do Centro Republicano Federal (1878) e Programa do Partido Republicano Unitário (1880). Cf. Joaquim de Carvalho, op. cit., pp. 251-256. Essa unificação deu-se à volta do Programa do Partido Republicano Unificado. 
blicanismo sentiu de perto as sequelas da Comuna em França, onde, depois da repressão burguesa, veio a instalar-se uma república moderada, na qual não foi despicienda a influência do ideário comteano (1) - basta analisar o pensamento de alguns dos seus principais caudilhos: Gambetta e Jules Ferry (2). Deste modo, também entre nós, desde cedo se inicia o acasalamento entre o positivismo e o republicanismo. Em 1874, já LitTRÉ se congratulava pelo avanço da filosofia positivista em Portugal e, em 1880, Teófilo Braga considerava como integrados no seu movimento José falcão, Emídio Garcia, Bernardino Machado, Correia Barata, Zeferino Cândido, Rodrigues de Freitas, Alexandre da Conceição, Alves da Veiga, Ramalho Ortigão, Bento Moreno, Júlio de Matos, Pedro Gastão Mesnier, laborde Barata, Teixeira Bastos, Vicente Pinheiro, Alves de Sá, Bettencourt raposo, horácio Ferrari, Augusto Rocha, João Diogo, Moreira De SousA, aos quais ainda há a juntar Consiglieri Pedroso e VAsconCELOS ABReU (3). Levando em conta a importância destes intelectuais no movimento cultural português da época, temos de concluir que o positivismo dominava em Portugal nos fins da década de setenta $\left({ }^{4}\right)$.

Com efeito, desde os domínios do saber académico - o Direito, a Literatura, a Antropologia, a Psiquiatria -, passando pela análise e a metodologia literária, até à perspectivação política de massas, o positivismo inundou gradualmente todos os domínios da ciência e da cultura em Portugal. Como sabemos, não se tratava de um comtismo ortodoxo e exclusivo, mas antes de uma corrente que apensava ao essencial da doutrina o que de fundamental se ia desenvolvendo nos vários domínios das ciências da natureza e no campo das doutrinas demo-republicanas. Assim, para além de CoMTE, LitTRÉ e a sua escola e Letourneau, os positivistas portugueses aderem ao organicismo

(1) Veja-se Teófilo Braga, Historia das Ideias Republicanas em Portugal, pp. 202 e ss.

(2) «Em França nota-se a sua influência profunda desde 1870; foi essa orientação de aperfeiçoamento relativo que solidificou a República e que a lançou no caminho das reformas sem ter a temer os adversários» (TeiXeIra Bastos, Era Nova, in «Era Nova», Lisboa, Escriptorio da «Era Nova», 1881, p. 1). Veja-se também Silva Graça, Gambbetta, in «Idem», pp. 404-13, e Teixeira Bastos, Comte e o Positivismo, pp. 117-9.

(3) Veja-se Té́filo Braga, Historia das Ideias Republicanas em Portugal, p. 195.

(4) Veja-se Joaquim de Carvalho, Estudos de Cultura Portuguesa do século XIX, Coimbra, Por Ordem da Universidade, 1955, p. 163. 
evolucionista spenceriano e aos contributos da escola antropológica darwinista (Wallace, Darwin, Quatrefages são amiúde citados), bem como à crescente influência dos trabalhos de HUXLEY, BüchNer e Haeckel (1); são receptivos à fisiologia de Claude Bernard, às teses de TAINE sobre literatura e a alguns princípios políticos da escola democrática. Corporaliza-se, deste modo, um movimento que, a par dos trabalhos eruditos, saberá também traduzir-se numa corrente de opinião. Para isso plasmaram as suas ideias em jornais e revistas, o que permitiu uma doutrinação alargada às camadas sociais mais alfabetizadas. Consequentemente, ao contrário de outras correntes, como o krausismo, o positivismo conseguiu ser um movimento intelectual com efeitos pertinentes ao nível da opinião pública e da prática política.

Dos jornais e revistas que neste período contribuíram para a realização deste projecto, há que destacar, para além da Correspondência de Coimbra, onde Manuel Emídio Garcia publicou alguns textos de inspiração positivista entre 1872-74, A Evolução (1876), O Século (1877), $O$ Partido do Povo (1878) e O Positivismo (1878).

\section{Três órgãos da imprensa positivista em Coimbra}

A revista $A$ Evolução foi fundada por iniciativa do poeta AleXandre DA Conceição e o seu primeiro número saiu em Novembro de 1876. Como colaboradores da parte ensaística, contou com Teófilo, Consiglieri Pedroso, Augusto Rocha e Alexandre da Conceição e, na parte literária, colaboraram Cesário Verde, Gonçalves Crespo, Sérgio de Castro e António Macedo Papança (2).

(1) «Livros, jornais e revistas aparecem necessariamente, tendo um mérito mais ou menos real e uma vida mais ou menos próspera mas sempre úteis, desde que se submeteram ao critério das ciências positivas. A filosofia de Augusto Comte e a filosofia de Herbert Spencer, as obras de Darwin e os estudos de Littré, os trabalhos de Huxley e de Haeckel e as vulgarizações de Draper e de Bucckner (sic), etc., etc., encontram de dia para dia maior número de adeptos e de verdadeiros crentes no meio da sociedade portuguesa" (TEIXEIRA BASTOS, A sociedade portuguesa e a filosofia positiva, cit. por L. SAAvedRa MACHADo, Reflexos das correntes filosóficas e pedagógicas contemporâneas em Portugal, in "O Instituto», vol. 112, Coimbra, 1949, p. 41).

(2) A redacção da revista, em face de uma observação de MARTins de CARvaLHO, foi obrigada a justificar a não inclusão de EMíDIo GARCIA no número dos colaboradores e fê-lo invocando o carácter essencialmente literário da publicação. Veja-se $A$ Evolução, n. ${ }^{\circ}$ 1, Novembro, 1876, p. 16, cols. 1-2. 
O seu ideário é definido no primeiro editorial, da autoria de AlEXANDRE DA CONCEIÇÃo. Retratando a evolução intelectual da época, verifica-se que «começam finalmente os espíritos a penetrar-se da ideia de que a evolução é o grande princípio das transformações da sociedade, como o é dos indivíduos, como o é talvez de toda a série orgânica» (1). Sintomaticamente, este texto revela que o dinamismo social já era equacionado em termos evolucionistas, o que não deixa de expressar uma quase certa influência das obras de SPENCER (2). Como veremos, este acasalamento entre COMTE e SPENCER adequava-se optimamente às intenções reformistas dos nossos positivistas republicanos, pois permitia a fundamentação de um republicanismo pacífico, eleitoralista e evolutivo.

Partindo do evolucionismo orgânico, que se traduzia espiritualmente na lei dos três estados e cientificamente na hierarquia das ciências, procuravam fomentar a ideia da necessidade objectiva das suas propostas político-sociais. Daí que todas as concepções do mundo e da vida que radicassem numa atitude teológica ou metafísica aparecessem como resquícios do passado e anticientíficas. Era esse o propósito que presidia aos artigos de Teófilo, Traços Gerais da Filosofia Positiva, e de Consiglieri Pedroso, A suposta necessidade da Revolução das Causas Primárias e Secundárias ( $\left.{ }^{3}\right)$.

O ideologismo cientista visava, como escrevemos, dar uma cobertura objectiva e neutral às propostas sociopolíticas que, à sua luz, apareciam aureoladas de um carisma científico. Por isso, Alexandre

(1) AleXANDRe DA CONCEIÇÃo, Introdução, in "A Evolução», n.o 1, Novembro, 1876 , p. 1 , col. 1 .

(2) Só um estudo monográfico específico poderá trazer ensinamentos sobre a penetração da obra de SPENCER em Portugal. Para já, basta-nos notar que encontrámos referências ao seu pensamento na década de sessenta. No entanto, a sua penetração maciça só se deu nos anos setenta. Para confirmar esta ideia, invocamos a entrada dos seus escritos na Biblioteca da Universidade de Coimbra e a sua presença nos catálogos das livrarias. Assim, Os Primeiros Princípios e a Classificação das Ciências entraram na Universidade em 1872 - veja-se Anuário, 1873, pp. 186-210. Por sua vez, em 1878, a Livraria Magalhães \& Moniz anunciava que tinha à venda as seguintes obras de SPENCER em tradução francesa: Os Primeiros Princípios, Princípios de Psicologia, Principios de Biologia, Ensaio sobre o Progresso, Da Educação Moral, Principios de Sociologia - veja-se $O$ Positivismo, n. ${ }^{0} 1$, Porto, Livraria Universal, 1878, contra-capa.

(3) Veja-se $A$ Evolução, n. ${ }^{\circ}$ 5, Março, 1877, pp. 49-50; e n. ${ }^{\circ}$ 3, Janeiro, 1877, p. 33. 
DA CoNCEIÇÃo congratulava-se com o facto de a política estar a perder «....dia a dia o carácter flutuante, convencional e aventureiro que lhe imprimira o espírito juvenil e impaciente, posto que generoso do jacobinismo francês, para se tornar uma verdadeira ciência, cujas leis, como as de todas as ciências, [são] rigorosamente deduzidas da observação inteligente e despreocupada dos factos» (1). Essa ciência iluminadora de uma correcta prática política só podia ser a Sociologia (2).

$A$ Evolução suspendeu a sua publicação em Dezembro de 1877. Entretanto, um novo órgão de inspiração positivista surgia, $O$ Século, dirigido por Correia Barata e Zeferino Cândido. A sua vocação não era directamente política e literária, pois ambicionava ser um órgão de divulgação científica ( ${ }^{3}$ ). Contudo, os seus efeitos na positivificação dos espíritos e na luta contra o pensamento reaccionário não deixavam de politizar as consciências, já que Correia Barata utilizou as suas páginas para defender as concepções darwinistas e positivistas e anatematizar a campanha ultramontana contra o racionalismo e o cientismo modernos.

Com efeito, para os ultramontanos de $A$ Palavra e de $A$ Nação, as hipóteses darwinistas não passaram de invenções ateístas sem qualquer suporte ao nível dos factos provados. Ao contrário, BARATA sustentava que DARWIN não era ateu, só que a sua prática científica assentava na separação do domínio científico e do domínio religioso. Por isso, pensava que a doutrina de DARwIN podia «....ser aceite, sem o mínimo de escrúpulo de consciência, pelo melhor católico, porque há um abismo profundo entre a discussão da origem última ou causa prima de todas as coisas existentes e qualquer sistema que tenha por fim explicar os fenómenos biológicos, inorgânicos ou físicos» (4). E, depois de assinalar a unanimidade das filosofias contemporâneas no respeitante às teses transformistas, concluía que era necessário fazer uma «....distinção rigorosa, ignorada pela teologia, a saber - que há uma independência completa entre o objecto da fé e o da ciência» (5).

(1) Alexandre dA Conceição, art. cit., p. 1, col. 2.

(2) Veja-se Zeferino CÂNDIDO, Questões Sociaes, in "A Evolução", n. 2 , Dezembro, 1876, p. 6, col. 2.

(3) Vejam-se, por exemplo, os artigos de ZEFERINo CÂNDIDo sobre Astronomia popular.

(4) Correia Barata, art. cit., in «O Século», n. ${ }^{0}$ 1, Dezembro, 1876, p. 7.

(5) Idem, ibidem. 
Apesar das conotações políticas que se podem extrair destas duas publicações, foi só com o aparecimento de $O$ Partido do Povo que se deu, ao nível jornalístico, o acasalamento entre o positivismo e o movimento republicano, pois o jornal, dirigido por MANUEL EMíDIo GaRCIA, tinha como epígrafe o princípio comteano Progresso e Ordem e era o órgão oficioso do Centro Republicano de Coimbra.

Sendo assim, não admira que grande parte dos seus artigos doutrinários - saídos da pena de EmíDIo GARCIA (1) - sejam dedicados à perspectivação do republicanismo em termos comteanos, littrenianos e spencerianos, tendo em vista a unificação ideológica e organizativa do movimento republicano. É que o jornal surgiu num momento em que o partido republicano se alargava, procurando vencer os dissídios pessoais, regionais e doutrinais. EmíDIo Garcia e a sua equipa (2) depositavam grande confiança nas possibilidades aglutinadoras da filosofia positivista, pois, sendo esta uma doutrina possuidora de uma objectividade científica, reuniria as condições necessárias para a uniformização e sistematização do pensamento republicano português. Por isso, com a entoação evangélica que a nova filosofia exigia, escreveu: «É necessário, é urgente que o partido republicano se conheça nos seus elementos; que o partido republicano se defina nos seus princípios; que o partido republicano se constitua e organize de um modo harmónico e uniforme, em todo o país, para poder cooperar com dignidade e coerência de opiniões, com sincera união e inteira energia de esforços e com proveito da justa causa que se propõe sustentar e defender, que é a democracia, nada mais nada menos que a emancipação política, a liberdade económica e o aperfeiçoamento moral do povo português» (3).

Ora, a seus olhos, a República era uma forma política cuja exigência e cujo advento estariam inscrito na evolução social, pois «....o movimento da HUMANIDADE, o trabalho útil e produtivo das gerações tende a ins-

(1) Vejam-se os seguintes artigos, escritos por GARCIA: Politica Interna, Politica Externa, Portugal e a Politica na Balança Cientifica da Europa, As Transformações $e$ as Reformas Sociais, A Reforma Eleitoral e o Partido Republicano, As Próximas Eleições e o Partido Republicano, Porque e Como Aceitamos o Sufrágio Universal, $O$ Partido Republicano.

(2) Além de Garcia, colaboraram no jornal: Feio Terenas, Vasconcelos Abreu, Magalhães lima e Alves da Veiga.

(3) Manuel Emfdio Garcia, $O$ Partido Republicano Portuguez, in «O Partido do Povo", n. ${ }^{\circ}$ 17, Junho, 1878, p. 69, col. 4. 
tituir uma ordem social, na qual as leis naturais da existência politica, administrativa e moral, que regem as condições de formação, conservação e desenvolvimento das sociedades, sejam finalmente reconhecidas e aplicadas, na qual as demonstrações da Ciência, substituindo as invençôes teológicas e as suposições metafísicas, assim como as combinações arbitrárias do ecletismo doutrinal, fornecem uma base sólida, estável e real de apreciação e trabalho para a melhor organização do estado social e constituição do governo" (1). Consequentemente, dada a pretensa força de conviç̧ão que decorreria da cientificidade destas conclusões, até «....as naturezas menos reflexas e meditativas, contanto que não sejam desviadas do seu natural pendor e desvairadas pelos partidos retrógrados, ou por interesses ou apetites cegos, facilmente se convencem e muito espontaneamente reconhecem a necessidade urgente de um novo regimen» (2), regime que tinha de assentar no «....estabelecimento da República, porque só ela nos poderá dar o conhecimento das leis naturais e espontâneas particulares ao homem e à sociedade, aplicadas por poderes de um carácter exclusivamente humano, responsável e não podendo obrar senão no interesse do público e tirando toda a sua força e recebendo a sua legitimidade da sua ciência e do seu trabalho produtor» $(3)$.

Deste modo, o ideologismo cientista, como fundamento do republicanismo, recebia uma explicitação ainda pouco comum nesta época. Tirando os escritos de TeófILo - Traços Gerais da Filosofia Positiva (1877) e a História das Ideias Republicanas em Portugal (1880) -, nenhuns outros textos desceram tão directamente à problemática política equacionada à luz do positivismo como os artigos de MANUEL EmíDIo Garcia inseridos em $O$ Partido do Povo. E isto não surpreende se levarmos em conta outros artigos anteriores, nomeadamente a sua teorização sobre os partidos políticos, pois já em 1876, MANUEL EMíDIo GARCIA, recorrendo à filosofia positiva, tentava «ler» o significados político-social dos movimentos partidários. A sua argumentação era simples: se a evolução espontânea do espírito humano constituía o motor das sociedades, e se cada período histórico fundamental tinha como base uma dada concepção filosófica, também cada movimento

(1) Manuel Emídio Garcia, Eleições, in «O Partido do Povo», n. ${ }^{\circ} 32$, Agosto, p. 129 , col. 1 .

(2) Idem, ibidem.

(3) Idem, ibidem. 
político seria a expressão da atitude espiritual dominante numa dada fase dessa evolução. Deste modo, à filosofia teológica fazia corresponder o partido reaccionário - os miguelistas, em termos portugueses; à filosofia metafísica corresponderiam quer os republicanos revolucionários do tipo jacobino, quer os movimentos socialistas; a corrente ecléctica (VICTOR CouSIN) estaria na base de todos os movimentos políticos de compromisso, nomeadamente do partido constitucionalista que, a seus olhos, mais não era do que uma aberrante conciliação entre a teoria do direito divino e a doutrina da soberania popular; por fim, o republicanismo evolucionista seria a consequência lógica da predominância positivista perante os fenómenos sociais (1).

\section{A revista «O Positivismo» (1878)}

Em 1878, Júlio de Matos escrevia do Porto a Teófilo Braga, anunciando que «....um pequeníssimo núcleo de positivistas concebeu aqui a ideia de criar-se entre nós uma Revista Positiva, destinada a vulgarizar as ideias da escola e a oferecer nas diferentes ciências particulares, artigos elevados e conscienciosos ao grupo limitado dos que lêm e pensam» (2). De facto, este desejo de positivificação do espírito público e das élites inte lectuais encontrou o seu momento mais alto, e, sem dúvida, intelectualmente mais fecundo com a fundação, por Júlio DE Matos e por Teófilo Braga, da revista $O$ Positivismo (1878-1881).

É facto que este órgão, ao contrário de $O$ Partido do Povo, não visava situar-se ao nível da simples propaganda política. De certo modo, os efeitos políticos que os republicanos dela colheram resultaram mais das ilações decorrentes da perfilhação e da propagação do positivismo, do que de uma propaganda partidária explícita, pois procuraram criar uma revista teórica no sentido amplo do termo. Por isso, conseguiram aglutinar os principais representantes portugueses do movimento positivista e, através de artigos que englobavam temas de psiquiatria, literatura, história, educação, ciências naturais, sociologia,

(1) Veja-se Manuel Emído Garcia, Os Partidos Políticos, in "Commercio Portuguez», n. ${ }^{\circ}$ 17, 20-IX-1876, p. 1, cols. 1-3. Este artigo encontra-se reproduzido em $O$ Século, 1. ${ }^{\text {a }}$ série, Coimbra, 1877, pp. 159-163. A partir de 1879, a publicação do jornal passou a fazer-se em Lisboa.

(2) Veja-se António Ferrão, Teófilo Braga e o Positivismo em Portugal, Lisboa, Separata do «Boletim de Segunda Classe da Academia das Ciências», 1930, p. 47. 
religião, filosofia, tentaram que os "espíritos portugueses emancipados da teologia e familiarizados com os processos das ciências naturais»" operassem «a renovação mental e moral necessária às transformaçð̃es políticas e sociais» $\left({ }^{1}\right)$.

Quando entrou no terceiro ano de publicação, os responsáveis da revista pensavam que grande parte das suas intenções tinham sido realizadas. «O Positivismo - escreviam - desempenhou o seu programa e o público compreendeu o seu intuito científico assegurando-lhe a existência.... A importância da filosofia positiva faz-se já sentir nos seus efeitos de disciplina na actividade política» (2).

É de facto indiscutível que, com a sua publicação, o movimento encontrou um órgão teórico que $o$ impôs no horizonte intelectual português. E, se posteriormente jamais os nossos positivistas conseguiram erguer uma revista com o nível intelectual da publicação de JúLIO DE MATOS - a sua publicação terminou em 1884 -, o certo é que a presença do ideário de СомтE e de seus continuadores heterodoxos foi inundando o nosso pensamento filosófico e político, tornando-se no mais poderoso movimento de ideais do Portugal finissecular. Para a concretização desta tendência muito contribuíu esta revista que, em Portugal, procurou realizar a tarefa que em França cabia à Philosophie Positive, de Litrré (3).

\section{POSITIVISMO E REPUBLICANISMO}

A sociedade como uma totalidade orgânica

Como vimos, a elaboração de um projecto sociológico exigia que a sociedade fosse posicionada como uma entidade natural, passivel de ser observada e experimentada e, por conseguinte, capaz de tornar transparentes as leis do seu funcionamento interno. Logicamente,

(1) O Positivismo, n. ${ }^{\circ}$ 4, Abril-Maio, 1880, contra-capa.

(2) O Positivismo, n. ${ }^{\circ}$ 1, III ano, Outubro-Novembro, 1881, contra--capa.

(3) Sendo nosso propósito estudar tão-só os inícios do movimento positivista, não destacamos aqui o relevante papel desempenhado por órgãos como a Era Nova, A Vanguarda, O Século, O Comércio de Portugal, Revista de Estudos Livres e outros, na consolidação do movimento positivista durante a década de oitenta. 
a resposta epistemológica a esta evidência tinha de variar segundo o ponto de vista de classe e a consequente aparelhagem conceptual e metodológica utilizada na leitura da fenomenalidade social. Ora a posição do positivismo de COMTE foi inequívoca, pois, de uma forma explícita, procurou sistematizar uma «ciência» capaz de justificar o domínio económico, político e ideológico do grande capital, e evitar os perigos revolucionários que o ameaçavam. $\mathrm{O}$ modelo biológico correspondia a esta necessidade, já que, em nome da reprodução do status quo, fundamentava uma filosofia da história que procurava invalidar tanto o tradicionalismo reaccionário como o revolucionarismo burguês e socialista.

O biologismo foi, assim, uma ideologia cientista a que a burguesia dominante recorreu para teorizar os seus interesses específicos de classe. No entanto, dizer isto não significa que essa utilização fosse uniforme, dado que, se a grande parte dos ideólogos burgleses oitocentistas se serviram do biologismo para justificar propostas essencialmente reaccionárias - o comtismo ortodoxo insere-se nesta corrente - , houve, contudo, outros sectores que, devido a antagonismos no seio do bloco social dominante, recorreram ao biologismo para justificar interesses de classe que se opunham quer à alta burguesia, quer às correntes revolucionárias (1).

Ora, julgamos que a óptica com que os nossos primeiros positivistas interpretaram o estatuto do real social tem que ver com esta última posição, pois o seu organicismo visou, como veremos, alicerçar doutrinalmente uma política que compatibilizasse a ordem com o progresso, mas no sentido dos interesses das classes intermédias da sociedade (2).

(1) Não é nosso propósito, nos capítulos que se seguem, fazer uma exposição pormenorizada da problemática dos positivistas portugueses oitocentistas. Pelo contrário, limitar-nos-emos a detectar as linhas gerais e essenciais que foram comuns à grande maioria dos positivistas republicanos, não salientando as divergências secundárias entre si. Por outro lado, recorremos de preferência aos textos escritos até aos inícios da década de oitenta. Só citaremos textos posteriores quando se torne necessário reforçar alguma ideia que seja comum a todo o movimento, ou quando se tratar de obras - como o Sistema de Sociologia, de TEófilo - , que foram escritas durante o período que preferencialmente estudamos.

(2) Quer isto dizer que não perfilhamos a tese maximalista, segundo a qual: «En philosophie comme en sociologie, le biologisme a toujours été le point de départ d'idéologies réactionnaires» (Georges LuKács, La Destruction de la Raison, vol. 2, Paris, L'Arche Éditeur, 1959, p. 233). É certo que a partir do modelo biologista se fundamentaram ideologias cientistas de cariz reaccionário (Сомте do Système, 
Assim, seguindo Comte, Spencer, Littré, Vitry, Letourneau, Schaffle, Fouillé, Bordier e outros, parecia-lhes evidente a existência de «....um certo paralelismo entre a vida orgânica e social, e portanto as leis que se aplicam àquele [ao organismo] devem igualmente aplicar-se à sociologia» $\left({ }^{1}\right)$.

Portanto, a sociedade era definida como uma totalidade orgânica possuidora de uma dimensão ôntica autónoma em relação aos indivíduos que a constituíam. Deste modo, o positivismo era essencialmente anti-nominalista, pois o todo social não era identificável ao somatório das partes constituintes. Este facto permitia analisá-lo como uma realidade observável, passível de uma experimentação que, ainda que indirecta, possibilitaria a descoberta de leis universais.

Por outro lado, o facto de a sociedade ser somente um prolongamento da realidade biológica inscrevia-a numa dependência cósmica que implicava a tributação da especificidade e da natureza das suas leis às doutrinas explicativas do mundo natural e biológico (2).

Gobineau, Chamberlain); contudo, e principalmente devido ao impacto do darwinismo, demarcou-se igualmente uma corrente doutrinal que, voltada para os interesses da pequena-burguesia (positivismo heterodoxo), pode ser considerada como conservadora, no sentido amplo e littreniano do termo, isto é, propugnadora de um progresso capitalista assente na ordem, e visceralmente anti-feudal e anti-socialista. Do outro lado, se a teoria social marxista nada tem com o biologismo, é indiscutível que as ideias de DARwin, na medida em que davam uma dimensão histórica à natureza, foram recebidas com entusiasmo por MARx e Engels. Vejam-se as Cartas de Engels a Marx de 12-XII-1859, as de Marx a Engels de 19-12-1860 e a Kugelmann de 27-VII-1870. Sobre as ligações objectivas entre as teorias de DARWIN e o materialismo dialéctico de inspiração engelsiana, veja-se G. V. Platonov, Darwinismo y Filosofia, Buenos Aires, Editorial Lautaro, 1963. Por outro lado, os equívocos respeitantes às relações entre a filosofia materialista e as ciências estão bem patentes nas pretensões do biologismo de LYSENKO que se saldou num obstáculo epistemológico ao desenvolvimento da Biologia e numa leitura positivista do materialismo dialéctico. Veja-se Dominique Lecourt, Lysenko-Histoire réelle d'une «science prolétarienne", Paris, François Maspero, 1976.

(1) MANuel Emídio Garcia, Divisa Interna da Sociologia, in "O Instituto", vol. 30, Julho, 1882, p. 12. Apontam no mesmo sentido biologista Zeferino CÂNDIDo, Questões Sociaes, in "A Evolução», Dezembro, 1876, p. 1, col. 2; TeIXeIra Bastos, Origem da Familia, in «O Positivismo», n. ${ }^{\circ} 3$, I ano, Abril-Maio, 1879, pp. 255-268; Teófilo Braga, Sociologia, in «O Positivismo», n. ${ }^{\circ} 1$, III ano, Outubro-Novembro, 1880, pp. 22-23 e n. ${ }^{\circ}$ 3, III ano, Fevereiro-Março, 1881, pp. 165 e ss.; Horácio Ferrari, Discurso lido na sessão de abertura do Centro Republicano Federal, Coimbra, Typ. Democrática, 1879, pp. 7-10.

(2) Veja-se Émile Callot, La Societé et son Environnement, Paris, Éd. Marcel Rivière, 1952, pp. 118-150. 
Ora, como se sabe, o século XIX assistiu a uma verdadeira revolução no domínio dos estudos dos seres orgânicos. Por conseguinte, a indagação da especificidade de uma teoria sociológica organicista exige que se analise previamente qual o modelo biológico que serviu de paradigma à interpretação do real social. Quer isto dizer que, em termos de ideologia cientista e respectivas implicações sociopolíticas, não foi indiferente recorrer-se ao fixismo de CUVIER, ao evolucionismo de LAMARCK ou ao transformismo de DARwin.

Augusto Comte, por exemplo, manteve-se a uma certa distância das teses lamarckianas, e isso levou a que a sua sociologia constituísse um obstáculo à imposição das concepções transformistas (1). É certo que o autor do Cours aceitou o princípio da modificação morfológica pelo hábito, a lei da transmissão das modificações através da hereditariedade, bem como, inspirando-se em Gall, a lei do inatismo das aptidões. Pode mesmo detectar-se uma analogia que coloca a realidade físico-biológica como fundamento do próprio progresso humano (2). No entanto, a sua fidelidade ao fixismo de Cuvier e à escola biológica de MonTPEllier, levou-o a chamar a atenção para os perigos doutrinais e anti-histórico-continuistas que podiam resultar da aceitação das teorias transformistas.

Sendo assim, o sociologismo comteano ortodoxo constituía uma doutrina que não podia integrar as últimas descobertas ao nível da biologia. A esta luz, compreende-se que, gradualmente, o sector heterodoxo procurasse combinar a sua filosofia da história com os ensinamentos de Lamarck, Geofroy Saint-Hilaire, Darwin, Wallace e de Spencer, de modo a conseguir-se uma naturalização das leis da sociedade mais adequada à fundamentação de uma ordem política não tão conservadora como a comteana e mais sintonizada com o progresso das ciências. $\mathrm{Na}$ verdade, SPENCER (e HAECKEL), ao incluir na sua teoria cosmológica uma concepção monista do Ser, e ao incorporar os princípios básicos do transformismo, eliminou o dualismo comteano entre inorgânico e orgânico e conferiu à motricidade social um fundamento mais próximo da analogia com uma realidade biológica historicizada. Pondo entre parênteses a hipótese do Incognoscível e os

(1) Veja-se A. Comte, Cours, vol. 3, p. 345, e ainda pp. 61, 346, 389.

(2) Idem, vol. IV, p. 345; e Système, t. III, p. 614. Cf. Georges CanguiLHEM, op. cit., p. 68. 
seus corolários religiosos e superando as hesitações de LITTRÉ em relação ao transformismo, os nossos positivistas procuravam justificar a posição e o estatuto da realidade social à luz da cosmogénese spenceriana que, como se sabe, assentava nos seguintes axiomas: persistência da força, indestrutibilidade da matéria, continuidade do movimento e evolução da heterogeneidade para a homogeneidade (1).

Oscilando entre CoMte, SPENCER e HAECKel (2) (ou combinando-os, o que foi mais frequente), os nossos positivistas justificavam, assim, a formação e o estatuto do todo social no conjunto dos seres orgânicos e inorgânicos, à luz de uma perspectiva monista (3). E, se

(1) Veja-se Té́filo Braga, Systema de Sociologia, Porto, Livraria Chardron, 1908, pp. 32-33, 74-75. Na verdade, compulsando os textos dos nossos positivistas, sobretudo os escritos depois dos meados da década de setenta, parece-nos indubitável a presença do esquema cosmogónico e da terminologia - órgãos, funções, aparelhos - da filosofia spenceriana. Mas isto não significa que todos aceitassem o seu ponto de partida - $\mathrm{O}$ Incognoscível - ou até algumas das suas conclusões menos metafísicas. De entre as vozes discordantes, destacou-se a de Júlıo DE MATos: «Herbert Spencer, fortalecido com um saber científico assombroso, tentou a formação de um Sistema de Filosofia, construindo-o sobre essa unidade (cósmica, biológica e social) demonstrada pela ciência moderna; a obra é digna do século, mas está viciada por um resto de hábitos metafísicos. Começa a sua construção pela unificação dos problemas metafísicos no Incognoscivel, e reconhecendo-o como existindo de um modo absoluto, explica assim a essência das Religiões e o intuito das Ciências mostrando que estas duas actividades do espírito são harmónicas e não antinómicas. No estudo do Cognoscível, provando a evolução e a multiplicação dos efeitos, ou a homogenia convertendo-se em heterogenia, vicia a lei do progresso com explicações de finalidade» (Júlıo DE Matos, Disciplina Mental, in "O Positivismo», n. ${ }^{\circ}$ 1, I anno, Outubro-Novembro, 1878, p. 12).

(2) Veja-se Teixeira Bastos, A Creação do Homem, in «Era Nova», p. 31.

(3) Utilizando a conceptologia ontológica de SPENCER, TEÓfILo escrevia: «A separação entre fenómenos físicos e morais é meramente arbitrária; não existe antinomia entre eles; assim como o critério e a compreensão do factor tempo, que distingue os fenómenos biológicos, esclareceu todos os problemas de geologia, eliminando a aç̧ão dos cataclismos, explicando-os pelas causas actuais, também a relação de anterioridade, ampliando mais esse critério evolutivo, tirara aos fenómenos psíquicos e sociológicos ou morais esse carácter maravilhoso a que se agarram ainda as teologias. O ponto de vista dinâmico abrange toda a fenomenalidade do universo, e a homogeneidade incoerente tanto se dá nas nebulosas sob a forma de movimento de repulsão, como nas raças humanas que não atingiram a agregação nacional; a heterogeneidade coerente, que começa no núcleo solar, é a mesma que se manifesta na especialização das funções nos organismos superiores, e a diferenciação étnica das raças que formaram civilizações duradouras. Conhecida a forma geral de todo o movimento, que consiste numa oscilação, e as suas repulsões republicanas e agre- 
nem sempre são explícitos quanto à questão do monismo ôntico, o certo é que nos parecem concordes quanto à aceitação da tese segundo a qual não existiria qualquer hiato entre as esferas do ser, mas somente diferenças específicas, e de que, apesar da sociedade ser a realidade mais complexa, a sua explicação científica seria possível através do uso da metodologia das ciências naturais.

Mas a analogia com as sociedades biológicas mostrava também que as sociedades humanas eram seres possuidores de vida e, por conseguinte, atravessados por um dinamismo que exigia uma perfeita adequação entre o organismo e o meio ambiente (1). Ora se CoMTE já tinha chamado a atenção para a dimensão mesológica dos organismos, o espiritualismo da sua filosofia e o fixismo biologista que perfilhava não cobriam aquilo que LAMARCK, WALLACE e DARWIN (2) ensinaram sobre a dinamicidade dos seres vivos. É ao nível da mesologia, que melhor se nota o acasalamento entre o comtismo e o darwinismo ( ${ }^{3}$ ). Por outras palavras, o evolucionismo social fundamentado filosoficamente através da lei dos três estados era corroborado pelo evolucionismo biológico-social.

Assim, a lei da concorrência vital, «....essa grande lei, que podemos chamar a suprema lei da vida, aplicada à existência das sociedades humanas, não só explica a evolução natural e histórica da humanidade

gativas, nada mais era do que exemplificar com o que se passa na progressão social. O processo é de simples analogia.» (Teófilo Braga, Systema de Sociologia, pp. 33-34).

(1) Veja-se Georges Canguilhem, op. cit., p. 72, e La Connaissance de la vie, 2ème éd., Paris, Libraire Philosophique J. Vrin, 1971, pp. 129-138.

(2) Para uma demarcação qualitativa entre as teses fixistas de Cuvier, o evolucionismo especulativo de LAMARCK e o transformismo de DaRWIN e WALLACE, veja-se Jean Bernhardt, Chimie et Biologie au XIXe Siècle, in François Chatelêt, «Histoire de la Philosophie», vol. 6, Paris, Hachette, 1973, pp. 85-119; C. Limoges, La Selection Naturelle, Paris, P.U.F., 1970 e Georges CANGUilhem, op. cit., pp. 131-8. Para uma noção recuperacionista feita à luz do finalismo aristotélico-tomista, veja-se Étienne Gilson, D'Aristote a Darwin et retour, Paris, Libraire Philosophique J. Vrin, 1971, pp. 68-147.

(3) A presença do darwinismo, para além de ser constante em Manuel Emídio Garcia, pode ser detectada em Correia Barata, Pedro Gaspar Mesnier e, particularmente, em: JÚllo DE MATOS, $A$ Evolução em Biologia in «O Positivismo», n. ${ }^{0}$ 1, I ano, Outubro-Novembro, 1878, pp. 395-396; Teófilo Braga, Systema de Sociologia, pp. 26, 64, 117, 119, 121, 165, e Charles Darwin, in «O Occidente», n. ${ }^{\circ} 123$, V ano, 21-V-1882, p. 118; Horácio Esk Ferrari, A Seleç̧ão Natural em Sociologia, in «O Positivismo», n. ${ }^{\circ}$ 2, I ano, Dezembro-Janeiro, 1879, pp. 102-109. 
em geral, mas cada uma das fracções que a dividem, e a sua tendência instinctiva e irresistível para o progresso e para a transformação sucessiva e melhorada. Famílias, tribos, classes, nações e raças, todas as aglomeraç̃os humanas, desde as mais simples e rudimentares até às mais complexas e desenvolvidas, lutam e trabalham no meio em que vivem, ou ao qual pretendem adaptar-se. Essa notável lei decompõe-se em outras, e exerce a sua poderosa influência e aç̧ão directa por diferentes processos que a observação e experiência têm descoberto e a moderna ciência formulado. Entre esses processos, o primeiro e mais importante - é a concorrência vital. Todos os seres, colocados nos mesmos meios, lutam sem tréguas nem descanso para garantir a sua existência individual e colectiva ou específica. E a essa luta para a existência estão sujeitas as nações, ou melhor ainda, as várias sociedades humanas: famílias, tribos, naçס̃es, raças, classes, todos concorrem e concorrendo, lutam para viver e progredir no seio da natureza e da humanidade. A este esforço e a este combate, que têm por fim assegurar a vida, acrescem outros esforços e outros combates, que têm por fim o triunfo e o predomínio dos indivíduos e das raças melhor constituídas para lutar e melhor adaptadas aos meios, aos tempos e aos lugares onde pretendem viver e transformar-se, isto é, progredir. Chama-se a estas leis ou processos - selecção natural e selecção sexual, e à teoria que os explica - transformismo» (1).

Adiante analisaremos as implicações sociopolíticas que os nossos positivistas extraíram desta concepção. No entanto, desde já se torna

(1) Manuel Emídio Garcia, Politica Externa, in «O Partido do Povo», Fevereiro, 1878 , n. ${ }^{\circ} 1$, p. 2, col. 5. Embora não assinado, não temos dúvidas de que foi escrito por Garcia, director do jornal. Também HorÁcio FerRari exprimia esta crença ideológico-cientista nos seguintes termos: «Uma das verdades biológicas que mais importam ao nosso caso, e que desde já convém consignar, é a seguinte: $o$ aperfeiçoamento evolutivo das espécies faz-se pela sobrevivência dos individuos melhor adaptados às condições do meio em que vivem. Este princípio, reconhecido e suficientemente demonstrado, para ser para já considerado como uma verdade adquirida para a ciência, abrange naturalmente a espécie humana, e é uma das bases da sociologia. Efectivamente, depois dos trabalhos históricos escrupulosamente executados nos últimos trinta anos, depois das noções adquiridas por viajantes e exploradores, que visitaram a maior parte das raças selvagens, é impossível deixar de admitir como um facto, que o aperfeiçoamento das raças humanas $e$ o seu progresso social se efeetua pela sobrevivência dos individuos melhor adaptados às condições do meio» (HorÁcIO EsK FERRARI, art. cit., p. 104). Veja-se ainda Júlıo DE MAtos, Ensaio sobre a Evolução em Biologia, in "O Positivismo», I ano, n. ${ }^{\circ} 2$, Dezembro-Janeiro. 1879, pp. 94-101. 
claro que o seu biologismo sociológico apontava nesta direç̧ão: por um lado, as sociedades humanas, tais como as biológicas, possuiriam uma estrutura interna constante, ou melhor, estática - as células, os tecidos, os órgãos, os aparelhos; mas, dada a sua motricidade interna, esse estatismo seria o suporte de um dinamismo indesmentível. Restava saber qual destas duas características prevalecia sobre a outra e qual a forma da sua assumpção ao nível do humano, já que se fundiam a estática e a dinâmica de COMTE com o organicismo e a terminologia spenceriana e haeckeliana, fundamentando-se, assim, ainda mais naturalisticamente, o evolucionismo intelectualista do comtismo, segundo o esquema do Cours. Por outras palavras, o evolucionismo biologista serviu de fundamento material à noção de progresso, a qual tinha a sua tradução espiritual na lei dos três estados. Se pensamos bem, a combinatória do darwinismo com o comtismo significava que não haveria divergências entre esta lei e os princípios gerais do transformismo. Tratar-se-ia somente de duas maneiras de exprimir a mesma realidade: a inexorável evolução das sociedades humanas no sentido da sua crescente perfeição. Assim, combinando-as, poder-se-ia ver melhor como uma tendência natural e espontânea se expressava em termos de progresso humano (1).

$\mathrm{Na}$ verdade, só o homem, dada a sua constituição psicológica, poderia transformar o evolucionismo cósmico em progresso. E era assim que pensava TEÓFILO ao escrever sob a nítida influência de Herbert SPENCER: «....a lei da transformação da matéria, termo relativo do princípio universal da conservação da energia, influenciando-se na lei da evolução ou evolução subordinada aos tipos de espécie, continua a exercer-se mais complicadamente nos agregados humanos nas formas de progresso, coexistindo com as forças de conservação ou ordem» (2). De facto, esta nota definia a relativa

(1) «Na natureza cósmica, nenhuma energia se perde [princípio spenceriano]; no campo sociológico, essa soma de energia que lhe compete, revelando-se na forma de multiplicação dos efeitos, chama-se progresso" (Teófilo Braga, Mentalidade Primitiva, in "O Positivismo», n. ${ }^{\circ}$, I ano, Abril-Maio, 1879, p. 247); ou ainda, «se nos fenómenos cósmicos o seu encadeamento leva à noção filosófica de transformação, se nos fenómenos biológicos essa transformação se acentua numa forma particular de evolução, nos fenómenos sociológicos essa evolução sem tipos definidos, e portanto de uma natureza ainda mais especial, é o que se chama o progresso" (Teófilo Braga, Systema de Sociologia, p. 21).

(2) Idem, p. 22; ou ainda: «Se alguma palavra pode exprimir com rigor as formas do movimento social, é a que contém a noção genérica da multiplicação 
especificidade da sociedade humana em relação às sociedades animais. Nestas, o evolucionismo seria cego, automático e linear; naquelas, assumiria uma expressão espiritual decorrente da entrada do espírito humano na fase positiva, a qual lhe daria a capacidade científico-industrial de compreender e transformar o presente com vista ao futuro e, simultaneamente, explicar a sua própria evolução passada (1). Assim, as possibilidades de perfeição humana teriam aumentado, já que, com a utilização dos ditames da ciência social, o homem iria finalmente racionalizar o seu destino.

Em face do exposto, compreende-se a preocupação de TeófiLo em assinalar as diferenças entre a evolução biológica e a evolução social (2). Esta não teria a unilinearidade que caracterizava a evolução biológica. Ao contrário, a complexidade das sociedades humanas em relação aos outros fenómenos tornava-a mais modificável e, dada a capacidade de participação individual ou colectiva, a sua evolução não poderia ser puramente rectilínea. Este facto era reforçado pela existência do fortuito $\left({ }^{3}\right)$, fenómeno que, juntando-se aos esta-

dos efeitos, a que exprime uma marcha sem estádios definidos; a progressão é realmente o modo da actividade social, como a evolução o é para a actividade biológica” (Idem, p. 54).

(1) Sobre este assunto, TEófilo escreveu: «o movimento do organismo social não é semelhante ao movimento biológico, porque este segue um curso previsto, em fases, períodos ou evoluções sucessivas de tal forma dependentes entre si que, iniciado um impulso, todas as outras formas se desdobram com uma fatalidade tão ligada à sua própria condição de existência, que ClaUde BeRNARD chegou a exprimir pela lúcida palavra determinismo, que encerra em si uma profunda concepção filosófica. O movimento social depende na sua totalidade de factores biológicos, é verdade, mas a multiplicação dos efeitos, que o caracteriza, a parte do acidental e do fortuito na sua impulsão são tão constantes que, em rigor, não só se não podem prever as formas da sua expansão na história, como também está sujeito às modificações da vontade individual» (Teófilo BraGa, op. cit., p. 53).

(2) A dimensão espiritual do progresso social - e, portanto, a do evolucionismo teofiliano -, é particularmente posta em relevo pelo filósofo, que via a tradução da capacidade científico-industrial decorrente do progresso humano na Estética, na Ciência, na Filosofia e, a nível colectivo, na Moral, na Indústria e na Política. Cf. Teófilo Braga, op. cit., p. 513.

(3) Teófilo Braga sintetiza esta característica diferencial dos fenómenos sociais em relação aos fenómenos naturais nos seguintes termos: "Assim como nos agregados químicos mais complicados é maior a sua instabilidade, também nos fenómenos sociais, dependentes de todos os condicionalismos e determinismos anteriores, o seu principal carácter é a sua complicação de tal forma crescente, que o facto sociológico se pode caracterizar pela multiplicação imprevista dos efeitos. Pertence a Spencer esta 
dos de anormalidade e patologia, daria à realidade social um estatuto que atenuava o determinismo unilinear dos fenómenos biológicos $\left({ }^{1}\right)$. Consequentemente, se existiam relações analógicas entre

precisa característica. Por ela se explica a marcha histórica nos fenómenos sociais, onde vemos admitir-se o acaso para explicar dadas transformações sem relação anterior conhecida, o acidental e o ocasional, tudo isto traduzido em frases mais ou menos pomposas de desígnios da providência, acção dos grandes homens, descobertas fortuitas e catástrofes imprevistas.... Se os fenómenos cósmicos e biológicos são por assim dizer tão invariáveis, que podem ser reproduzidos pela experimentação ou compreendidos pela comparação, os fenómenos sociológicos são por sua natureza complicada tão modificados pelas circunstâncias fortuitas, que só pelo seu longo encadeamento em série e pelo método da filiação histórica é que podemos achar-lhe um sentido" (Teófilo BragA, op. cit., pp. 20-21).

(1) Para os positivistas, a posição do homem no cosmos não merecia dúvidas. Prolongamento de uma natureza historizada, a sociedade humana seria atravessada pelas determinantes objectivas decorrentes da evolução cósmica. Assim, este naturalismo invalidava as doutrinas fatalistas e providencialistas (as quais implicam uma causalidade transcendente e imprevisível, cuja compreensão só seria possível através de uma ascensão místico-religiosa) e as teses subjectivistas e metafísicas (as quais colocavam o homem individual no centro do mundo e conferiam à sua vontade e acção uma capacidade criadora ilimitada). É a esta luz que temos de entender as preocupações teóricas de JÚLIO DE MATOS no concernente a esta questão: «...a falsa imagem de Fatalidade com que os metafísicos querem viciar a concepção dinâmica do universo recebe a mais clara subordinação racional na noção positiva do Determinismo, ante a qual se eliminam como fantásticas as entidades tradicionais de Causalidade, Finalidade, Fatalidade e Acaso» (Júlıo DE MAtos, Disciplina Mental, in "O Positivismo", n. ${ }^{\circ} 1$, I ano, Outubro-Novembro, 1878, p. 15, e ainda $O$ Determinismo em Psychologia, in "Idem», pp. 21-30; veja-se também TeófILo Braga, Systema de Sociologia, pp. 55, 137 e 115). Mas, se as relações antecedente-consequente e a possibilidade da sua explicação racional invalidavam as teses fatalistas e providencialistas, o seu necessitarismo «matava» igualmente as doutrinas do subjectivismo kantiano. Assim, no positivismo, não haveria lugar para o livre arbitrio, que não seria mais do que uma invenção metafísica sem qualquer base científica. Por isso, Júlio de Matos, recorrendo às teorias fisiológicas de BaIN e de ClaUde BERNARD, podia concluir: $" 10^{\circ}-$ Que o livre arbítrio e a espontaneidade dos actos voluntários são uma quimera, porque a Fisiologia demonstrou a subordinação destes fenómenos a leis; $2 .^{\circ}$ - Que os movimentos da vontade não são fatais, mas simplesmente condicionados, porque nós podemos intervir neles e modificá-los numa direcção pré-determinada. (Júlıo DE MATOS, art. cit., p. 31; veja-se também CoNSIglieri Pedroso, O Furtuito na História, in «Positivismo», n. ${ }^{\circ}$ cit., p. 17; Teófilo Braga, Systema de Sociologia, p. 29). Sobre as relações entre Fatalismo, Determinismo e Liberdade, desenvolvidas de um ponto de vista histórico-sistemático, veja-se Georges Gurvitch, Déterminismes Sociaux et Liberté Humaine, Paris, P.U.F., 1955, pp. 19-41. 
a realidade biológica e a realidade social, existiam igualmente diferenças, pois na sociedade humana assistia-se a uma gradual comparticipação individual e colectiva na transformação e aperfeiçoamento das relaç̃es morais, económicas e políticas entre os seus membros. E, como vimos, o positivismo candidatava-se a ser a ciência que fornecia os instrumentos científico-industriais conducentes à adequação da organização racional da sociedade com as leis espontâneas do seu evoluir. Em resumo, o positivismo mostrava que, embora sujeito a leis naturais, o real social era essencialmente um ser temporal (1).

Quer isto significar que, embora imbuídos de uma concep̧̧ão naturalista, os nossos positivistas incorporaram a dimensão histórica que o impacto das revoluções totais burguesas e a teorização filosófica tornaram evidente. Só que, enquanto na sistemática metafísica o evolucionismo aparecia mediado por uma problematização finalística (as mónadas em Leibniz, a Ideia em Hegel), os positivistas, invocando o estatuto de cientificidade modelado pelas ciências naturais, esforçaram-se por demonstrar a positividade da sua doutrina. Para isso tiveram de combater qualquer interpretação que tentasse colocar o seu evolucionismo (que uma análise fria e objectiva consegue revelar teleológico) na linha das filosofias da causalidade.

Compreende-se. A concepção causalista do ser tinha feito época no longo reinado aristotélico-tomista. O mecanicismo, contudo,

(1) Com efeito, os nossos positivistas tiver am consciência da mudança de óptica que implicava uma teoria não metafísica do Tempo: «Nas sociedades humanas - escrevia Té́filo - o Tempo é a condição fatal do desenvolvimento, e a sua acção só pode ser compreendida por uma continuação do determinismo biológico" (Té́filo Braga, Systema de Sociologia, p. 63). Quer isto dizer que, como acentuava JÚLIO DE MATOS, a concepção de Tempo recebia «uma natureza filosófica [leia-se: científica] na noção de evolução» (JúLIo DE MATos, Disciplina mental, in "O Positivismo», n. ${ }^{\circ} 1$, I ano, Outubro-Novembro, 1878, p. 15). Tal temporalidade não podia ser, contudo, nem linear nem circular. A existência de perturbações sociais, que tinham «....o poder negativo de retardar a evolução humana; às vezes também, num número de casos, têm-na acelerado» (Consiglieri Pedroso, art. cit., p. 17), levava a que o progresso da sociedade, dependendo do tempo e do aperfeiçoamento sucessivo, fosse «.....apresentado por uma curva referida a estes dois elementos, como eixos coordenados. O progresso principia no infinito passado e, portanto, a curva que o representa deve ser tal que não corte o eixo dos tempos ou das abcissas se não no infinito» (Pedro Gaspar Mesnier, op. cit., p. 91). Era a visão iluminista do progresso assintóptico a ser revivida pelo positivismo heterodoxo. 
com a extensibilidade da substância, matou-a. Mas as modernas reacções anti-cartesianas e anti-espinosianas, sobretudo as de LEIBNIZ e a dos pensadores idealistas dialécticos (FICHTE, Schelling, Hegel), voltaram a repor, embora com fundamentos diferentes, a visão teleológica do Ser. Tais teses, quer por influência directa, quer através das reelaborações de Proudhon, Janet, Vacherot, Caro, Flint, Ribot, Schopenhauer, E. HartmanN, encontraram eco, ent:-e nós, em pensadores como Antero, Cunha Seixas, Ffrreira Deusdado, Bruno. Daí a intensidade polémica com que os nossos positivistas contestaram toda e qualquer concepção ontológica assente em princípios teleológicos (e isto apesar de o próprio positivismo se basear igualmente num evolucionismo finalista) (1).

A argumentação positivista era coerente com o seu conceito de ciência. Só a explicação do como dos fenómenos seria humanamente possivel e qualquer argumentação sobre o porquê do seu acontecer acabaria por cair, em filosofia, ou no teologismo ou no metafisicismo e, em política, ou no reaccionarismo monárquico ou no ecletismo liberal ou revolucionarismo inconsequente. Sendo assim, Consiglieri Pedroso, expressando uma crença que era comum a todo o movimento, criticava os adeptos das causas formais e finais com estas palavras: «A todos aqueles que nos falarem, pois, de causas primárias, causas finais, essência, substância, primeiro motor, etc., etc., responderemos como o autor do Sistema do Mundo respondeu a Bonaparte, ao ser interrogado acerca do lugar que na sua obra deixava a Deus: 'São hipóteses desnecessárias e, portanto, dispensáveis para os progressos das ciências'» (2). Haveria, assim, uma ordem puramente natural que não esconderia no seu recôndito qualquer entidade que transcendesse as simples relações entre os fenómenos. Conhecê-las era a tarefa dos cientistas da natureza e de sociedade. Abandonando a indagação do porquê das coisas, bastaria a explicação de como se relacionavam para se ter a chave conducente à coincidência plena entre a reorganização humana da sociedade e a ordem natural resultante das relações objectivas dos fenómenos do universo.

(1) Veja-se Consiglieri Pedroso, As Causas Primarias e Finaes, in «O Positivismo», n. ${ }^{\circ}$ 1, II anno, Outubro-Novembro, 1879, pp. 10-16. Veja-se também Júlio DE Matos, $A$ Religião do Futuro, n.o 1, I anno, Outubro-Novembro, 1878, pp. 64-73, e $O$ Jesuitismo nos Seculares, in «Era Nova», 1881, pp. 293-296.

(2) Consiglieri Pedroso, art. cit., p. 16. 
Apesar de tudo, a consciência da dimensão histórica das sociedades humanas permitiu que os nossos positivistas republicanos fugissem do determinismo absoluto, o qual, na prática, levava ao atentismo político, e acreditassem que, se a República era naturalmente inevitável, a prática individual e colectiva seria necessária, quer para acelarar o processo histórico, quer para evitar a degenerescência da sociedade. A História aparecia, assim, como o produto de um processo objectivo e natural, cuja explicação última não se encontrava nem na vontade omnisciente de uma causa transcendente, nem no seu inverso, a acção exclusiva e demiúrgica dos indivíduos. Era, portanto, um mundo submetido a um amplo determinismo, mas perfeitamente acessível à observação e à razão humanas. Os indivíduos, longe de serem o seu motor, eram tão só o suporte dessa causalidade, e a sua acção transformadora estaria na razão directa da sua capacidade em compreender e dar vida às necessidades decorrentes do transcurso espontâneo da Humanidade a caminho da sua máxima perfeição na terra (1). Por conseguinte, compreende-se que atacassem as concepções providencialistas (BOSSUET), como o teleologismo imanentista da Ideia (HeGEL) e todas as teorias que exacerbassem as explicações sobre individualistas da História (Thters e Mignet), as quais, a seu ver, mais não eram do que a inversão da explicação teológica (2).

(1) «A complexidade e variabilidade incalculável dos fenómenos que se passam no meio social exigem a necessidade constante de intervenção de vontades coordenadoras, mais ou menos conscientes, e por isso mesmo impulsoras ou retrógadas segundo a sua capacidade» (Teófilo Braga, Systema de Sociologia, p. 146). Quer isto dizer que os nossos positivistas aceitaram a especificidade que Augusto СомтE tinha apontado para as relações entre o organismo e o meio. De facto, embora o autor do Cours tenha procurado erguer uma teoria mesológica dualista, o facto é que se pode detectar o esboço de uma teoria dialectica nas suas concepções entre o organismo e o meio. Sobre este assunto, veja-se (Georges Canguilhem, op. cit., p. 133).

(2) Manuel Emídio Garcia, à luz do positivismo, defendia que: $1 .^{\circ}$ Os grandes homens, os génios, eram o produto de uma evolução anterior e a sua acção e influência seriam nulas ou insignificantes se se manifestassem em épocas e meios diferentes; $2 .^{\circ}$ por outro lado, não eram os grandes homens que geravam os factos e as circunstâncias do seu tempo, mas os factos e as circunstâncias que geravam os grandes homens. A luz deste objectivismo, mesmo as descobertas e invenções, apesar de comumente saírem do cérebro de homens isolados, apareciam como produtos lentamente elaborados e consequências de descobertas sucessivamente feitas e acumuladas durante séculos. Sendo assim, o nomote- 
A lei dos três estados, sendo uma constatação pretensamente científica, abria, assim, o caminho a uma utilização política que, invocando o carisma da ciência, podia combater ideologicamente os adversários do seu corolário sociopolítico e alimentar, ao mesmo tempo, o optimismo interventor daqueles que nela acreditavam. No entanto, esse poder de intervenção não era ilimitado, pois a estrutura histórica tinha de adequar-se ao esiatuto natural das leis sociais (1). Deste modo, a acção humana não devia transgredir o que a «ciência» ditava como sendo a essência dos fenómenos sociais, isto é, a ordem natural da sociedade. E se, como veremos, a estrutura estática das sociedades mais não era do que uma projecção eternizante da ordem capitalista, o teleologismo positivista aparecia, portanto, como uma ideologia cientista que apontava para a eliminação da visão dialéctica do todo social e para a diluição das classes sociais na nomenclatura biologista, subordinando os indivíduos e as classes antagónicas à totalidade capitalista (2).

\section{A lei dos três estados e a sua aplicação crítico-política}

Por conseguinte, a teoria da história do positivismo vinha ao encontro das necessidades polémicas do republicanismo português. A lei dos

tismo dos fenómenos sociais fazia com que a acção dos indivíduos, na esfera política, para ser relevante, tivesse de basear-se no conhecimento do «....passado, compreender bem o presente, prevenir e prever a direcção fenomenal do futuro, impedir e dirigir os povos na sua conquista e realização». Logicamente, os verdadeiros condutores dos povos seriam os indivíduos capazes de prever para prover, isto é, os possuidores de «....um juízo muito esclarecido pela observação e experiência e um raciocínio muito seguro para descobrir, através da infinita complexidade dos fenómenos sociais, a direcção e o sentido da evolução de uma época, e prever futuros acontecimentos e novas transformações" (MANuel Emídio Garcia, Marquês de Pombal-Obra Commemorativa do Centenário da sua Morte, Lisboa, Imprensa Nacional, 1885, pp. 128-129). Por sua vez, Teófilo Braga sistematizava esta mesma ideia no seu livro Systema de Sociologia, pp. 145-158.

(1) «A concepção de determinismo [corrigida por Cuvier, LAMARCK, GefFroY Saint-Hilaire, Comte e Claude Bernard] não podia ficar confinada no campo das ciências biológicas, sob pena de viciar-se nas questões da psicologia; todos os actos da fenomenalidade do universo são condicionados...." (Té́fILo BRAGA, op. cit., p. 29).

(2) Cf. Georges Gurvitch, op. cit., p. 249. 
três estados permitia demonstrar o carácter anti-histórico e anti-científico tanto das propostas monárquico-clericais, como das intençðes revolucionárias dos individualistas e dos socialistas-comunistas (1). Por exemplo, a seus olhos, a monarquia absolutista, na medida em que somente se podia justificar em nome do direito divino, não passava de uma aberração e de um prolongamento, na modernidade, de uma concepção historicamente ultrapassada. Tal anátema era igualmente aplicado à monarquia constitucional, a qual, apesar da pretensa legitimação popular, tentava conciliar o direito dos homens com o direito de Deus. Era, portanto, produto de um eclectismo doutrinal, incapaz de criar um sistema político-social definitivo.

Deste modo, um dos corifeus do movimento positivista português podia afirmar em 1878: "Os homens verdadeiramente patriotas e sinceramente liberais que promoveram e dirigiram a manifestação revolucionária de 24 de Agosto de 1820 eram doutrinários e eclécticos tanto em filosofia como em política.... Consumiram dois anos para dotar o país com uma constituição monárquica-representativa, invocando a Santíssima e Indivisível Trindade, e declarando os portugueses súbditos de um rei investido nas altas prerrogativas do supremo poder por graça de Deus e direito hereditário. Deixaram subsistir na lei fundamental do Estado, medrar à sombra das garantias da liberdade muitos elementos do sistema absolutista, sobressaindo o elemento teológico em quase todas as manifestações políticas» (2).

Por sua vez, em 1879, Latino Coelho, numa carta eleitoral, resumia o pensamento republicano em relação à monarquia constitucional, escrevendo: «a história confirma a posteriori o que a priori se poderá inferir examinando os princípios antinómicos em que assenta a monarquia representativa. De um lado, vemos nela o

(1) «Um espírito disciplinado pela filosofia positiva evita a agitação própria do metafísico revolucionário e ataca, pela doutrina da soberania nacional delegada em uma magistratura temporária e competente, o poder fictício que os conservadores querem converter em apanágio de uma casta ou família dinástica. Nestas condições, a República é a forma política que melhor realiza este princípio científico, que está na aspiração dos povos» (Teófilo Braga, Historia das Ideias Republicanas em Portugal, pp. 324-325).

(2) Manuel Emídio Garcia, Os Partidos Liberais em Portugal, in «O Partido do Povo», n. ${ }^{\circ}$ 22, Julho, p. 89, col. 1. 
direito divino.... Do outro, as estéreis afirmações da soberania popular» (1).

Mas se, por um lado, a historicidade do espírito teológico permitia desmistificar o monarquismo, o criticismo e a transitoriedade das manifestações político-sociais do espírito metafísico, por outro, davam aos republicanos positivistas instrumentos doutrinais para combater quer as concepções do individualismo revolucionário setecentista, quer as propostas socialistas e comunistas que, como fruto do desenvolvimento industrial, iam sendo colocadas como alternativas para a solução da crise da sociedade capitalista (2). Para o positivismo, a necessidade de se adoptar uma atitude criticista (metafísica) em face dos fenómenos sociais esıava ultrapassada. No fundo, tal necessidade decorreu da evolução da história e funcionou somente como antítese do espírito teológico. Foi, portanto, um momento exigido pela teleologia do espírito no seu caminho evolucionista para o reino da positividade definitiva. Ora, tanto o individualismo extremo como os vários socialismos apareciam a seus olhos como contrapostos à sociedade feudal e meros produtos do criticismo espiritual das filosofias do século XVIII e da dos seus continuadores do século XIX. Ao acentuarem unilateralmente o valor do progresso, se estavam a cumprir uma necessidade histórica perante a estagnação feudal, esqueciam-se de compatibilizá-lo com a necessidade da ordem. Deste modo, tornavam-se apóstolos de um revolucionarismo perma-

(1) Cit. por Teófilo Braga, Historia das Ideias Republicanas em Portugal, p. 244. Por sua vez, TEófilo escrevia: «O sistema monárquico parlamentar, nascido da conciliação absurda entre as doutrinas teológicas do direito divino com as fantasmagorias metafísicas do revolucionarismo, não proveio de convicções, mas de interesses» (Teófilo Braga, Systema de Sociologia, p. 300). Veja-se também Teixeira Bastos, Considerações Gerais sobre Sociologia, in "O Positivismo», n. ${ }^{\circ} 6$, IV ano, Novembro-Dezembro, 1882, pp. 463-464.

(2) Daí que Té́filo, ao referir-se às ideias dos socialistas portugueses e particularmente a ANTERO, escrevesse em 1880: «Os elementos metafísicos que se revelaram nas Conferências democráticas do Casino persistiram nessa orientação improgressiva e foram-se inutilizar no quietismo sentimental das aspirações socialistas; nem espalharam lição, porque não aplicaram à questão social da organização do proletariado o critério histórico e filosófico, nem fundaram exemplo, porque pretenderam resolver pelo egoísmo da abstenção política da classe industrial o problema económico, tão solidário como o primeiro [problema político]. A filosofia positiva teve a oportunidade de uma forte disciplina no meio da agitação societária [Internacionalismo] e dos conflitos do clubismo mantido pelo resto dos republicanos sentimentais de 1848» (Teófilo Braga, Historia das Ideias Republicanas em Portugal, p. 199). 
nente. Ora, para os positivistas, o espírito positivo seria orgânico e sistemático e, por isso, a civilização construída sob a sua égide teria de anular a necessidade de proceder a profundas transformaçð̃es económico-sociais.

$\mathrm{Na}$ verdade, a demonstração do valor relativo, transitório e pouco construtivo dos sistemas político-sociais elaborados pelo espírito metafísico possibilitava a contestação das propostas socialistas que, a partir dos inícios da década de setenta, começaram a ser defendidas em Portugal, quer ao nível individual, quer de uma forma organizada. Por isso, os positivistas acusavam os socialistas de não possuírem uma disciplina intelectual e moral capaz de regenerar a sociedade (1). Ao mesmo tempo, a sua sobrevalorização da questão económica demonstrava a inexistência de uma sólida teoria científica no norteamento das suas opções políticas (2).

Mas o individualismo burguês de cariz extremista também não escapava ao crivo das análises positivistas. $\mathrm{O}$ individualismo tout court e os socialismos seriam irmãos gémeos, nascidos das preocupaçðes do espírito revolucionário. No entanto, com a entrada no período positivo, ter-se-ia encerrado a fase criticista e, assim, até os projectos sociopolíticos que não punham em causa a sociedade capitalista, desde que fundamentados em nome de um individualismo extremo, apareciam como sendo extemporâneos. Deste modo, e ao contrário do que se afirma, o positivismo republicano procurou ser uma alternativa moderada e conservadora em relação ao republicanismo jacobinista da Revolução, representada em Portugal pela faç̧ão «lunática» chefiada por Oliveira Marreca e Sousa Brandẽo. Assim se explica que, logo em 1876, Alexandre da Conceição se congratule com o facto de, devido à acção do positivismo, a política estar a perder «....de dia para dia o carácter flutuante, convencional e aventureiro que lhe imprimia o espírito juvenil e impaciente, posto que generoso, de jacobinismo francês»; e que Manuel Emídio Garcia denuncie a existência de duas tendências no seio do republicanismo: «....uma, prossegue uma função negativa e a operação demolidora que

(1) Veja-se Júlio de Matos, A Reorganização da Politica pela Sciência, in «Era Nova», p. 74.

(2) Veja-se adiante a discussão da polémica sobre a prioridade da questão económica ou da questão política entre republicanismo e socialismo. Cf. A. ComTE, Cours, vol. 4, pp. 90-91; Système, t. II, p. 256. 
lhes transmitiu o século XVIII, e promoveu sem descanso, e por meios violentos, uma declarada guerra de extermínio à monarquia e às instituições monárquicas. São os republicanos revolucionários. Os outros, preocupados com a estabilidade da ordem ao mesmo tempo que estimulados pelas necessidades do progresso, pretendem renovar e construir pacificamente a sociedade na sua vida política, moral e económica segundo as leis naturais e espontâneas que regem o organismo social.... São os republicanos revolucionários ou evolucionistas» (1). Explica-se ainda que TeófIlo BragA se esforce pela unificação doutrinal do movimento de modo a acabar com o clubismo dos Centros Republicanos de inspiração jacobina; e, por último, compreende-se também que, em 1881, a revista $O$ Positivismo verifique com entusiasmo o facto de «o radicalismo [ceder] o passo à crítica da evolução histórica» (2).

\section{República Evolucionista e Revolução}

$\mathrm{Na}$ verdade, o positivismo procurava demonstrar que a República era uma necessidade imposta pelas leis sociais. Por outro lado, invocando a correlação existente entre a ordem e o progresso, visava anular quer as pretensões revolucionárias, quer as tentativas regressivas de inspiração monárquica, apontando para um evolucionismo social. Daí que, em 1878, MANUEl Emídio Garcia anunciasse com uma crença cientista inquebrantável: «a monarquia está irremediavelmente decrépita e perdida, a República está iminente em toda a Europa e é inevitável em Portugal do mesmo modo que em todas as nações de origem latina. O nosso meio social, que manifestamente repele a monarquia, está suficientemente preparado para a República que todos os dias e cada vez mais se lhe vai adaptando. E tanto que, o Partido Republicano é, essencialmente, e por força das circunstâncias, o partido da ordem, um partido de propaganda pacífica, de educação democrática. Precisa apenas de actuar no meio social para que o povo possa bem compreender a República, que, queiram ou não queiram os interesseiros e ambiciosos amigos da monarquia, que se dizem realistas por força das circunstân-

(1) Veja-se Alexandre DA Conceição, Introdução, in "A Evolução", n.o 1, Novembro, 1876, p. 1, col. 2; Manuel Emídio Garcia, $O$ Partido Republicano, in "O Partido do Povo», n. ${ }^{\circ}$ 58, I ano, Março, pp. 1, cols. 2-3.

(2) Teófilo Braga, Historia das Ideias Republicanas em Portugal, p. 220; «O Positivismo», n.o 1, III ano, Outubro-Novembro, 1881, contra-capa. 
cias e conveniências partidárias de oportunidade, vem na vanguarda da evolução, como consequência inevitável e ineludível das leis históricas dos povos latinos» (1).

Mas se o organicismo apontava para a necessidade de uma República evolucionista, a verdade é que era ainda à sua luz que os republicanos justificavam o pacifismo eleitoralista e o anti-revolucionarismo então perfilhado pelo movimento - só nos fins da década de oitenta alguns sectores começavam a defender a via conspirativa (2).

A seu ver, as revoluções, apesar de realidades indesmentíveis, não passavam de fenómenos tendentes a repôr o funcionamento normal do organismo social de modo a adequá-lo ao seu percurso teleologicamente determinado pelo evoluir histórico. Mas, se assim tinha sido no passado, a entrada da Humanidade na fase positiva e, mais concretamente, a cientificação dos fenómenos sociais permitiriam a condução de uma prática política que, assente no conhecimento exacto da evolução humana, invalidaria definitivamente a necessidade do recurso às revoluções. A hora dos radicalismos teria passado e a ciência, alicerçando a coexistência da ordem e do progresso, demonstrava a necessidade do evolucionismo em política (3).

Deste modo, Júlio DE MATOS, combatendo o blanquismo, podia justificar o evolucionismo nestes termos: «....não negamos de um modo absoluto a legitimidade da revolução. Assim como no organismo há crises profundas, naturais umas vezes, provocadas outras, que servem para expulsar uma doença, assim nas sociedades há em casos anormais as revoluções que afastam um mal, restabelecendo as bases de equilíbrio que se rompera por condições fortuitas. Mas que diríamos do médico que, abusando do poder da ciência, submetesse de um modo sistemático

(1) Veja-se Manuel Emídio Garcia, $O$ Partido Republicano, in «O Partido do Povo", n. ${ }^{\circ}$ 53, Outubro, 1878, p. 213, cols. 1-2; veja-se também Porque e Como Aceitamos o Sufrágio, in «Idem», n. ${ }^{\circ} 16$, Junho, 1878, p. 65, col. 2.

(2) Desenvolveremos esta questão no nosso estudo Republicanismo e Positivismo no pensamento e acção de Manuel Emidio Garcia.

(3) "Nas soluções políticas a obra mais segura é a que se faz pela indicação dos costumes modificados segundo as noções novas que se generalizam em sociedade. Os que lisongeiam exclusivamente a estabilidade dos costumes são os conservadores, que se fortalecem com esse automatismo espontâneo dos povos; os que procuram realizar as noções abstractas do progresso saem da utopia para o campo revolucionário. Pelo critério positivista se estabelece o acordo entre a conservação e a revolução" (Teófilo Braga, Historia das Ideias Republicanas em Portugal, p. 3). 
todos os doentes às condições agitantes de uma mesma cura que tanto pode ser salutar como funesta? Pois bem, os revolucionários sistemáticos são precisamente os médicos ignorantes do organismo social. Conhecem apenas os recursos» (1).

Poder-se-á pensar que a aceitação do princípio darwinista da selecção natural teria servido de ponto de partida a uma concepção agónica da sociedade que, directa ou indirectamente, apresentasse a luta de classes como motor da história. Contudo, apesar de alguns esforços interpretativos contemporâneos, uma das preocupações fundamentais do positivismo foi recalcar as contradições da sociedade capitalista em nome de uma filosofia da história de cunho idealista. A sociedade encontrava o seu motor determinante na evolução espontânea do espírito da Humanidade e as contradições mais não eram do que momentos necessários para a realização do estado positivo e do sistema científico-industrial anunciado pela lei dos três estados (2).

É dentro desta ordem de ideias que temos de equacionar o modo

(1) Júlio de Matos, Blanquismo e Opportunismo, in «O Positivismo», n.o 1, II ano, Outubro-Novembro, 1879, p. 65. Um outro positivista escrevia: «Ora, o organismo social, como qualquer organismo animal, também tem as suas perturbações, as suas doenças, os seus casos perfeitamente caracterizados de teratologia. São estas perturbações de vária espécie, mas em tudo análogas [tendo em consideração a distância que medeia entre os objectos das duas ciências] às suas congéneres na Biologia. Assim, no corpo social manifestam-se doenças agudas: são as guerras, as revoluções, os golpes de força, etc.» (Consiglieri Pedroso, O Fortuito na História, in "O Positivismo", n. ${ }^{\circ} 1$, I ano, Outubro-Novembro, 1878, p. 16). Por sua vez, TEÓfILo defendia que, se «não existem revoluções na natureza e tudo se desenvolve por uma evolução lenta e imperecível o mesmo devia acontecer nas sociedades (Teófilo Braga, Systema de Sociologia, p. 3); veja-se também Historia das Ideias Republicanas em Portugal, pp. 311-312; cf. A. ComTe, Cours, vol. 4, p. 448, e LitTRÉ, Conservation, Révolution et Positivisme, pp. 84, 88, 255.

(2) «Os reaccionários apelam para a restauração religiosa e absolutista, queixando-se da liberdade dos liberais -, e pedem o obscurantismo. Os metafísicos ameaçam com a revolução, queixam-se do ultramontismo teológico e dos ultra-revolucionários -, e querem revoluções políticas e sociais. Nós, os evolucionistas, republicanos democratas, invocamos a renovação intelectual por meio do progresso e difusão das ciências positivas e do trabalho produtivo, apelamos para a dignidade individual, para a conservação e aperfeiçoamento da sociedade de família, para a vida e iniciativa particular e local, e para o amor da humanidade... O progresso na evolução virá natural e espontaneamente, como consequência necessária, sem resistência anacrónica e sem exageros revolucionários» (MANUel Emídio GaRCia, Portugal e a Politica Portugueza na Balança Scientifica da Europa, in «O Partido do Povo», 
como perspectivaram a realidade da luta de classes nas sociedades modernas. Sintomaticamente, para TEófILo o proletariado teria aparecido na cena social devido «....a causas fortuitas, como a introdução da cultura do milho, o comércio internacional por causa da bússula, e a descoberta da pólvora, que acabou com o previlégio da bravura» (1). Por outro lado, a burguesia era definida como a camada mais antiga do proletariado. Portanto, o proletariado recente, longe de a combater, deveria lutar para ascender ao seu nível intelectual, moral e económico (2).

Adiante analisaremos as concretizações económico-sociais deste solidarismo de classe, o qual, diga-se, servia optimamente à propaganda republicana que visava construir um movimento não de uma determinada classe, mas de todos os cidadãos. Para já, interessa-nos sublinhar que viram a luta ascensional do proletariado à luz da filosofia da história comteana - a evolução do espírito como factor determinante e do princípio da selecção natural.

Por isso, Horácio Ferrari perguntava e respondia na óptica conciliadora e paternalista que caracterizou a posição do nosso republicanismo perante as classes trabalhadoras: "Quando triunfará definitivamente o proletariado? Quando for mais útil do que a burguesia

n. ${ }^{\circ}$ 8, Abril, p. 33, col. 3. Por sua vez, Teófllo escrevia: «É por isso que, segundo a concepção positiva de Comte, todo o progresso começa pelo desenvolvimento intelectual, que actua sobre o desenvolvimento moral convertendo e modificando os actos estáticos em opiniões, e por último, cooperando ambos estes factores para o desenvolvimento económico» (Teófilo BraGa, Historia das Ideias Republicanas em Portugal, pp. 305-306).

(1) O horizonte polémico do positivismo levava-os a reconhecer que a questão social era o problema mais importante do séc. XIX. Veja-se Té́filo Braga, Bases Positivas das Theorias Socialistas, in "O Positivismo", n. ${ }^{\circ}$ 2, I ano, Dezembro-Janeiro, 1879, pp. 85 e ss.; Horácio Ferrari, Evolução do Proletariado, in «O Positivismo", n.o 3, II ano, Fevereiro-Março, 1880, pp. 173-181.

(2) «A solução do problema da miséria está implícita nesta via [sociedade da abundância]. Por outro lado, o proletariado da Idade Média, pela sua moral, pela sua actividade, pela heterogenia dos seus talentos criou riqueza, fez-se útil, afirmou a sua superioridade em todas as formas de actividade humana; a esta situação nova deram os halucinadores socialistas o nome de burguesia, pensando deshonrar com a mesquinhez de origem essa parte do proletariado que avançou mais depressa e a quem compete pela sua intervenção no governo pelo princípio electivo, tornado efectivo na República, facilitar o advento ao bem estar social a essa parte atrasada do proletariado a que se chamou, com intuito de rebelião, o quarto estado» (TEÓFILo BraGA, Historia das Ideias Republicanas em Portugal, p. 291). 
na elaboração do progresso humano; ou, em termos mais precisos, quando os proletários valerem mais do que os burgueses em moralidade cívica e doméstica e em cultura intelectual; o que quer dizer, em linguagem biológica, que o organismo é mais perfeito que o dos outros na harmonia e proporção das suas propriedades e qualidades... Este processo é necessariamente lento, como lentas são as transformações que se passam em qualquer organismo, dentro do plano da sua evolução... A burguesia não suplantou de salto a classe nobre.... Ao aperfeiçoamento gradual, harmonioso, evolutivo do organismo dos burgueses, foi correspondendo o melhoramento das suas condições sociais... Uma série análoga de opções íntimas terão de sofrer os proletários; a diferença consistirá na duração relativa, em relação com a distância que separa, termo médio, o proletário do burguês, e com os meios que a civilização tem criado para se conseguir o aperfeiçoamento dos indivíduos. Demais, hoje é a própria burguesia quem promove convenientemente a elevação dos proletários, estabelecendo o ensino elementar obrigatório, as escolas profissionais, as escolas-asilos, as bibliotecas popula es, os museus públicos, os estabelecimentos de crédito a juro módico e para pequenas quantias, os bairros operários nas melhores condições económicas e higiénicas, etc.» (1).

Sendo assim, como assinalava Teófilo, para os positivistas republicanos, a luta de classes não passava de uma invenção metafísica (2). $\mathrm{Na}$ linha do pensamento burguês, o horizonte político dos nossos positivistas republicanos centrava-se na luta pacífica por uma democracia formal, laicizada e descentralizada, defensora dos valores essenciais da ordem capitalista e dos interesses particulares das camadas intermédias da sociedade. Em termos político-administrativos, isto implicava não só a rejeição do modelo totalitário de Estado defendido pelo CoMTE do Système, como permitia ainda, como veremos, lançar algumas reivindicações programáticas que, traduzidas num vocabulário ambíguo (Associacionismo, Socialismo), tocavam de perto a sensibilidade das camadas populares passíveis de serem doutrinadas pelas correntes socialistas. Por isso, escudando os interesses das classes médias no ideologismo cientista, Horácio Ferrari perguntava em 1880: "Abrangendo assim de um

(1) Horácio EsK Ferrari, art. cit., pp. 178-179.

(2) «O conflito do capital com o trabalho é um preconceito da escola clássica da Economia Política, que desconhece a coordenação dos factores sociais» (TEófilo Braga, Historia das Ideias Republicanas em Portugal, p. 285). 
relance toda a evolução do proletariado, poderá alguém entrever desapaixonadamente, nas suas tentativas de emancipação, a ruína da sociedade, o retrocesso da espécie humana? Não o cremos. Será pelo menos prejudicado o bem estar das classes superiores? Não, em relação aos seus membros que forem úteis, isto é, àqueles que concorrem com a sua actividade física e intelectual para a civilização.... Afinal a sociedade é um organismo em que os membros úteis se desenvolvem e aperfeiçoam, enquanto os inúteis se atrofiam e desaparecem, tal qual como nos organismos animais, seus elementos. O socialismo, pondo de parte todas as utopias e exageros, que revelam na maior parte dos seus apóstolos uma profunda anarquia mental, ou um deficiente conhecimento dos factos, e que provocam uma justa reacção da parte mais sensata e esclarecida da sociedade, tomado como expressão de um facto sociológico da ordem dinâmica, não é um perigo social nem um sintoma de regressão, é pelo contrário um indício de nova fase evolutiva da espécie humana, que se liga estreitamente com a marcha natural da sua civilização e que contribue, desde já, e contribuirá cada vez mais intensamente para o aumento do seu bem estar» (1).

O biologismo social culminava, assim, na apologética da conciliação e integração de todas as classes sociais. O evolucionismo, tendendo para uma crescente adaptabilidade dos indivíduos ao meio, traria, por um lado, o desenvolvimento e aperfeiçoamento dos membros úteis da sociedade; mas, por outro, levaria ao atrofiamento e ao desaparecimento dos seus membros inúteis. E como estes, em última análise, eram somente as camadas (aristocracia e clero) ligadas aos interesses da monarquia, a sua eliminação (por selecção natural), isto é, pacífica e eleitoralmente, possibilitaria a plena desenvolução do organismo social e a harmonização de todas as suas funções. Entrar-se-ia, portanto, no estádio definitivo da República, única forma de estado capaz de anular a luta de classes e fazer progredir a ordem liberal e capitalista.

(1) HoRÁcio ESK Ferrari, art. cit., pp. 180-181. 


\section{POSITIVISMO E DEMOCRACIA}

\section{Liberdade, Igualdade, Fraternidade}

Como vimos, a filosofia comteana não podia adequar-se à doutrina clássica da democracia, a qual, como se sabe, fundamentava a teoria do poder político partindo de uma concep̧̧ão voluntarista e atomista do indivíduo e da liberdade. Contudo, os nossos positivistas republicanos, ao declararem-se legítimos herdeiros da tradição liberal portuguesa, tiveram de integrar no seu pensamento os princípios fundamentais do democratismo burguês.

Mas, ao contrário do que acontecia nas teorias contratualistas do iluminismo, os conceitos de liberdade e de igualdade não podiam ser simplesmente deduzidos a partir da consciência individual. Assim, TeófILo BRAGA, sem dúvida aquele que expôs de uma forma mais sistemática o pensamento positivista neste domínio, justificava a clássica tríade da ideologia burguesa Liberdade, Igualdade e Fraternidade afirmando que a liberdade e a igualdade eram determinadas por impressões vindas do mundo exterior (1). Por outras palavras, os actos de liberdade seriam motivados por noções preponderantes no meio social e, assim, a igualdade mais não era do que a modalidade formal do mútuo exercício dessa liberdade. Simultaneamente, o conceito de fraternidade não era deduzido de qualquer pressuposto universal-racionalista, mas encontrava a sua base ôntica na cooperação orgânica e a sua expressão ética nos preceitos do altruísmo (2).

Por via diferente da argumentação racionalista justificavam, portanto, os mesmos princípios ideológicos. Quer isto dizer que o republicanismo positivista, mesmo descontando as críticas ao individualismo extremo e ao liberalismo exagerado, foi somente uma variante da ideologia democrático-burguesa. Prova-o o facto de o seu determinismo e antimetafisicismo ir desaguar, no campo programático, na invocação dos princípios formais em que se alicerçavam os programas políticos liberais. Teófilo Braga, por exemplo, do conceito de liberdade condicionada deduzia as formas concretas da sua expressão, as quais, em última análise, consignavam as chamadas liberdades fun-

(1) Veja-se Teófilo Braga, Systema de Sociologia, p. 143.

(2) Idem, p. 276. 
damentais do liberalismo «tout court» (1). Assim, segundo ele, a história ensinava que a evolução do espírito exigia a realização da liberdade individual nos níveis filosófico, politico e civil. À liberdade filosófica, corresponderiam as liberdades de consciência, de ensino, de imprensa e de cultos; à liberdade política, as de representação, reunião e associação; e à liberdade civil, a liberdade de propriedade, indústria, tráfico $e$ contrato $\left({ }^{2}\right)$.

Isto é, para os nossos positivistas, a consumação plena do reino da perfeição terrena dar-se-ia quando fosse instaurado um sistema político assente na "Igualdade civil e a Liberdade política na base moral da Fraternidade ou solidariedade humana» (3). Ou, dito de outro modo, dar-se-ia quando a igualdade formal conseguisse integrar as contradições resultantes da desigualdade real da sociedade capitalista.

\section{A importância da opinião pública}

Com a aceitação dos princípios da democracia formal e com a adesão às teses evolucionistas - fundamento da via pacífica para a República -, o positivismo republicano aproximava-se da chamada corrente do republicanismo democrático. Mas, se o poder político radicava nos princípios filosóficos típicos da democracia formal, qual era a modalidade da sua legitimação se, como sabemos, A. СомтE rejeitava tanto a teoria da soberania popular como o sufragismo universal?

A teleologia evolutiva das sociedades, ao colocar como seu motor último o curso espontâneo do espírito, tinha, forçosamente, de sobrevalorizar os fenómenos ligados à opinião pública que, como manifestação consensual de uma dada mundividência de classe, era uma realidade colectiva essencial ao funcionamento dos mecanismos de legitimação do poder em democracia burguesa. Ora a filosofia de COMTE continha uma coerente teoria da opinião pública e do senso comum, bem como da sua função cimentadora da totalidade social através da atenuação ideológica dos conflitos de classe (4). Daí a receptividade consciente que

(1) Idem, pp. 275-276. O mesmo se pode encontrar em MANUEL Emídio Garcia, Consiglieri Pedroso, Horácio Ferrari, e nos restantes positivistas.

(2) Compare-se esta posição com os vários programas republicanos de então.

(3) Té́filo Braga, op. cit., p. 276.

(4) «Os partidos - escrevera JúlIO DE MATOS em 1880 -, que são a consequência da indisciplina da metafísica, terão cessado de existir em política como 
os positivistas revelaram para as questões ligadas aos conteúdos e à função da ideologia na sociedade capitalista (1).

De facto, a produção de uma mundividência homogénea e laica, ou melhor, o fomento de uma consciência racional e de uma opinião pública que possibilitasse a constituição de um consenso entre as partes da sociedade, em ordem a aceitar-se a inevitabilidade da República e a permitir a integração do proletariado, era uma tarefa que se impunha para a consolidação e consequente alargamento da base social de apoio do republicanismo $\left({ }^{2}\right)$.

Aperceberam-se, por conseguinte, de que a democracia formal assentava na concorrência de opinióes expressas pelo voto. Por isso, tentaram demolir a posição hegemónica que a ideologia clerical ainda exercia ao nível da opinião pública e dos aparelhos ideológicos. Pondo os olhos na luta pela completa secularização do ensino que, entretanto, JULES FERRY levava a cabo em França, os positivistas republicanos sabiam que, sem uma actividade propagandística intensa e sem uma modificação radical nos conteúdos e no estatuto do ensino em Portugal, bem como nos meios de formação intelectual, seria impossível a modificação do senso comum e, consequentemente, a obtenção da maioria por sufrágio universal.

A esta luz, compreende-se a importância que a revista $O$ Positivismo deu às questões do ensino; ilumina-se a actividade poligráfica de TEÓFILO; explica-se a intensíssima rede jornalística que os republicanos conseguiram construir; compreende-se ainda a dimensão tribunística e didáctica que deram a toda a sua propaganda. É que, como notava Teófilo, eles sabiam que o século da democracia formal se distinguia dos tempos

cessaram em ciência, porque diante da demonstração não há lugar para duas opiniões diversas; as discussões irritantes do momento histórico que vamos atravessando acabarão enfim pela unanimidade de crenças a que a sociologia fatalmente conduzirá todos os cérebros e todos os corações» (Júlıo DE MATOS, A Reorganização da Politica pela Sciencia, in «Era Nova», p. 72).

(1) TeÓfILo chegou mesmo a escrever: «O bom senso natural é, de certo modo, um estado de positividade....» (Teófilo Braga, Systematização da Moral, in «O Positivismo", n. ${ }^{\circ}$ 3, II ano, Fevereiro-Março, 1880, p. 209).

(2) «Sob o aspecto científico a principal propriedade da Filosofia Positiva é a unanimidade de crenças reais e positivas que tende a estabelecer. Por unanimidade de crenças entendemos a generalização do mesmo ponto de vista filosófico ou científico, ou a coerência mental levada a todos os cérebros e a todas as regiões do globo, isto é, a mesma concepção do mundo....» (Teixeira Bastos, Comte e o Positivismo, p. 107). 
do absolutismo "pela manifestação de uma nova força social - a opinião pública, e para que essa força exercesse uma acção directa sobre os destinos da humanidade, era necessário que se convertesse, de simples aspiração que era, numa conviç̧ão racional e prática» (1). Para isso - alertava Manuel Emídio Garcia, em $O$ Positivismo -, havia que «....insistir por todos os meios, sem tréguas nem descanso, nem hesitaçð̃es, nem condescendências, para que a influência educadora das ciências e da filosofia positiva, que as reune e coordena, se generalize e penetre bem fundo em todas as camadas sociais e forme a opinião pública dominante em cada povo e na humanidade inteira» (2).

Com efeito, olhando para a situação ideológica do país, meio século depois do início da revolução política da burguesia, tornava-se evidente que o controlo exercido pelo clero sobre as consciências, quer através do quase monopólio do ensino primário e secundário, quer através do púlpito e da imprensa confessional, se tinha transformado num obstáculo à imposição hegemónica do domínio burguês em todos os níveis da estrutura social. Portanto, a par da reivindicação de um regime republicano, os positivistas pugnavam igualmente pela completa separação entre a Igreja e o Estado, bem como pela institucionalização do ensino público obrigatório (3). Isto é, lutavam pela secularização total das superestruturas político-repressivas e ideológicas do modo de produção capitalista. Só assim, se conseguiria a necessária adequação das instâncias reprodutoras com a infra-estrutura e, consequentemente, a intensificação do desenvolvimento das forças produtivas.

(1) Teófilo Braga, Historia das Ideias Republicanas em Portugal, p. 365.

(2) Manuel Emídio Garcia, A Instrução Secundária em Portugal, in «O Positivismo", n. ${ }^{\circ}$ 6, Agosto-Setembro, 1880, p. 473.

(3) De facto, como se poderá ver no nosso estudo sobre MANuel Emídio GARCIA, foi acérrima a luta entre os republicanos, que pugnavam por um ensino obrigatório e dominantemente estatizado, e a Igreja, que defendia o ensino facultativo e livre. Compreende-se esta adesão da hierarquia às teses do liberalismo. É que, instaurando-se a livre concorrência neste campo, a Igreja, dada a posição dominante que ainda ocupava e as possibilidades que tinha de humana e institucionalmente continuar a ministrar o ensino público, impediria, na prática, que o sector laico viesse a desempenhar o papel hegemónico que os movimentos liberais, republicanos e socialistas reivindicavam. 


\section{As comemorações camonianas}

Por outro lado, também a transformação do Partido Republicano de um agrupamento regional e intelectualista num movimento de vocação nacional passava pela coesão doutrinal dos seus membros e pela possibilidade da sua mensagem política chegar, de um modo acessível, às camadas sociais que o seu projecto político visava captar trabalhadores e pequena e média burguesia. Daí a ênfase que puseram na importância da propaganda. E, sintomaticamente, foi neste contexto que surgiu o acontecimento mais importante para a realização de tais objectivos: as comemorações camonianas.

É uma verdade indesmentível dizer-se que as festividades se desenrolaram sob a inspiração da filosofia positivista. Para o constatarmos, basta invocar a filiação doutrinária dos seus principais animadores: Teófilo e Ramalho Ortigão e, em Coimbra, Manuel Emídio Garcia, todos positivistas. A presença do positivismo nota-se, mesmo, na estrutura e na intenção das próprias celebrações.

O contexto político em que a ideia surgiu é conhecido: os republicanos assenhorearam-se da figura do Épico, símbolo de um período áureo da nossa história ( $\left.{ }^{1}\right)$, para que, em contraponto e de um modo pragmático, pudessem mostrar o estado de decadência económica (as crises do capitalismo nacional e internacional faziam-se sentir entre nós com bastante agudeza), política e intelectual, provocado pela política monárquica das últimas centúrias. Como é óbvio, as comemorações não surgiram directamente como uma manifestação de cunho político. Contudo, outra não era a intenção dos principais promotores e outro não foi o seu efeito sobre a opinião pública, vindo a efeméride a saldar-se num êxito estrondoso para o Partido Republicano.

Como se sabe, a ideia do enaltecimento das figuras e acontecimentos decisivos no aperfeiçoamento político, científico, cultural e moral da humanidade foi uma das notas essenciais da ética positivista e situava-se na linha do antropocentrismo que está na base de todo o sistema. $\mathrm{O}$ homem, ou melhor, a Humanidade surgia como um indivíduo suces-

(1) «O Centenário de Camões manifestou à Europa que sabíamos tirar da maior tradição do nosso passado histórico o estímulo para um renascimento» (TEófilo Braga, Historia das Ideias Republicanas em Portugal, p. 356). 
sivamente melhorado através da acção dos povos, incarnada nas obras e nos actos dos indivíduos. A ontogénese coincidia, portanto, com a filogénese, e o tempo histórico, na linha da concepção evolucionista, era apresentado como contínuo. Por isso, a educação do presente, se devia ter em vista o futuro, tinha igualmente de pautar-se pelos grandes exemplos do passado. Daí que, para CoMTE, os mortos devessem comandar os vivos, o que levou à entificação da Humanidade - o Grande Ser - e à sua consagração numa sociolatria perfeitamente dogmatizada e ritualizada. A Religião da Humanidade, com um Deus simultaneamente transcendente (em relação ao passado e ao futuro) e imanente (para os indivíduos do presente) e com o seu sacerdócio, os seus santos, as suas orações, preparava-se para ser a religião adequada ao desenvolvimento científico-industrial e, assim, substituir o catolicismo das sociedades contemporâneas.

O positivismo em Portugal não seguiu na senda dos sociolátricos (1). No entanto, a receptividade aos fenómenos ideológicos (2) convenceu-os de que uma dominação de classe seria impraticável sem a presença de uma concepção do mundo capaz de conferir coesão e atenuar os conflitos sociais e, assim, garantir a reprodução das relações de produção capitalistas $\left({ }^{3}\right)$. Consequentemente, para além da luta pela renovação do

(1) Para os nossos positivistas, a religião da humanidade era "o produto de uma imaginação enferma" (Teixeira Bastos, Comte e o Comtismo, p. 53); veja-se também, do mesmo autor, As Revoluções Sociais nos seculos I e XIX, «Era Nova", p. 125.

(2) «Não acompanhamos a concepção sociológica de Comte quanto às suas formas religiosas, mas reconhecemos que nas sociedades modernas alguma coisa se passa que, tendendo a satisfazer necessidades de sentimento, vai ao mesmo tempo substituindo as religiões» (Teófilo Braga, Systema de Sociologia, pp. 16-17).

(3) O feudalismo, devido às relações de não separação entre os agentes produtivos e os meios de produção (o que exigia mecanismos de coacção extra-económicos para que o trabalhador entregasse o excedente do seu trabalho), encontrou no catolicismo a forma concreta da ideologia dominante necessária à reproduçăo das relações sociais feudais. SAINT-Simon com o seu Novo Cristianismo e A. Comte com a sua religião da Humanidade tentaram um projecto impossível: inventar uma religião que estivesse para a sociedade industrial como o catolicismo tinha estado para a Idade Média. Debalde, porque não se aperceberam das consequências ideológicas decorrentes da natureza das novas relações de produção: devido à separação entre os agentes produtivos e os meios de produção, os indivíduos tornaram-se «sujeitos-livres» e, por isso, na sociedade capitalista, a reprodução passou a dar-se sem o recurso directo e constante a factores extra-económicos. O trabalhador, tendo de seu somente a força de trabalho, vende-a «livremente» e «livremente» dá 
ensino em moldes científicos e da proliferação de órgãos de comunicação, em lugar de se lançarem na estulta tentativa de implantarem em Portugal uma nova religião, como fizeram alguns positivistas brasileiros, procuraram antes compatibilizar os conteúdos do cristianismo primitivo e a função da Igreja com o progresso científico e com a democracia e ganhar a hegemonia espiritual, a qual, contra СомтE, não deveria ser exercida por uma casta ou seita dogmatizada, mas, pelo contrário, e à boa maneira liberal, pela acção legitimadora e vigilante da opinião pública.

Foi dentro desta ordem de ideias que surgiram as comemorações de CAMÕES, réplica dos positivistas portugueses às celebrações centenárias em honra de Rousseau e Voltaire (1). Ao que se sabe, a ideia partiu de Teófilo. Pelo menos, já em 1879, inspirando-se no pensamento comteano, a defendia acérrima e pormenorizadamente nas páginas da revista $O$ Positivismo (2).

o direito ao capitalista de se apropriar da mais valia. A ideologia religiosa tende a perder a sua posição dominante a favor de outras formas mundividenciais mais adequadas à nova estrutura social. Esta, devido ao papel da economia no modo de produção capitalista, simultaneamente instância determinante e dominante, corporiza-se em valores ligados ao saber-fazer científico e industrial e no formalismo jurídico. Assim, a Família, a Escola e os órgãos de comunicação subalternizaram gradualmente a Igreja.

(1) Em 1878, Júlio DE MATos, um dos principais animadores das Comemorações no Porto, escrevia: «Registamos com prazer uma confissão prática da nossa opinião: as festas públicas dos centenários de Voltaire e Rousseau. Que significam estas demonstrações senão que o Humanismo [leia-se: Positivismo] penetrou já a consciência dum dos mais adiantados países da Europa?». (Júlıo DE Matos, A Religião do Futuro, in "O Positivismo», n. ${ }^{\circ} 1$, I ano, Outubro-Novembro, 1878 p. 69). Também a conferência de Teófilo a propósito do Centenário de Voltaire está perpassada de uma visão positivista das Comemorações. Veja-se Teófilo Braga, Voltaire - Conferência Pública para celebrar o primeiro Centenário de Voltaire no Grémio Operário de Lisboa, em 30 de Maio de 1878, in «O Positivismo", n. ${ }^{\circ}$ 5, II ano, Junho-Julho, 1879, pp. 325-349, e Os Centenarios, Porto, Typ. de A. J. da Silva Teixeira, 1884, pp. 69-161; Historia das Ideias Republicanas em Portugal, pp. 365 e ss.; Era Nova, in «Era Nova», p. 2.

(2) Veja-se Teófilo Braga, $O$ Centenario de Camões em 1880, in «O Positivismo", n. ${ }^{\circ}$ 1, II ano, Outubro-Novembro, 1879, pp. 1-9. Pode considerar-se este artigo como o primeiro em que TÉ́fiLo defendeu a ideia e o esboço do programa das Comemorações. Alexandre Cabral, no seu estudo sobre o Centenário de Camões, não regista o facto, nem sequer tira dele as devidas implicações filosóficas. Cf. AleXandre Cabral, Notas Oitocentistas, Lisboa, Plátano Editora, 1973, p. 103. 
E, tal como os seus correligionários franceses, o que lhes interessava era explorar uma forma ritualista através da qual, sem envolver qualquer dimensão de culto dogmatizado, pudessem veicular a nova visão do mundo e provocar os efeitos políticos que lhe eram inerentes. Deste modo, JÚLIO DE MATOS podia afirmar no dia 10 de Junho de 1880: «Sendo assim, nós, ao fixarmos respeitosamente a marcha secular das sociedades, nem divinizamos a humanidade, substituindo-a ao velho mito religioso, nem, celebrando o centenário dos homens eminentes, os santificamos, fazendo do Pantheon um simulacro das catedrais cristãs. Não! Em ocasiões como estas, nós apenas manifestamos a coerência do coração com o espírito. O espírito demonstra-nos a solidariedade humana e a acção beneficiente, embora limitada, dos homens superiores; o coração sente-se simpática e respeitosamente comovido, docemente estimulado às mais generosas acções. É segundo esta doutrina que se chama Humanismo, é à luz desta concepção sistemática que nós vemos o $3 .^{\circ}$ centenário de Camões» (1).

Do ponto de vista filosófico, idêntica era a fundamentação apresentada por Teófilo. Cônscio da crise ideológica do capitalismo, sabia também que a solução não estava no recurso a uma nova religião; haveria sim que encontrar uma espécie de sucedâneo que cumprisse a função religadora própria da ideologia e particularmente das religiões. Assim, não deixava de assinalar que, embora não acompanhasse «a concepção de Comte enquanto às suas formas religiosas», reconhecia que «nas sociedades modernas alguma coisa se passa, que tendendo a satisfazer necessidades do sentimento, vai ao mesmo tempo, substituindo as religiões.

(1) Júlo De Matos, Significação Philosophica e Social das Festas do Tricentenário de Camões, in "O Positivismo», n. ${ }^{\circ}$ 5, $1 \mathrm{l}$ ano, Junho-Julho, 1880, p. 398. No número seguinte, TEÓfILo reforçava o enquadramento positivista das festas e o seu carácter não dogmático, em contraste com a teoria comteana da Religião da Humanidade: «As comemorações dos grandes tipos da humanidade foi particularizada por Augusto Comte em cerimónias sociolátricas, que foram imobilizar-se no formalismo de uma religião demonstrada; o que havia de profundo e verdadeiro na concepção foi aproveitado pela civilização europeia, nas festas nacionais dos Centenários, como o de Spinosa, de Rubens, de Voltaire, de Petrarca, rendendo-se assim a livre expansão do génio de cada povo» (Té́filo Braga, $O$ Centenario de Camões no Brazil, in "O Positivismo", n. ${ }^{\circ}$ 6, II ano, Agosto-Setembro, 1880, p. 513). Veja-se também Manuel Emídio Garcia, Estudo Sociológico, pp. XVIII-XXI, e As Comemorações Civicas em Honra e para Glória da Humanidade, in Francisco XAvier Esteves, "Album Litterário Commemorativo do terceiro centenario de Luiz de Camões», Porto, Typ. Occidental, 1880, pp. 17-19. 
A síntese activa está sendo realizada espontaneamente nas Exposiçð̃es; a síntese afectiva, correspondendo às noções de solidariedade humana manifesta-se pelos Centenarios dos grandes homens ou dos grandes sucessos; a síntese especulativa como reconhecimento geral do poder espiritual da Ciência, efectua-se por meio dos Congressos, em que a pátria se alarga na humanidade» (1).

$\mathrm{Na}$ verdade, os republicanos procuravam algo que não ousavam confessar: uma espécie de vivência cívica formalizada em termos de movimentação religiosa. Assim, a estruturação das comemorações e respectiva simbologia mais não foram do que uma secularização das festividades católicas. Daí a sua adequação aos objectivos que visavam: se é «à filosofia positiva em Portugal que se deve a ideia da selebração do Centenário de Camões, em 1880, a compreensão da festa,

(1) Teófilo Braga, Systema de Sociologia, p. 16-17 e Os Centenarios, pp. V-VI. A argumentação de MANuEl EMíDIo Garcia inscreve-se na mesma fidelidade ao espírito da filosofia comteana. Assim, escrevia: "A mais bela criação social da Filosofia Positiva, produto espontâneo e inevitável da concepção verdadeira e real do mundo, é a organização de um vasto plano de comemorações destinadas a glorificar as diversas fases sucessivas da evolução da Humanidade e os principais motores dos respectivos progressos, apreciados conformemente à sã teoria dinâmica da Humanidade, - extremo vértice na hierarquia dos seres, ponto de vista para todas as ciências, síntese a mais culminante e sublimada, até onde a observação, a experiência e o raciocínio podem alevantar o espírito nas suas indefinidas e insaciáveis aspirações científicas, e para além da qual só encontramos, arrastados pela imaginação, os fantasiosos sonhos do infinito que nos atormentam, o pesadelo de eternidade que nos apavora, a ciência sem objecto, o absoluto sem realidade. Uma tal instituição, sabiamente concebida e judiciosamente delineada por A. Comte, não só corresponde à necessidade especulativa e prática de exercer uma elevada vigilância sobre o movimento progressivo do espírito humano, relacionando e coordenando as suas concepções, a fim de sistematizar os seus produtos, mas servirá também e principalmente para instituir e vulgarizar uma certa ordem de hábitos morais, públicos e particulares, capazes de manter sempre vivo e inesgotável, quando frouxo e decadente, o sentimento altruísta da solidariedade social, indissoluvelmente ligado à continuidade histórica tão própria e característica da nossa espécie. A instituição de um tal sistema de comemoração universal poderá proporcionar, além disso, uma grande utilidade intelectual e moral, popularizando a ciência e a indústria por meio do exemplo persuasivo e educador, poderosos estímulos e motivos às determinações da vontade, desenvolvendo e aperfeiçoando os sentimentos altruístas, que são um verdadeiro produto social, no espírito das multidões" (Manuel Emídio Garcia, As Comemorações Cívicas em Honra e para Glória da Humanidade, p. 17, cols. 1-2). Veja-se também Teixeira Bastos, Comte e o Positivismo, p. 120. 
o modo de dar coerência à espontaneidade emocional do povo, a hostilidade dos poderes empíricos, o espírito democrático dessa manifestação secular, tudo revela uma nova orientação da consciência portuguesa»; o seu resultado último, contudo, «significou uma coisa: que este povo é capaz de se mover por uma ideia. Não está morto como o julgavam, aqueles que o ludibriavam sangrando-o pelo imposto, vendendo-o pelos empréstimos, matando-lhe o trabalho e desmembrando-lhe o território por tratados fraudulentos» (1).

Por outras palavras, a intenção básica das comemorações foi a de reforçar a luta contra a monarquia e o ultramontanismo: «A festa do Centenário - assinalava Júlio DE MATOS - tem sobretudo esta alta significação política. Camões, cantando a pátria nos seus dias de glória e morrendo com ela nos seus dias de miséria e opróbio, é para nós o espírito que melhor representa o povo português. Saudar esse homem é, primeiro que tudo, lavrar um protesto contra a atonia em que nos lançaram o elemento monárquico, é significar que não abdicamos da dignidade do povo livre, é declarar que entrámos na fase consciente da política democrática» $(2)$.

De facto, os efeitos das comemorações - que se estenderam às principais cidades - repercutiram-se na vida política do país e trouxeram uma estrondosa vitória para o campo republicano, pois intensificaram o processo de unificação interna do movimento que, assim, conseguiu identificar-se com um projecto nacional e nacionalista, capaz de tocar de perto a sensibilidade e os interesses das classes intermédias da sociedade portuguesa finissecular.

\section{Legitimação do poder e sufrágio universal}

A aceitação dos princípios formais de legitimação do poder político não deixava de entrar em choque com algumas das bases filosófico-políticas do sistema de A. ComTE. É que o democratismo implicava aceitar que toda a fonte do poder radicava no indivíduo, que o poderia

(1) Teófilo Braga, O Centenario de Camões no Brazil, in «O Positivismo», n. ${ }^{\circ}$ 6, Il ano, Agosto-Setembro, 1880, p. 513.

(2) Júlio De Matos, Significação Philosophica e Social das Festas do Tricentenario de Camões, p. 399 . Veja-se também Té́filo Braga, As Comemorações, pp. 53, 55, 59, e Manuel Emídio Garcia, Discurso (proferido na Sala dos Capelos, no dia 10 de Junho de 1880), in "O Instituto», vol. 27, pp. 585-599. 
delegar em representantes por si escolhidos. Quer isto dizer que a teoria da soberania e do sufrágio assentava numa explicação individualista e metafísica, ou melhor, contratualista, que nada tinha a ver com o pensamento do autor do Cours.

Para Comte, tal doutrina não passava de uma inversão da teoria do direito divino: em lugar de Deus colocava-se o homem. Isto é, assentando a doutrina na capacidade optativa do sujeito individual, negava-se o estatuto de sujeito colectivo - visível no fenómeno da opinião pública - e recuperavam-se as teses metafísicas do livre arbítrio. Daí que escrevesse: «en appréciant, comme il convient, l'indispensable office transitoire de ce dogme révolutionnaire, aucun vrai philosophe ne saurait méconnaître aujourd'hui la fatale tendence anarchique d'une telle conception métaphysique, lorsque, dans son application absolue, elle s'oppose à toute institution régulière, en condamnant indéfiniment tous les supérieurs à une arbitraire dépendance envers la multitude de leurs inférieurs, par une sorte de transport aux peuples du droit divin tant reproché aux rois» (1).

De facto, para o autor do Cours, a legitimação do poder não estava no sufrágio, mas na capacidade científico-industrial dos indivíduos. Daí que a sua sociologia culminasse numa sociocracia. Como se compreende, tal posição - levada às últimas consequências no Système impossibilitava qualquer adequação do comtismo à democracia formal. Por isso, o sector progressista dos seus discípulos teve de operar uma revisão a este dogma positivista. Assim, primeiro Wyrouboff a depois LITTRÉ, vieram a perfilhar os princípios da soberania e do sufrágio, no que eram ajudados pelas influências do positivismo inglês - SPENCER e Stuart Mill - , sem que isso, contudo, implicasse o reconhecimento do valor filosófico desses princípios. Fizeram-no tão só em nome das vantagens políticas que deles advinham no combate contra o bonapartismo e na consolidação da III República ( ${ }^{2}$ ).

(1) А. Сомте, Cours, vol. 4, pp. 55-56. Sintomaticamente, Teófilo justificava o sufrágio universal como uma consequência da individualização provocada pela heterogeneidade coerente (SPENCER) característica dos fenómenos complexos: "Assim de uma heterogenia orgânica e diferença de hierarquia se produziu essa coerência ou vínculo jurídico conhecido na civilização normal como uma coisa normal: a igualdade civil, que tende a completar-se no sufrágio universal, a manifestação definitiva da Democracia» (Teófilo Braga, Systema de Sociologia, p. 39).

(2) MANUEl Emídio GaRcia relacionava os conceitos de soberania e de sufrágio deste modo: "Admitindo bem ou mal, o dogma da soberania popular, imposta 
A posição dos positivistas portugueses não deixou de revelar esta contradição entre os princípios da filosofia e as necessidades da militância política. Ainda em 1876, Consiglieri PEDroso, no seu opúsculo O Sufrágio Universal ou a intervenção das Classes Trabalhadoras no Governo do País, talvez influenciado pelo opúsculo de TAINE, Le Suffrage Universel, defendia o sufrágio universal em termos jusnaturalistas: «Parece-nos ter demonstrado clara e irrefragavelmente - escreve pela análise dos direitos humanos, e pelo eloquente exemplo da história, que o sufrágio universal é não só um direito incontestável, anterior e superior a toda a legislação, mas também, e principalmente, um dos fiadores mais seguros da propriedade de um povo, uma das prevenções mais eficazes contra esses fracassos sociais, que se chamam revoluções» (1).

O sufrágio surgia, assim, não só como uma necessidade decorrente de um princípio filosófico, mas também motivado por uma intenção política. De facto, os republicanos tinham vantagem em lutar pela sua consignação na lei - transformação do dircito natural em direito positivo - por dois motivos: por um lado, contestavam o esquema censitário em que se baseava a legitimidade do poder legislativo constitucional; por outro lado, a extensão do direito do voto às classes trabalhadoras seria uma medida premonitória contra o socialismo e o republicanismo revolucionários. Daí que Consiglieri Pedroso escrevesse: «...é no interesse das próprias classes conservadoras que

pela força das circunstâncias, trazido fatalmente, embora no meio das agitações e das tempestades revolucionárias, como um produto da evolução científico-industrial, ficou definitivamente estabelecido e positivamente sancionado um princípio, uma suprema lei política, cujos efeitos ou consequentes lógicos ninguém hoje se atreveria, de boa fé, a contestar. Se tudo deriva da soberania da nação, se é ela a única base da sua organização administrativa, fonte de todo o poder, origem e sanção de toda a autoridade legítima, é evidente e irrecusável que a nação tem direito de manifestar os seus sentimentos, de exprimir as suas ideias, de declarar a sua vontade e impor as suas deliberações... E como poderá fazer-se essa expressão da soberania popular, essa declaração solene da vontade de todos a não ser por meio do sufrágio universal? Se a soberania popular é a lei suprema, o suffragio universal é o único meio de afirmar e praticamente verificar a existência real e positiva dessa lei» (MANuEL Emído GaRCIA, Porque e como aceitamos o Suffragio Universal, in "O Partido do Povo", n. ${ }^{\circ} 16$, Junho, 1878, p. 65, col. 1).

(1) Consiglieri Pedroso, $O$ Suffragio Universal ou a Intervenção das Classes Trabalhadoras no Governo do Paiz, Lisboa, Nova Livraria Internacional, 1876, pp. 32-33. 
nós pedimos hoje o sufrágio universal. Deviam ser elas, se não fosse uma inexplicável cegueira que as domina, as primeiras a concedê-lo, antes que lhes fosse arrancado por esse novo direito, selado com o sangue de todos os mártires deste século - que se chama o direito das revoluções» (1).

Pelo que conhecemos, julgamos que foi MANUEL Emídio Garcia o primeiro positivista português que se apercebeu da incompatibilidade existente entre os princípios democráticos e a ortodoxia positivista. A reivindicação do sufrágio universal era uma das questões fundamentais para o republicanismo democrático. Por isso, os positivistas «sem discutir o princípio -, como sublinhava GARCIA em 1878 - embora na sua origem o considere revolucionário crítico, e aceitando o sufrágio universal como facto adquirido ou como ensaio sociológico, levados eminentemente pela indução e tendo por critério a experiência, tratam de facilitar a sua realização prática, de modo que o exercício de direito correspondente se proporcione, no seu modo de realização à capacidade intelectual e ao merecimento moral dos indivíduos, harmonizando-os, quanto possível, com as circunstâncias do estado social dominante» (2).

O sufrágio universal só poderia ser uma conquista favorável aos intentos dos republicanos evolucionistas, pelo que aderir ao dogmatismo doutrinal seria revelar incapacidade pragmática ao nível da luta política. Por conseguinte, escrevia o lente positivista: «...pouco nos importa as razões que o podem legitimar ou condenar aos olhos dos filósofos ou dos partidos. Essas razões não alteram o seu carácter essencialmente democrático, nem modificam o seu valor eminentemente

(1) Idem, p. 22.

(2) Manuel Emído Garcia, Porque e como Aceitamos o Suffragio Universal, in «O Partido do Povo», n. ${ }^{\circ}$ 16, Junho, 1878, p. 65, cols. 2-3; veja-se também, A Reforma Eleitoral e o Partido Republicano, in «O Partido do Povo», 1878, n. ${ }^{\circ}$ 14, p. 57, cols. 1-3. Teófilo BragA, sem discutir em termos positivistas a questão da soberania e colocando-se inequivocamente na linha de STUART MILl, escrevia em 1882: «....se os indivíduos que compõem uma sociedade são livres pela sua racionalidade, essa sociedade deve ser governada pelo conjunto dessas vontades livres, isto é, a Autoridade há-de, logicamente, derivar-se da delegação de todos esses elementos iguais, e constituir a expressão da sua mútua harmonia. Assim, a compreensão do individualismo na forma política do Self-government corresponde à compreensão do Estado como realização da Soberania Nacional» (Teórilo BraGA, Marcha da Politica Europêa, in «O Positivismo», n. ${ }^{\circ} 4$, IV anno, Julho-Agosto, 1882, p. 273). Veja-se também Historia das Ideias Republicanas em Portugal, pp. 211 e 216. 
republicano» (1). Deste modo, «atacar uma instituição que se impõe, que se torna indeclinavelmente necessária em virtude das próprias condições do nosso organismo político, seria, além de inútil, um contra-senso, um erro indesculpável; seria, no prudente dizer de WyroubofF, não compreender as leis que regem o movimento ascendente e evolutivo das sociedades" (2).

Compulsando os textos dos positivistas republicanos, bem como as bases programáticas do Partido, é facto incontroverso que a reivindicação do sufrágio universal se tornou um dos cavalos de batalha da propaganda republicana. Consequentemente, só operando uma revisão das teses antidemocráticas de COMTE o positivismo poderia adequar-se ao republicanismo democrático.

\section{Politica e Ciência}

As pretensões do positivismo, ao nível político, não se reduziam, contudo, a meras sugestões programáticas. A sua política estava equacionada em termos cientistas, pois a função última da Sociologia seria munir os governantes com as leis da fenomenalidade social, de modo a conseguir-se uma acção racional capaz de superar as crises do capitalismo, o que, segundo os positivistas, só seria possível se as suas determinações possuissem um estatuto de objectividade que conseguisse, tal como as ciências da natureza, congregar a unanimidade de todas as opiniões. Como escrevia Júlio de Matos, «sairão da classe dos sociologistas, os parlamentares das sociedades futuras. Os Bismark, os Canovas, os Bieconsfield, serão substituídos por homens como Littré e Spencer» (3). Para isso, a política tinha de assumir o estatuto de uma ciência social, isto é, como assinalava СомтE, era preciso que: «leur caractère soit large et leur destination éminemment populaire, au lieu de se rapporter à des intérêts partiels et antisociaux; il faut enfin que la politique y soit directement relative au propre essor de l'esprit positive, quand il sera assez complétement formé pour mériter d'être

(1) Manuel Emídio Garcia, A Reforma Eleitoral e o Partido Republicano, in «O Partido do Povo», n. ${ }^{\circ} 14,1878$, p. 37, cols. 2-3.

(2) Idem, col 2.

(3) Júlio de MAtos, A Reorganização da Politica pela Sciencia, in «Era Nova», 1882 , p. 73. 
habituellement envisagé comme le régulateur mental des sociétés modernes» (1).

Esta preocupação, nitidamente saint-simoniana vai ser continuada pelos discípulos de A. CoмтE. Assim, para a escola heterodoxa, a política surgia como uma ciência social particular. No autor do Système, a sociologia reduzia-se, em última análise, a uma política, isto é, não havia lugar para as divisões internas dentro do seu espaço epistemológico. A tarefa dos seus continuadores foi não só reconhecerem o estatuto científico de novos domínios do saber - psicologia, etnologia, linguística - (o que tinha sido negado por COMTE), como admitirem a necessidade de se encontrarem leis particulares dentro da esfera geral da sociologia.

Contra a concepção rigidamente aristotélica de COMTE, tentou-se fundamentar a existência de ciências sociais regionais, onde a sociologia surgia como a ciência sintética que, enquanto explicação da totalidade social, englobava as leis gerais da estática e da dinâmica. Por sua vez, a política, nela fundamentada, emergia com um conjunto de regras e leis da governação possuidoras de uma «verdade» própria das ciências já constituídas. Bastava tão só aplicar ao seu objecto a metodologia da experimentação, da comparação e da filiação; por outras palavras, a metodologia da ciência social geral.

Também os positivistas portugueses se empenharam na tarefa de cientificar a política. Compreende-se. A argumentação cientista pesava fortemente na balança da luta política. Assim, não se estranha que o maior ideólogo do republicanismo de então tenha escrito: «Coube ao século XIX a missão de completar o quadro das ciências cosmológicas e biológicas com o novo grupo das ciências sociológicas, e estabelecendo-se a mútua dependência entre elas, relacionaram-se pelas dẹuções das leis gerais, constituindo-se um conhecimento novo, esse espírito de conjunto que as disciplina - a Filosofia positiva, esboçada pelo génio de Augusto Comte. A criação da Sociologia só foi possível depois dos progressos fundamentais da biologia no princípio deste século, e depois da especialização de um grande número de ciências concretas formadas pela investigação de dados fenómenos sociais. Diante desta concepção geral, a política torna-se uma ciência de aplicação, como a agrimensura em relação à matemática, a pilotagem em

(1) А. Сомте, Cours, vol. 6, pp. 228-229, nota 1. 
relação à astronomia, a metalurgia em relação à química, ou a medicina em relação à biologia. Esta relatividade essencial e subordinação ao espírito de conjunto eis o primeiro carácter de positividade em política; porém, como ciência de aplicação, a política tornar-se-á de mais em mais positiva, quando, destinada a ser um meio de coordenação de forças sociais, realizar a conformação dos actos com os princípios» (1).

O ideologismo cientista, ao colocar a filosofia da história como corolário de uma análise científica da sociedade, aparecia assim com uma forte capacidade de convencimento, já que as suas propostas estariam revestidas de uma neutralidade e objectividade que se adequavam optimamente à política de conciliação de classes propugnada pelo republicanismo. A ciência justificava a possível unanimidade de posições. Por outro lado, esta crença, diga-se, possibilitava apresentar a República como um fenómeno futuro inevitável e permitia ainda reforçar a crítica contra as pretensões socialistas de sobrevalorização da questão económica e, ao mesmo tempo, oferecer um modelo de organização político-administrativa que se coadunava com as aspirações descentralistas da pequena burguesia de então.

A questão económica e a questão politica

Um dos campos em que os positivistas mais se empenharam em demonstrar o estatuto científico da política republicana foi, sem dúvida, o concernente à questão social. De facto, a querela a propósito da questão económica e da questão política foi a pedra de toque que delimitou os movimentos políticos a partir da segunda metade do século XIX. O problema era simples, e José FALCÃo, aquando da Comuna, caracterizou-o lapidarmente: «O que é o problema político? Definir a essência e fins do governo e, como corolário, determinar o mais perfeito e justo sistema de relações entre governantes e governados. Por outras palavras, buscar a melhor forma de governo»(2). E a questão económica?

(1) Teófilo Braga, Systema de Sociologia, pp. VII-VIII. Veja-se também TeIXeIra Bastos art. cit., pp. 73-74, e As Revoluções Sociais nos seculos I e XIX da Era Vulgar, in «Era Nova», pp. 63-64.

(2) José Falcão, A Comuna de Paris e o Governo de Versailles, 2. ${ }^{\mathrm{a}}$ ed., Coimbra, 1871 , p. 4. 
Seria considerar «....o problema político como mera consequência do problema económico; isto é, [entender] que a humanidade [com excepção de alguns parasitas improdutivos] só alcançará a felicidade quando a produção, repartição e consumo dos produtos do trabalho estiverem organizados de modo que o produto do trabalho pertença exclusivamente aos que trabalham, como é justo, e não a uma minoria exploradora, parasita e despótica» (1).

É certo que, nos inícios da década de setenta, muitos republicanos, incluindo o próprio JosÉ FALCÃo, apesar de positivista, ainda se inclinavam para a aceitação da importância e prioridade da questão económica sobre a questão do regime (2). No entanto, o aprofundamento do significado último das implicações do socialismo e da Comuna levou-os a abandonar, gradualmente, as suas quimeras socializantes e a colocar-se ao lado dos «políticos». Ora, em tal horizonte polémico, havia que dar uma perspectivação "científica» a esta opção republicana. Também aqui os positivistas se esforçaram por demonstrar a cientificidade dessa prioridade e o carácter subjectivo e metafísico das propostas socialistas.

Se pensamos bem, não foi outra a intenção de Té́fIlo ao editar a sua Historia das Ideias Republicanas em Portugal (1880). De facto, para além das tentativas de filiar o republicanismo na melhor tradição progressista e liberal, a obra visava ainda atacar as teses socialistas, sustentadas principalmente por ANTERo de Quental e Oliveira Martins, e, simultaneamente, justificar a posição dos republicanos no respeitante às questões político-económicas fundamentais, a saber: o Estado, a luta de classes e a propriedade privada.

Para TEÓFILo, a solução da questão económica e da situação das classes laboriosas nada tinha a «...ver com os remédios propostos pelas teorias metafísicas de Fourrier ou Saint-Simon, Considérant, Proudhon, Luis Blanc, Lassalle, Belitz ou Karl Marx, da mesma forma que os fenómenos cerebrais nada têm que ver com as explicações dos antigos psicologistas e ideólogos» (3). Para o nosso positivista republicano, a questão social devia ser analisada à luz da sociologia que apontava para a coexistência entre a ordem e o progresso, pois «por esta

(1) Idem, p. 9.

(2) Sobre este assunto, veja-se o nosso estudo José Falcão, um Lente Republicano, Coimbra, sep. da revista «Biblos», vol. 52, 1976, pp. 277-291.

(3) Té́filo Braga, Historia das Ideias Republicanas em Portugal, p. 294. 
concepção se eliminaram os preconceitos providenciais e se apreendem aqueles factos de natureza estáticos, tais como a tradição secular, a sobrevivência do costume, a recorrência às aptidões étnicas primitivas, e a orientação particular da vida histórica. Porém, quando reduzimos os fenómenos sociais a forças, estas forças não têm a simplicidade da ordem mecânica, têm a complicação crescente de forças cósmico-biológicas, de automatismos individuais e de reacções extra-motrizes, e é com esta íntima solidariedade que entram na dinâmica social e, por isso, só podem ser expressas de uma maneira geral pela designação peculiar de Factores» (1).

O evolucionismo ou progressismo assumia, assim, uma conotação política bem precisa. Como vimos, o motor da sociedade encontrava-se na evolução espontânea do espírito. Por isso, segundo TeófILo, embora houvesse inter-conexão entre os factores, os movimentos sociais mais não eram do que a resultante «....de um conjunto de factores intelectuais, morais e económicos. Augusto Comte restabeleceu a relação nesta hierarquia do progresso; como as noções mentais são o estímulo natural dos actos de vontade, dirigindo mesmo aqueles provocados pela emotividade, a actividade intelectual é a origem donde procede o desenvolvimento moral bem como destes dois factores resulta o desenvolvimento económico» (2).

Como surge e qual a posição do problema do regime político nesta hierarquia? «O governo - escreve TeófILO - é o agente coordenador de todo o funcionalismo social; desde que ele não realiza esse fim é uma anarquia sistemática em proveito de alguns» (3).

Segundo esta filosofia da história, seria a República a forma política exigida pela natureza da sociedade e a única capaz de proceder «cientificamente» à regeneração intelectual, moral e económica da nação portuguesa. Deste modo, o projecto socialista, centrado na apologia proudhoniana do abstencionismo político, tinha-se transformado, aos olhos dos republicanos, em obstáculo na luta contra a monarquia. Por isso, Teófilo advertia que «a abstenção política da grande colectividade do povo traz a perpetuidade desta anarquia, e pela indiferença colabora na dissolução. As emoções socialistas atrasam a reor-

(1) Idem, pp. 297-298.

(2) Idem, pp. 298-299.

(3) Idem, p. 314. 
ganização política deste país; estudando as bases positivas dos problemas do Socialismo, chegamos à conclusão de que aí se refugiam os metafísicos revolucionários que embaraçam a sua evolução considerando a República como uma forma política dos conservadores burgueses» (1).

A tentativa de fundamentação da prioridade da questão política sobre a questão económica assumiu uma mais clara sistematização no pensamento de Manuel Emídio Garcia. Aqui, a querela entre republicanos e socialistas, isto é, a luta entre classes e fracções de classe reflecte-se ao nível da teoria sociológica e, mais concretamente, ao nível da problemática ligada à divisão interna da Sociologia (2).

A argumentação do lente de Direito era linear. Se, como tinham sustentado Comte, Littré, Spencer, Worms, Letourneau, Guarin DE VITRY, ROBERTY, e outros, a sociedade era um organismo constituído por órgãos e respectivas funções, possuindo cada um a sua autonomia integrada na totalidade social, haveria tão-só que sistematizar essa funcionalidade e encontrar as leis particulares respeitantes a cada função. Assim, Manuel Emídio Garcia, recorrendo directamente aos ensinamentos de SPENCER e VITRY e servindo-se do princípio biologista - aplicação da «doutrina geral da biologia ao organismo sociedade» defendia que esta, para sobreviver e evoluir em face dos condicionalismos internos e cosmológicos, carecia de condições de formação, constituição e renovação, vitalidade, conservação, aperfeiçoamento, garantia. Como a cada condição corresponderia um conjunto de fenómenos passiveis de observação, comparação e filiação, a sociologia não seria mais do que a "ciência das condições de existência da sociedade», isto é, uma ciência geral que englobaria, de uma forma sistemática e hierarquizada, tantas ciências sociais particulares quantas as funções específicas do organismo social. Assim, aplicando as leis da taxinomia comteana, MANuel Emídio Garcia dividia a sociologia nas seguintes ciências: Política, Economia, Administração, Moral, Direito (3).

(1) Idem, p. 315. Veja-se também pp. 173-174.

(2) A questão da Divisão Interna da Sociologia atravessou de tal modo a problemática sociológica em Portugal durante as últimas décadas do século XIX que, em 1903, a revista lisboeta $O$ Mundo Legal e Judiciário ainda falava das divisões de Comte, Spencer, Greef, Garcia, Afonso Costa, Abúndio da Silva, etc. Veja-se O Mundo Legal e Judiciário, n. ${ }^{\circ}$ 13, XVII ano, 10-IV-1903, p. 204.

(3) Veja-se Manuel Emído Garcia, Divisão Interna da Sociologia, in «O Instituto", vol. 30, Junho-Julho, 1882-3, pp. 8-12. 
Não cabe no âmbito deste estudo analisar em pormenor a sociologia garciana. No entanto, convém desde já assinalar dois aspectos de fundamental importância para a compreensão das relações entre o positivismo e o republicanismo. Em primeiro lugar, no ideário de GARCIA, surgia devidamente dimensionado o ideologismo cientista de que os positivistas tentaram revestir as propostas republicanas. Isto é, a política não era somente uma ciência de aplicação, como queria Té́fILO, mas possuía igualmente um estatuto teórico que lhe era conferido pela especificidade do seu objecto: os fenómenos de formação, constituição e renovação. Em segundo lugar, dado que tais fenómenos se hierarquizavam segundo uma ordem de generalidade decrescente e complexidade crescente e na medida em que os fenómenos de formação, constituição e renovação seriam os menos complexos e os mais gerais, a Política ocupava a posição mais importante no conjunto das ciências sociais e respectivos fenómenos.

Se esta classificação pode parecer ingénua e destituída de qualquer valor científico, o mesmo não se pode sustentar em relação às conotações político-ideológicas que dela se podem extrair. $\mathrm{Na}$ verdade, a taxinomia apresentada por MANUEL EmíDIO GaRCIA insere-se, em última análise, na tentativa de se justificar cientificamente a opção fundamental do republicanismo e subalternizar as interpretações socialistas da sociedade. Assim, e de um modo transparente, o lente republicano explicitava as razões da prioridade dos fenómenos políticos em relação aos económicos (condições de vitalidade). «Parece à primeira vista - escrevia - que deviam ser colocadas em primeiro lugar as condições de vitalidade. Como é que o organismo se há-de formar, constituir e renovar sem condições de vitalidade? A dificuldade desaparece logo que atendamos a que, só depois de estar formado e constituído o organismo, poderemos determinar as suas condições de vitalidade; estas variam com aquelas; da maior ou menor constituição depende o maior ou menor grau de vitalidade; isto que se observa nos organismos individuais, realiza-se também com as sociedades; não ofendemos, pois, a ordem, colocando em primeiro lugar as condições de formação e constituição» (1).

(1) Manuel Emídio Garcia, Sciencia Politica e Direito Politico, Coimbra, Typ de Luiz Cardoso, 1893, p. 30. 


\section{Classes sociais e propriedade privada}

Esta contestação da prioridade dos factos económicos na deter minação das leis sociais tinha a sua outra face na questão da propriedade privada dos meios de produção e na consequente estruturação classista da sociedade. É certo que o comtismo não perfilhou a tese liberal pura sobre a propriedade, não aceitando nem a sua dedução jusnaturalista, nem a sua definição jusromanista. Para CoMTE, a propriedade era vista como necessidade de continuação histórica dos organismos individuais ou colectivos e a sua missão estava na realização de uma função sobredeterminada pelo consensus social (1). Deste modo, repudiava a tese clássica do jus utendi, fruendi et abutendi, consignada modernamente quer no Código Napoleónico, quer ainda em escritores liberais como BASTIAT e ThIERs (2).

Evidentemente que, se o positivismo atacava as concepções liberais extremas, fazia-o, contudo, em nome dos interesses capitalistas. Por isso, como vimos, contestavam igualmente as teses colectivistas que, a seus olhos, mais não eram do que reivindicações escravas do criticismo metafísico.

Os positivistas portugueses situaram-se na linha clássica do pensamento de Cомте, ainda que interpretando-o em sentido pequeno-burguês (3). A propriedade privada surgia-lhes como um produto

(1) Para CомтE, a solução do problema da propriedade não estava nem na sua contestação, nem na busca de reformas económicas. Como idealista: «....les principaux remèdes sont ici nécessairement du ressort direct des opinions et des moeurs, sans que les règlements politiques proprement dits y soient susceptibles d'aucune efficacité vraiment fondamentale; puisque tout se réduit surtout aux préjugés et aux usages publics qui, d'après une sage appréciation philosophique de l'ensemble du sujet, doivent habituellement diriger, dans l'intérêt social, l'exercice effectif de la propriété, en quelques mains qu'elle réside» (А. CомтE, Cours, vol. 4, p. 118; veja-se também p. 201). Sobre a acumulação da riqueza como elemento material de continuidade histórica, veja-se Système, t. II, pp. 154-156.

(2) Portalis, um dos legisladores do Cógido de Napoleão escrevia: «existem proprietários desde que existem homens.... em todos os tempos e lugares». O princípio da propriedade não resultava da convenção mas da «própria constituição do nosso ser.... Ao nascer o homem traz apenas necessidades.... Ele tem, portanto, um direito natural às coisas necessárias à sua subsistência e sustento» (cit. in JEAN-Philippe Lévy, História da Propriedade, Lisboa, Ed. Estampa, 1973, p. 113).

(3) «Os objectos de transformação pertencem ao meio cósmico, e como não se pode abstrair no movimento social do tempo percorrido, ou condições históricas, 
histórico-natural e verificavam que a sua forma moderna estava na base da crise social que atravessava o século XIX (1). Sem aceitarem as remédios, concordavam com as análises de SAINT-Simon, Fourier, Carey, Proudhon e outros (2). Reconheciam, portanto, que o desenvolvimento do capitalismo levava a «....concluir que o futuro pertence aos grandes capitais» $\left({ }^{3}\right)$, e que o proletariado, pelo simples facto de só ser proprietário da sua força de trabalho, estava sujeito a uma exploração desenfreada.

No entanto, ao contrário de Proudhon, para eles, a solução não estava no regresso a fo:mas parcelares ou individuais de exploração, nem, como queriam os socialistas revolucionários, na socialização dos meios de produção através do estado $\left({ }^{4}\right)$. Pelo contrário, a "guerra à propriedade, ou abolição da propriedade individual, dissociação do capital, resistência pela abstenção dos interesses políticos - escrevia TEófILo contra os socialistas utópicos - são males tão profundos como aqueles produzidos pelas devastações dos monarcas» (5). Haveria, assim, que salvar a propriedade privada e, ao mesmo tempo, atenuar e harmonizar as contradições sociais. $\mathrm{O}$ único meio que se adequava à estrutura orgânica da sociedade e à consequente reciprocidade ou cooperação das funções e factores seria a Associação ou a Cooperação. Criticando o valor da própria palavra Socialismo, TEófıLo chegou a sustentar que só o associacionismo possuía um estatuto científico (6).

é por isso que existem esses objectos em poder de quem deles se apoderava primeiro e os conservou» (Té́fIlo Braga, Historia das Ideias Republicanas em Portugal, p. 307). Justificava-se, assim, a propriedade através do direito de ocupação.

(1) Julgamos que os ensinamentos de LAVELLEY sobre a dimensão histórica da propriedade foram perfilhados por Té́filo Braga (veja-se Idem, p. 293). Por sua vez, Manuel. Emídio Garcia, inspirando-se nos dados etnológicos de Spencer e de Letourneau, aceitava a existência de um comunismo primitivo (veja-se MANUEL Emídio Garcia, Ciência Politica e Direito Publico, Coimbra, Lithographia Marco da Feira, pp. 216-218).

(2) Veja-se Teófilo Braga, Systema de Sociologia, pp. 329-330.

(3) Idem, ibidem.

(4) Idem, p. 330.

(5) Teófilo Braga, Historia das Ideias Republicanas em Portugal, p. 311. Veja-se também Carrilho Videira e Teixeira Bastos, Cathecismo Republicano para uso do povo, Lisboa, Nova Livraria Internacional, 1880, pp. 39-40.

(6) Idem, pp. 313-314. 
O associacionismo aparecia como uma panaceia capaz de anular o egoísmo tradicional das classes dominantes e, ao mesmo tempo, reforçar a força social do proletariado. No entanto, perante esta nomenclatura, devemos indagar qual a forma concreta como anteviam a reorganização da sociedade baseada neste princípio (1). Parece-nos que ela radicava numa intenção indesmentível: conciliar o capital com o trabalho. Quanto à via dessa concretização, a ambiguidade terminológica poder-nos-ia levar a crer que estamos perante uma doutrina que sintonizava com o modelo cooperativista. Mas, se por cooperativismo entendermos uma forma de propriedade que conduz à transição do capitalismo para o socialismo, esse não foi o ideário dos nossos positivistas e, sobretudo, do seu mais importante ideólogo político, Teófilo Braga. Ao contrário, os termos associação ou cooperação surgem impregnados de biologismo e queriam dizer tão só que, devido à lei da divisão do trabalho e à possibilidade de ilustração do proletariado, todas as classes e todas as funções seriam igualmente necessárias (2). Por conseguinte, em vez de as classes lutarem entre si, como queriam os socialismos revolucionários - luta essa que resultava de uma política empírica, desconhecedora das leis sociais -, dever-se-ia reconhecer essa reciprocidade orgânica e elevá-la ao nível do sentimento e da ética social (3). Só assim se poderia liquidar o egoísmo dos possidentes e o revolucionarismo dos dominados.

Quase se tornava desnecessário sublinhar que, partindo desta ideia de propriedade, os nossos positivistas não ultrapassaram o conceito burguês de igualdade formal e que, portanto, a sociedade lhes aparecia como um todo estruturado não só por órgãos, mas também por classes

(1) Sobre a questão das relações entre classes, veja-se Teófilo BRAGA, op. cit., pp. 261-315.

(2) Veja-se Teófilo Braga, Systema de Sociologia, p. 330.

(3) Quer isto dizer que, tal como o comtismo em geral, também o pensamento dos nossos positivistas estava voltado para a tentativa de integrar o proletariado no sistema capitalista. Num período posterior àquele que estamos a estudar, mas de uma forma altamente esclarecedora, TEÓFILo escrevia: "A revolução moderna assenta sobre dois trabalhos fundamentais: reorganizar o Poder espiritual, que pertenceu às religiões, substituindo esse conjunto de ficções por verdades demonstradas pelas Ciências, formando uma nova síntese do universo, e - incorporar o Proletariado na sociedade moderna, pela preponderância do trabalho pacífico e dos deveres sobre os direitos» (Teófilo Braga, Soluções Positivas de Política Portugueza, Porto, Livraria Chardron, 1912, p. 162). 
determinadas. A sistematização teofiliana parece-nos sumamente ilustrativa da hierarquização social positivista.

Partindo da mútua dependência entre as classes, Teófilo concluía que existia uma hierarquia recíproca entre elas ( $\left.{ }^{1}\right)$. $\mathrm{Na}$ base da escala encontrava-se o operariado que, pelo seu número e capacidade transformadora, criava um valor correspondente à energia gasta no processo produtivo, em função da qual recebia um salário correspondente. Mas, como a matéria bruta pertencia ao meio cósmico e tinha sido socialmente apropriada em dado momento histórico, a produção exigia a propriedade privada e, por conseguinte, o capitalista.

Mas, para além destas duas classes fundamentais, o funcionamento da sociedade necessitava do trabalho de uma outra, o comerciante, pois havia que colocar o produto à mercê de quem dele necessitava. E se o operário dependia do capitalista, este acabava por depender do comerciante.

Em seguida, TeófIlo, raciocinando com base na ideia de valor, acabava por deduzir a necessidade do banqueiro. Com efeito, se a moeda condensava ou simbolizava os valores económicos e, ao mesmo tempo, era um objecto de troca, a actividade bancária impunha-se como uma exigência do próprio progresso económico.

Sonhando com a harmonização de todos estes interesses, o republicanismo apontava para uma política inter-classista. Por isso, nem colocou o acento na força revolucionária dos trabalhadores, como queriam os socialistas, nem reivindicou o poder temporal para o controlo directo dos banqueiros, como propôs A. CoмTE. É neste campo que a leitura do positivismo feita à luz dos interesses político-sociais das classes médias surge com toda a nitidez. Os banqueiros, embora fossem uma classe necessária, possuiam «....uma inferioridade mental» e, pelo «seu egoísmo, proveniente da boçalidade», afastavam «para muito longe a previsão de Augusto Comte, que considerava o banqueiro como uma das formas do poder temporal das sociedades modernas» (2). Por conseguinte, esta revisão do ideário comteano revela-nos a rejeição de um poder politico controlado pela alta burguesia e é reflexo directo da luta das classes médias portuguesas contra os grupos sociais que controlavam a monarquia constitucional.

(1) Idem, pp. 306-308.

(2) Idem, p. 308 . Veja-se A. Coмte, Système, t. IV, pp. 349 e ss. e 448 e ss. 
Com maior ou menor fidelidade ao pensamento de COMTE, o certo é que os nossos positivistas tudo fizeram para defender os valores essenciais da sociedade capitalista, enquadrando-os num regime republicano que desse a hegemonia política, económica e ideológica às camadas burguesas não pertencentes nem à banca, nem ao grande comércio, nem ao clero, nem aos grandes proprieários rurais. Daí que procurassem aglutinar todas as restantes classes e grupos sociais à volta de um programa democrático, formal e evolucionista, cujos interesses seriam realizados através de uma forma de estado centralista, federal e republicano.

\section{POSITIVISMO E DESCENTRALISMO}

\section{A questão municipalista e iberista}

Reivindicando a herança dos princípios políticos vintistas e incorporando o essencial das posições doutrinais da corrente democrática, os nossos republicanos tinham de ser particularmente sensíveis a uma forma de estado descentralista e federalista. Por isso, estas duas questões foram das que mais entusiasmaram as primeiras gerações republicanas.

$\mathrm{Na}$ verdade, o municipalismo já constituía uma reivindicação típica do monarquismo liberal. Compreende-se. Do ponto de vista ideológico, tratava-se então de fundamentar uma nova teoria da legitimação do poder e um novo modelo de organização político-administrativa que se contrapusesse à estrutura e à doutrina do estado absolutista. Consequentemente, a história foi lida à luz destas preocupações è as liberdades comunais das monarquias medievais apareciam como a essência da organização popular, adulterada pela monopolização régia dos séculos XVI-XVIII (1). O município apareceria, portanto, como a pre-

(1) Na linha descentralista de Herculano, Manuel Emídio Garcia apontava que o município teria aparecido «no berço da nacionalidade rudimentarmente constituído, perfeita ou imperfeitamente organizado, segundo a evolução histórica e o menor grau de independência de que nesses tempos gozavam as diferentes associações locais" (Manuel Emídio Garcia, Descentralização e Preconceitos, in "Correspondência de Coimbra", n. ${ }^{\circ} 30$, I ano, 21-VI-1872, p. 1, col. 1). 
figuração do modelo de estado que iria trazer o self-government e evitar a hegemonização dos interesses particulares da aristocracia. Dito de outro modo, o estado descentralista permitiria uma maior realização do poder político das classes médias e evitaria o controlo macrocéfalo que as altas camadas da nobreza e da burguesia conseguiram através do modelo centralista (1).

Diga-se que não foi outra a preocupação de Herculano e, até certo ponto, dos legisladores da Constituição de 1822, das medidas descentralistas contidas na legislação de Mouzinho da Silveira e no Código Administrativo de Passos Manuel (1836). Só que o domínio crescente dos sectores mais conservadores do liberalismo monárquico levou a uma gradual abdicação desta intenção descentralizadora. Assim, os municípios que, em 1845 , atingiam o número de 802 , foram reduzidos a 351 pelo Código Administrativo de 1846 (2). Por tudo isto, a luta a favor da realização integral dos princípios do liberalismo passou a ser indissociável da reivindicação de um municipalismo adequado à natureza histórica, política e geográfica das diversas regiões do país.

Entretanto, algumas modificações se deram no quadro ideológico do Portugal dos meados de oitocentos com reflexos na problematização descentralista. Referiamo-nos à emergência de um ideário que, sem estar em ruptura com os princípios do liberalismo, o enquadrava numa óptica socializante e republicana. Na verdade, as teorizações de FÉLIX Henriques Nogueira, Lopes Mendonça e de toda a geração de 50, ao sensibilizarem-se com os acontecimentos políticos franceses de 1848 e ao darem guarida às propostas do socialismo utópico que então medraram, vieram republicanizar a questão municipalista, (3) interligando-a

(1) «A centralização política gera necessariamente a centralização administrativa, económica, científica, moral, todas as centralizações possíveis e imagináveis» (Manuel Emídio Garcia, Reformas - A Política e a Administração, in "Correspondência de Coimbra", n. ${ }^{\circ}$ 6, I ano, 4-II-1872, p. 1, col. 3).

(2) Sobre o decréscimo das regiões municipalistas e a gradual perda da sua autonomia, leia-se todo o artigo de Manuel Emídio Garcia atrás citado.

(3) Veja-se J. Félix Henriques Nogueira, Estudos sobre a Reforma em Portugal, Coimbra, Imprensa da Universidade, 1923, pp. 169 e ss. e $O$ Municipio no século $X I X$, Lisboa, Ed. Francisco Luiz Gonçalves, s. d.. Sobre o pensamento de LOPES MENDONÇA e a sua inserção na problemática da sua geração, leia-se: MARIA Manuela Bastos Tavares Ribeiro, Lopes de Mendonça - A Obra e o Pensamento, Coimbra, 1974, pp. 381-494 e 629-782. 
com uma outra, sua consequência lógica ao nível da política externa ${ }^{(1)}$ : a questão federal (2).

Com efeito, no campo das doutrinas democráticas e socializantes desse período, as expectativas internacionalistas começaram a ganhar um novo impulso teórico. É facto que não constituíam uma novidade total, dado que se inseriam no horizonte ecuménico da filosofia política iluminista. Só que o empolamento dessa problemática constituía o reflexo da mundialização crescente das relações capitalistas e a sua conotação política inseria-se mais directamente nas ideologias das classes que as suportavam. Consequentemente, parece-nos que a macrocefalização e a destruição da autonomia política, cultural e económica das regiões, levada a cabo pela hegemonização do poder da alta burguesia, conduziu a que os movimentos das classes médias, e depois os movimentos operários organizados, reivindicassem um estado descentralizado, a nível interno, e estivessem conscientes de que, no campo externo, só uma cooperação federal entre estados poderia fazer reviver, com autonomia, as realidades nacionais e evitar a sua subordinação aos grandes impérios capitalistas-colonialistas.

O caso português - e ibérico - é sumamente ilustrativo do que afirmámos. Constituindo a Península, depois do período áureo das Descobertas, duas nacionalidades decadentes e internacionalmente subalternizadas e sendo governadas por monarquias conservadoras e centralistas, duas correntes político-administrativas se delimitaram com perfeita nitidez a partir dos meados do séc. XIX: uma, de cariz monarquista, via na união ibérica a única possibilidade de se reconstruir a grandeza perdida e, no fundo, a única saída para a sobrevivência da

(1) Inter-relacionando os níveis interno e externo implicados na opção federalista, François Pérroux escreveu: "Les fédérations entre États supposent que chaque État a, lui-même, une forme fédérative. Puisque la fédération est la forme politique de l'humanité, elle est une recette applicable aux individus comme aux États, et elle renferme la véritable garantie de l'excellence des rapports entre particuliers" (FraNçors Pérroux, Ambiguité du Fédéralisme, in «Nations ou Fédéralisme», Paris, Plon, 1946, p. 92).

(2) Comparando a obra de Henriques Nogueira com a de Alexandre Herculano, Teófilo Braga não deixou de assinalar os limites do descentralismo do autor da História de Portugal, que não soube estendê-lo à dimensão federalista. Veja-se, Teófilo Braga, Soluções Positivas de Politica Portuguesa, pp. 41 e ss.; veja-se também Té́filo Braga, Henriques Nogueira, in «Era Nova», Lisboa, Escriptorio da «Era Nova», 1881, pp. 289-292. 
monarquia; a outra, relacionando os problemas administrativos com os políticos, via no regime republicano, descentralista e federalista, o único caminho conducente a uma verdadeira revivescência das nacionalidades ibéricas ( $\left.{ }^{1}\right)$.

De facto, embora o problema não fosse inteiramente novo, foi com a publicação da obra de D. Sinibaldo DE MAS, La Iberia (1852) (2), e com o prefácio de LATINo CoElHo - ainda monárquico - , que a polémica se inaugurou, vindo a atingir uma intensidade tal que, nas décadas seguintes, vieram a lume cerca de duas centenas de obras sobre o assunto ( ${ }^{3}$ ). Deste modo, a importância que o problema assumiu nos meios intelectuais portugueses e espanhóis espelha a sua acuidade no conjunto das medidas propugnadas para se vencer a crise resultante da gradual hegemonização do modo de produção capitalista na Península Ibérica. E, se os unionistas, sobretudo no período de crise - ex.: 1868 -, viam na fusão das coroas a única possibilidade para o reforço interno e externo $\left(^{4}\right)$ da monarquia, os federalistas sustentavam que a república

(1) Não passaram despercebidas à perspicácia historiográfica de OLIVEIRA MARTINS as razões político-sociais determinantes do surto iberista no século XIX. Por isso, assinalou que, "desde que as revoluções peninsulares ponham em risco a estabilidade das instituições e as crises sociais agitem as populações, desde que, ao mesmo tempo, não haja na Europa interesse bastante forte para determinar intervenções, o Iberismo tem de ser o pano de fundo político de todos os movimentos, quer na Espanha, quer já agora em Portugal» (Oliveira Martins, Dispersos, t. II, Lisboa, Oficinas da Biblioteca Nacional, 1924, pp. 260-261). A ligação entre a questão federal e as expectativas regeneradoras foi por ele antevista nestes termos: «com este novo espírito [regenerador] português tinha-se também insinuado em Portugal um corpo de sentimentos modernos, ainda mal definido em ideias, misto de socialismo humanitário e republicanismo cosmopolita, federalista» (OLIveira Martins, Portugal Contemporâneo, vol. 3, Lisboa, Guimarães Editores, 1953, p. 249).

(2) D. Sinibaldo de MAS, A Iberia, 2. a ed., Lisboa, Typ. Universal, 1853.

(3) Entre 1852 e 1881, saíram em Portugal pelo menos 161 obras sobre a questão ibérica. Cfr. INOCÊNCIO, Diccionario, t. X, pp. 35-48.

(4) A preocupação de vencer a subalternidade de Portugal e Espanha face às potências da época é uma constante tanto das teses unionistas como das federalistas. Assim, para D. Sinibaldo de MAS, Santarém devia ser a nova capital do reino ibérico, precisamente porque «seria a cidade de onde o ferro-carril há-de atravessar o Tejo. Situada ali, a corte ibérica estaria longe da influência francesa e a coberto de um golpe de mão da esquadra inglesa» (D. Sinibaldo de MAS, op. cit., p. 171). Por sua vez, LATino CoElHo acentuava esta ideia de subalternização imperialista, escrevendo: «Se Portugal, como se depreende dos deploráveis exemplos que 
municipalista e federalista seria a única forma de estado consentânea com os princípios do liberalismo, capaz de regenerar as sociedades ibéricas e integrá-las num contexto de equilíbrio europeu (1).

Ora, se o federalismo estava na ordem das exigências da luta contra a monarquia, lutar por ele tornou-se sinónimo de pugnar pela instauração de uma comunidade republicana de povos. Assim, sintomaticamente, ANTÓNIO ENES, ainda republicano, podia escrever em 1870: «As monarquias são unitárias. Por isso, em Portugal, são patriotas os republicanos, e amam a independência nacional os que desejam ver estabelecido na Europa o sistema federal» (2).

Não se pense, contudo, que existia uma plena unanimidade no seio do movimento republicano em relação às teses descentralistas e federalistas, ou que estas lhes eram exclusivas. Pelo contrário, também a corrente socialista as reivindicava, chegando mesmo ao exagero anti-nacionalista do jovem ANTERo (3).

Por outro lado, dentro do republicanismo, pelo menos nos inícios da década de setenta, a facção unitarista - Latino CoElho, Elias Garcia, Oliveira Marreca - opunha algumas reservas à tendência anti-centralista. Só com a aç̧ão doutrinal de dirigentes como EMíDIo Garcia, Teófilo, Teixeira Bastos, Carrilho Videira, Magalhães Lima e outros, se foi esbatendo esta oposição, vindo-se a alcançar um consenso alicerçado na demonstração e no convencimento de que

acabamos de citar, não pode hoje aspirar à prosperidade pública, a sua fraqueza não consente que seja a sua bandeira respeitada no exterior. Para se manter no meio da Europa, precisa curvar-se à Inglaterra, que sobre ele exerce um verdadeiro protectorado, encoberto nas aparências de uma aliança amigável e generosa» (LATINo Coelho, Prólogo, in D. Sinibaldo Mas, op. cit., p. XI). No campo federalista, o anti-imperialismo era igualmente a pedra de toque do ideal cosmopolita e, por outro lado, via-se nele a única forma capaz de regenerar o país e reconstruir a grandeza colonial perdida.

(1) O ideal de paz perpétua surge interligado à capacidade harmónica que teria uma sociedade económica federalista. Veja-se António Enes, A Guerra e a Democracia, pp. 12 e ss., os artigos de Manuel Emídio Garcia, $A$ Guerra e a Diplomacia, espalhados pela Correspondência de Coimbra, e Teórilo Braga, Systema de Sociologia, pp. 276-277, 313-314, 318-320, 329-330.

(2) António Enes, A Guerra e a Democracia, Lisboa, Imprensa de J. G. de Sousa Nunes, 1870, p. 23.

(3) Com efeito, no seu opúsculo datado de 1868, Portugal perante a Revolução de Espanha, ANTERo defende a tese da supressão das nacionalidades. 
o descentralismo não destruiria a unidade nacional, nem o confederalismo internacionalista de povos «mataria» a realidade orgânica e espiritual das nacionalidades.

\section{$O$ indivíduo e a sociedade}

De facto, foi decisiva a acção dos pensadores positivistas na fundamentação do descentralismo e do federalismo e na demonstração da possibilidade de uma conciliação com o republicanismo unitarista e democrático. Mas, também aqui, a realização desta tarefa impunha uma fidelidade não ortodoxa aos ensinamentos de ComTE, já que, como sabemos, se o seu organicismo admitia a autonomia regional dos órgãos intermédios da sociedade, não deixava de apontar, no entanto, para um estatismo exagerado. Por outro lado, o anti-individualismo da doutrina não permitia colocar o descentralismo ao serviço do ideário liberal que o republicanismo defendia.

Assim se compreende que os nossos positivistas tenham rejeitado o princípio comteano da hierarquia social, no qual a família aparecia não como célula, mas como o primordial tecido da sociedade, como o elemento base. Era facto que, como assinalava TeIXEIRA BASTos, a família (1) era «....incontestavelmente e com razão um dos fenómenos

(1) De qualquer modo, a valorização do estatuto do indivíduo na escala orgânico-social não implicou uma desvalorização da importância do papel da família no funcionamento da totalidade orgânica. Como em Augusto ComTE, a sua função reprodutora da espécie e de elo de transmissão cultural entre o passado e o futuro foi devidamente sublinhada. Por outro lado, também a sua importância como meio de aperfeiçoamento social (a relação sexual duradoura estaria internamente ligada ao desenvolvimento da ética altruísta) teve acolhimento nos nossos positivistas. No entanto, e contrariamente àquilo que o comtismo ortodoxo sustentava, a posição da família na sociedade científico-industrial foi equacionada à luz da óptica laicista típica do positivismo heterodoxo mais radical. Assim, ainda que aceitassem a desigualdade física e intelectual da mulher em relação ao homem e tirassem desse facto ilações de carácter social, o certo é que reconheciam a sua igualdade formal e, consequentemente, os direitos políticos e o direito ao divórcio. Elucidativamente, no livro mais esclarecedor da posição dos positivistas portugueses face a este problema, TeIXeIRA Bastos escrevia: "O homem e a mulher são igualmente livres e responsáveis pelos seus actos perante a sociedade; devem ter idênticos direitos, ou melhor os deveres de cada indivíduo, masculino ou feminino, para com os seus semelhantes derivam da equivalência fundamental de todos os seres que constituem o 
que mais têm atraído os que se dedicam ao estudo da sociologia, porque a família está para a socicdade como a célula está para o organismo» (1). Mas, a necessidade liberalista de fazer inserir o indivíduo na base da totalidade social levou a defini-lo, ainda que atropelando os princípios biologistas, como a resultante do conjunto de células, sendo a comuna e a nação órgãos resultantes da reunião de famílias (2).

Independentemente da inversão da ordem biológica - o indivíduo nunca poderia ser o produto de uma reunião de células-famílias -, o certo é que esta nota individualista encontra-se nos restantes positivistas, para os quais o indivíduo, enquanto ser mais complexo da escala social, ocupava a posição dominante. Por sua vez, para que este individualismo se demarcasse das correntes metafísicas, a sua inserção no conjunto social não era mediada, como defendiam os contratualistas, por qualquer acto de vontade, mas surgia como a resultante necessária de um consenso social que se graduava segundo a seguinte hierarquia: indivíduo, família, paróquia, município, província, nação, federação de povos, humanidade (3).

género humano. A especialidade de funções entre os sexos e mesmo entre todos os homens em nada altera a noção positiva da igualdade humana. A dignidade social, proclamada por Augusto Comte, enobrece as mais simples profissões, porque a mentalidade moderna reveste todas as actividades parciais do mesmo carácter de funções públicas. Cada qual deverá ocupar o lugar que lhe compete segundo as suas aptidões naturais, sem a intervenção injusta do acaso do nascimento ou da fortuna. Homens e mulheres, todos sem distinção, têm diante de si a grande liça aberta para os combates da existência.... Naturalmente as aptidões regulares da mulher, devidas à sua constituição fisiológica e desenvolvidasdurante a longa marcha histórica da humanidade, levá-la-ão de futuro para a vida interior do lar, de preferência a lutar com o homem no campo dos trabalhos manuais e da inteligência» (Teixeira Bastos, A Familia, Porto, Magalhães e Moniz, Editores, 1884, pp. 209-210). E sobre o divórcio escrevia: «....o divórcio, em vez de promover a destruição da família, aperfeiçoa-a, conduzindo os cônjuges a uma união mais íntima, a uma maior harmonia moral, enfim à verdadeira indissolubilidade e perpetuidade do matrimónio (Idem, p. 190).

(1) Teixeira Bastos, Origem da Familia, in «O Positivismo», n. ${ }^{\circ} 3$, I ano, Abril-Maio, 1881, p. 225. Aqui, desde logo se nota uma distância face a A. СомтE, para quem, a nível biológico, a célula não possuia qualquer espécie de realidade. Ao contrário, para ele, o elemento fundamental do organismo era o tecido.

(2) «Como do agregado de células se forma o tecido, e da junção de células o indivíduo, assim - conclui TeIXEIRA BASTOS - a reunião de famílias produz a cidade ou a comuna, e a liga de cidades ou comunas origina a nação» (Idem, ibidem).

(3) Esta questão será pormenorizadamente desenvolvida no nosso trabalho sobre MANuel Emídio Garcia. 
Ora, dado que o social só em função da coordenação das partes funcionava, cada órgão regional não só possuía uma autonomia ôntica que lhe era própria, como contribuía para o funcionamento harmónico do todo. Deste modo, o princípio da totalidade exigia que a esta ordem natural correspondesse uma organização político-administrativa adequada, a qual, como veremos, só podia ser o descentralismo interno e o federalismo a nível externo. Sendo assim, o pluralismo tinha de consistir num «....certo número de princípios sociológicos que formam um sistema político e social, tendo por base a autonomia das diversas individualidades, em que a sociedade está naturalmente dividida, autonomia que não afecta a dependência e subordinação necessárias para a existência da unidade que o estado social fatalmente exige» (1).

$\mathrm{E}$, invocando os princípios organicistas spencerianos, sustentava-se que, naquele período, não haveria «inteligência por mais culta que seja, que ouse contestar os princípios federalistas. Eles constituem a doutrina que, na ordem dos factos sociais, corresponde à doutrina da integração e diferenciação existentes, as quais compreendem todo o processo da evolução universal» (2). Deste modo, o federalismo seria «....uma confederação de órgãos relativamente perfeitissima, e digo relativamente perfeitissima porque nela se vão operando, de geração em geração, transformações tendentes a uma descentralização sucessivamente mais complexa, e a uma centralização cada vez mais simples» (3).

Por sua vez, a ordem naturalista correspondia à tendência histórica e às exigências étnicas dos povos europeus. Daí que esta leitura estática do organismo tivesse de ser acompanhada pela comprovação dinâmica, exigida pelo historicismo positivista, e isto porque, como assinalava Teófilo em 1880, «o que se dá no fenómeno biológico continua-se no facto social; a autonomia local, que as doutrinas políticas do federalismo coordenou como base consciente do estado, tem também um desenvolvimento progressivo, que os grandes publicistas da Europa alcançaram já, e que denominam por essa frase inglesa de self-government, o indivíduo subordinando-se a si próprio pelo conhecimento

(1) Horácio Ferrari, Discurso lido na sessão de abertura do Centro Republicano Federal, Coimbra, Typ. Democrática, 1879, p. 7.

(2) Idem, ibidem.

(3) Idem, ibidem. 
do lugar na colectividade. É sublime a concordância da doutrina teórica com os factos históricos» (1).

Ora, apesar de tudo, para TeófiLo, a filosofia positivista preferiria a «demonstração da verdade do Federalismo e da sua necessidade por meio de provas históricas tiradas da persistência étnica» (2). Por isso, recorrendo aos ensinamentos de Henriques Nogueira (3), PI Y Margall e Francisco Tubino (4), procurou demonstrar a necessidade do federalismo ibérico sem alienação das nacionalidades, à luz de argumentos tirados da etnia, da língua e da cultura dos povos peninsulares. Na mesma linha, mas com uma nota menos rácica, MaNUEL EmíDIo GARCIA também invocava a necessidade do descentralismo e do federalismo através de argumentos naturalistas e culturalistas, que seriam uma exigência «natural e histórica» dos povos peninsulares ${ }^{(5)}$.

A sociedade seria, assim, um todo heterogéneo, possuindo os seus organismos intermédios um estatuto próprio que, produzido natural e necessarimente, não resultava, como queria a filosofia metafísica, de um acto de vontade dos indivíduos nela incluídos. Mas a experiência paradigmática e exaltante dos federalismos existentes - Estados Unidos e Suíça $\left({ }^{6}\right)$ - colidia com este naturalismo, dado

(1) Teófilo Braga, Historia das Ideias Republicanas em Portugal, p. 331.

(2) Dito de outro modo, para o autor, a República Federalista só seria legítima, não quando resultasse de uma opção subjectivista e voluntarista, mas quando assentasse numa: «base étnica e histórica para o reconhecimento da individualidade política dos estados federados» (Idem, p. 327).

(3) Diga-se que o democratismo descentralista e federalista sensibilizou a grande maioria dos ideólogos republicanos. Assim se formou em sua honra o Club Henriques Nogueira e se lançaram dois números especiais de $A$ Era Nova dedicados ao seu ideário, nos quais colaboraram, entre outros: Teófilo Braga, Elias Garcia, latino Coelho, Manuel de Arriaga, Rodrigues de Freitas, Consiglieri Pedroso, Júlio de Matos, Alves da Veiga, Jacinto Nunes, Augusto Rocha, AlexandRe da Conceição, Manuel Emídio Garcia e Magalhães lima ( $A$ Era Nova, n. ${ }^{\circ}$ 34, II ano, 25-II-1883, e n. ${ }^{\circ} 35$, II ano, 1-III-1883).

(4) Veja-se Té́filo Braga, Las Nacionalidades-Análise do livro de Pi $y$ Margall, in «O Positivismo», n. ${ }^{\circ} 4$, I ano, Abril-Maio, 1879, pp. 300-307, e Systema de Sociologia, pp. 237-251. Sobre o federalismo de PI e a sua inserção no contexto político-social da Espanha de oitocentos, veja-se ANToni Jutglar, El Constitucionalismo Revolucionario de Pi y Margall, Madrid, Taurus Ediciones, 1970.

(5) Veja-se o nosso estudo sobre Manuel Emído Garcia.

(6) O impacto do modelo político-administrativo destes dois países foi tão grande que se encontra em toda a propaganda republicana. Por isso, a obra didáctica 
que eram indesmentíveis produtos de contratos celebrados livremente entre povos. Teria razão Proudhon que em Du Principe Fédératif o colocava como uma construção política resultante do livre-arbítrio individual? De facto, os positivistas reconheciam o problema, pois sabiam que a federação de estados tinha de ser formada por «...um acordo, não tácito e institutivo, como nas épocas atrasadas, mas claro, explícito e escrito, cuja forma é o contrato federativo» (1). Mas ainda que fosse aparentemente um acto de livre vontade, também a sua exigência seria determinada pela evolução necessária das sociedades modernas.

Apesar desta especificidade fundante, o certo é que o positivismo dava continuidade às correntes democráticas que tiveram, neste período, em Proudhon, Ahrens, Vacherot e Stuart Mill os seus principais sistematizadores. Com isso, procuravam, no fundo, dar uma nova resposta a um problema velho - a coexistência da Liberdade com a Autoridade $(2)$ - e fundamentar uma ordem liberal que transcendesse

de Teixeira Bastos e Carrilho Videira, $O$ Cathecismo Republicano, não o deixava de assinalar em termos empolados; veja-se Teixeira Bastos e Carrilho Videira, Cathecismo Republicano para uso do Povo, p. 20.

(1) Té́fllo Braga, Systema de Sociologia, p. 273. Veja-se também Telxeira Bastos e Carrilho Videira, op. cit., pp. 24-28, e Magalhães lima, $O$ Federalismo, Lisboa, Companhia Nacional Editora, 1898, p. 5. Cf. Proudhon, Du Principe Fédératif, Paris, Marcel Rivière, 1959, pp. 315-323.

(2) Já em 1872, Manuel Emído Garcia afirmava que a dicotomia entre os dois princípios é «um sofisma pueril e astucioso, mas é uma verdade; é um cálculo, mas não é um princípio científico; será uma solução prática de circunstância, de conveniência, de oportunidade, mas não é, nem pode ser a solução conscienciosa e demonstrável de um dos maiores problemas sociais - a harmonia, a identidade entre liberdade individual e autoridade colectiva» (MANUEL Emílo GARCIA, Reformas - A Política e a Administração, in "Correspondência de Coimbra", I ano, n. ${ }^{\circ} 6$, 4-II-1872, col. $3 .^{\circ}$, p. 1). Por sua vez, também para TEófilo a história da civilização consistiria «no desenvolvimento crescente das actividades individuais e na decrescente intervenção do Estado nas relações particulares; a política, como função coordenadora de todos os factos sociais, precisa de estabelecer um justo equilíbrio, uma natural ponderação entre as aspirações individuais ou a Liberdade, e as intervenções do Estado ou a Autoridade.... Os modernos publicistas partem deste ponto do desenvolvimento do indivíduo para estabelecerem a doutrina do Self-Government. Cada indivíduo, tanto mais perfeito e completo no seu desenvolvimento, tanto mais se acha emancipado da intervenção da Autoridade nos seus actos; e, se essa perfectibilidade for possível de generalizar-se, então chegaremos, como o desejava Proudhon, à eliminação total da Autoridade como desnecessária» (TEÓfIlo BRAGA, op. cit., pp. 271- 
quer os quadros concentracionários do grande capitalismo interno, quer as fronteiras do nacionalismo estreito.

Assim, quanto ao primeiro aspecto e contra o individualismo kantiano, sabiam que seria impossível realizar-se a liberdade sem a existência de um mínimo de autoridade; mas, ao contrário do que defendiam, por motivos diferentes, os absolutistas, constitucionalistas e socialistas de estado, rejeitavam a supremacia plena do princípio da Autoridade sobre o da Liberdade. Como Proudhon, embora com outros argumentos, pensavam que a natureza estrutural das sociedades, bem como a tendência histórica dominante nos povos europeus, iria impôr um estado descentralizado e federal, o único capaz de edificar uma sociedade em que ambos os princípios coexistiriam de modo a possibilitar, como queria o liberalismo consequente, a plena realização do indivíduo através do self-government.

Evidentemente que a concretização deste ideal não seria imediata, nem poderia seguir um caminho arbitrário, pois se a República era o seu corolário regimental, o concerto federativo impunha a sua instauração prévia em países de afinidades étnico-culturais. Sendo assim, numa primeira etapa, Portugal só poderia federar-se com os povos peninsulares ( ${ }^{1}$ ).

-272). Como veremos, este horizonte anarquizante manteve-se presente no espírito de muitos tribunos republicanos (António José de Almeida, Manuel de ArRiaga, por exemplo). Sendo assim, é um facto que, neste campo, os nossos republicanos se distanciaram do estatismo comteano e, invocando explicitamente os teorizadores do self-government (StUart Mill, ProudhoN), procediam a um curioso acasalamento entre a filosofia liberal e o anarquismo proudhoniano. No entanto, este aparecia reduzido a um ideal puramente político-administrativo, sendo, portanto, recuperado para um projecto político que se queria demarcar das opções socialistas. Ao contrário, o ecletismo doutrinal do republicanismo não deixava de exprimir o carácter social heterogéneo de um movimento alimentado pelas classes médias, mas que apontava também para as classes trabalhadoras. Ora, sabendo-se que a tendência dominante no movimento operário organizado foi de inspiração anarquista, pode explicar-se a persistência de tais teses na propaganda republicana, ainda que a sua concretização fosse adiada para o período posterior à queda da monarquia.

(1) «A união ibérica, como um facto histórico e progressivo, não pode ser senão uma federação. Mas, para que isto se possa efectuar organicamente, é preciso que a Espanha, atendendo aos seus elementos étnicos, realize a unificação política segundo o princípio federalista. Só assim é que na península Portugal poderá formar com os estados espanhóis uma liga ibérica, da mesma forma que estas duas nacionalidades distintas se conservarão sempre autónomas sob o regime de uma grande República Ocidental, compreendendo na sua confederação a França, a Itália, a Espanha e Por- 
Seguidamente, federar-se-ia com os restantes estados latinos, onde a França desempenharia o papel de vanguarda (1). Da confluência desta federação de famílias de povos nasceria aquilo a que Proudhon chamou Estados Unidos da Europa, micro-sociedade fundamental para a longínqua confederação de todas as nações no seio do super-organismo chamado Humanidade (2). Por isso, TeófIlo podia escrever em 1881: «A civilização Ocidental, isto é, o renascimento dos povos peninsulares, vem activar a iniciação da era pacífica, tendo passado a hegemonia para a França democrática; esse renascimento começa com as lutas da Grécia moderna para a sua independência e a sua constituição em nacionalidade livre; seguiu-se-lhe a Itália, conseguindo a sua unificação e impondo-se à Europa como potência, depois de ter sacudido o jugo da casa de Áustria e do papado; a própria Espanha ensaiou também a forma republicana, e deduziu da sua história a reorganização federal

tugal» (Teófilo Braga, Las Nacionalidades, in «O Positivismo», n. ${ }^{\circ} 4$, I ano, Abril-Maio, 1879, p. 306). Veja-se ainda Teixeira Bastos, Comte e o Posivitismo, p. 114. Por conseguinte, o federalismo não implicava a alienação das nacionalidades ibéricas, mas exigia a sua subdivisão em Estados. Era o que assinalava Sampaio Bruno quando se referia a este assunto, escrevendo: «sem embargo, o plano de federação republicana dos Estados peninsulares (não de Espanha unida com Portugal isolado, mas, ao contrário, da Espanha fragmentada com Portugal unido) continuava oferecendo para Portugal um prospecto redutor, segundo assim o julgávamos» (SAMPaio Bruno, Os Modernos Publicistas Portugueses, p. 133).

(1) «Os países latinos, a França, a Itália, a Espanha, Portugal constituem, para o efeito das ideias, dos princípios, dos costumes, uma estreita confederação moral, governada em espírito pelo mais adiantado e pelo mais instruído dos Estados federados. O país dirigente é a França. É ao seu impulso que obedecem fatalmente em Portugal a arte, a literatura, a poesia, o direito, a política. - A França acaba agora de dar um passo inteiramente novo na política moderna: funda a república em nome da ordem» (TeófILo Braga, Historia das Ideias Republicanas em Portugal, pp. 284-285). Sobre a teorização positivista deste francocentrismo, veja-se Augusto Сомте, Cours, vol. 6, pp. 279-282 e 536-545.

(2) $\mathrm{Na}$ verdade, este ecumenismo diversificado foi comum a todos os nossos juristas e pode ser sintetizado com esta afirmação de MANUEL Emídio GARCIA: «esta tendência de tal modo se vai acentuando, que muitos prevêem que, no futuro, a Humanidade formará uma completa federação, tendo por precedente a formação de federações parciais entre nações e famílias de povos, como a dos povos e nações latinas com o seu centro de convergência e irradiação - a França, sem dúvida a Nação mais adiantada e o Povo mais progressivo da velha Europa, a qual pela Federação Latina entrará no período activo e fecundo do seu rejuvenescimento social» (Manuel Emídio Garcia, Direito Ecclesiastico, Coimbra, Typ de Luiz Cardoso, 1896, p. 202). 
em estados livres regendo o tipo da nacionalidade portuguesa; a França, pelos sangrentos desastres de 1870, extirpou de si a legenda napoleónica, e retomou o seu lugar nos destinos da Europa pela sua república formada depois de dois deploráveis ensaios. Tudo nos revela que a civilização ocidental renasce, e com a coesão consciente, como se conhece pela aspiração do Pan-latinismo. A sua influência será profundíssima, porque há-de determinar na Europa a fundação das federações naturais de raça, como o Pan-germanismo e o Pan-islavismo, solidários da civilização continental, cujo carácter íntimo consiste no justo acordo entre o individualismo e a colectividade perante o mesmo fim» (1).

\section{Republicanismo e federalismo}

Foi com esta mistura positivístico-proudhoniana que o movimento positivista procurou demonstrar a inexistência de um antagonismo real entre os defensores da república unitária e os adeptos do republicanismo federalista. A seus olhos, a polémica não passava de um mal entendido teórico, alimentado por quesílias pessoais. Ora, como sublinhava TeófILo, diante das grandes ideias deviam cessar as disputas e, se todos reconheciam em que condições a república devia ser implantada em Portugal, tornava-se evidente que «pela pequenez do nosso território a forma republicana deve ser unitária; pela vizinhança com a Espanha, e como garantia perpétua da autonomia da nossa nacionalidade, deve ser federal. As duas formas não são incompatíveis; pelo contrário, são conexas na dupla relação da independência interna, e na relação também independente nos Estados Unidos Peninsulares» (2).

Pode dizer-se que esta atitude conciliatória deu os seus frutos dentro do movimento republicano. Com a unificação partidária nos inícios da década de oitenta, as teses do descentralismo e do federalismo, ainda que não fossem as palavras de ordem privilegiadas do partido, passaram a constituir uma das notas caracterizadoras da sua ideologia.

Sintomaticamente, ainda em 1893, quando em Badajoz se realizou o primeiro encontro oficial entie os republicanos portugueses e espanhóis

(1) TeÓfilo Braga, Mesologia das Civilizações, in «Era Nova», Lisboa, Escriptorio da «Era Nova», 1881, p. 496.

(2) Teófilo Braga, Historia das Ideias Republicanas em Portugal, p. 221. 
e foram apresentadas as Bases em que deveria assentar o futuro convénio entre as duas repúblicas, era ainda o ideal federalista, pautado pelos princípios positivistas, que fundamentava ideologicamente o seu articulado (1).

No entanto, é indesmentível que, depois do climax polémico dos anos setenta e oitenta, as exigências federalistas passaram a ser mais uma figura retórica, do que um ponto programático de concretização possível a curto ou a médio prazo. Não obstante, isso não invalidou o seu constante peso doutrinal na caracterização de um republicanismo que, apesar de crescentemente ir assumindo um conteúdo mais nacionalista, se manteve aberto à dimensão ecuménica exigida pelo desenvolvimento das forças produtivas no modo de produção capitalista. Assim se explica que Manuel de Arriaga, velho companheiro de Té́filo e Garcia e primeiro Presidente da República eleito, proclamasse ainda em 1907: "o princípio federativo é hoje o abc de todo o reformador social que ama e quer a liberdade e o bem estar dos indivíduos e dos povos. Nada há a acrescentar ao que sobre esta verdade fundamental do credo democrático escreveram J. Proudhon, Henriques Nogueira e Pi y Margall» (2).

\section{CONCLUSÃo}

De tudo o que ficou exposto, torna-se claro que o republicanismo, desde os seus primórdios, não visou qualquer transformação radical da sociedade portuguesa. Foi, sobretudo, um movimento contestatário de uma forma específica de estado capitalista e da ideologia católico-reaccionária ainda dominante, que pugnou pela harmonização das instâncias do modo de produção capitalista (económica, política, ideológica), de maneira a torná-las irreversivelmente homogéneas e adequadas aos interesses das classes médias.

Por sua vez, a importância do positivismo heterodoxo resultou principalmente da maneira actualizada como foram fundamentadas

(1) No nosso estudo sobre MANuel Emídio GaRCIA desenvolveremos o significado deste encontro para os movimentos republicanos peninsulares.

(2) MANuel De Arriaga, Harmonias Sociaes - O problema humano e a futura organização social, Coimbra, França Amado, 1907, p. 56. 
as ideias antigas em que assentava a aspiração republicana. Isto não admira-pois num período em que o impacto da revolução científico-industrial começava igualmente a fazer-se sentir entre nós, num momento em que as ciências (e as ideologias cientistas) gozavam de um carisma quase unanimemente aceite, o enroupamento positivista das expectativas demo-liberais e republicanas dava convencimento à argumentação e predispunha os espíritos para a aceitação da inevitabilidade das suas conclusões. Renovava-se, assim, a tradição do progressismo iluminista, só possível tão tardiamente devido ao facto de ter sido lenta a hegemonização das relações sociais capitalistas. E a força social das classes médias, fortalecidas por esse processo, explica o largo acolhimento que a filosofia de COMTE e de seus continuadores heterodoxos teve no seio de camadas intelectuais, que tanto rejeitavam o conservadorismo da aristocracia como o revolucionarismo comunalista, aspirando somente a um evolucionismo que consumasse a ruptura de 1820 .

Como se viu, o positivismo deu cabal cobertura a todo este ideário, já que, sendo o republicanismo de então um movimento privilegiador da luta ideológica, fornecia-lhe argumentos decisivos no combate contra os conteúdos e as instituições em que a ideologia monárquico-clerical se expressava e reproduzia. De facto, foi uma doutrina que se adequou optimamente aos objectivos super-estruturais do movimento, nomeadamente através da contestação cientista das teses ultramontanas, rejuvenescidas com as então recentes decisões do Concílio Vaticano I. Baseando-se nos princípios do agnosticismo ontológico e no teleologismo da lei dos três estados, que apontavam para a morte definitiva do sentimento religioso, o republicanismo positivista pôde actualizar com acutilância a velha tradição do anti-clericalismo jacobino e liberal. Em nome do advento necessário da positividade, justificavam a urgência de extirpar o jesuíta que habitaria ainda a mentalidade de cada português (1) e, com o derramamento de uma educação secular e cientificada, pensavam poder extinguir pacificamente as religiões e construir uma sociedade definitivamente desalienada (2).

(1) Veja-se Júlio de Matos, O Jesuitismo nos Seculares, in "Era Nova», pp. 295 e ss.; Teixeira Bastos, Considerações Geraes sobre a Philosophia Positiva, in «Idem», p. 532.

(2) Veja-se Carrilho Videira e Teixeira Bastos, op. cit., pp. 31-33; Teixeira Bastos, Fim das Religiões, in "O Positivismo», n. ${ }^{\circ}$ 4, II ano, Abril-Maio, 1880, 
A querela foi tão acesa, que lutar pela república tornou-se igualmente sinónimo de pugnar não só pela radical separação entre a igreja e o estado, mas também pela completa laicização das consciências e das instituições de educação e ensino. E, embora em nome dos princípios demo-liberais aceitassem, transitoriamente, a liberdade de culto, é indisçutivel que a aspiração última dos republicanos, em geral, e dos nossos positivistas heterodoxos, em particular, radicava na intenção de fomentar uma ideologia (cientista) em que o homem não mais estaria sujeito às «trevas» teológicas.

Contudo, não se pense que a este vazio religioso correspondia uma completa ausência de relações morais entre os indivíduos. A fraternidade jacobina (e maçónica), agora corroborada com o preceito comteano de vivre pour les autres (1), continuava a ser a norma máxima de felicidade na terra. Quer isto dizer que a ética de alteridade não possuia a dimensão transcendental dada pelo cristianismo, nem necessitava da fundamentação apriorista do kantismo, nem exigia a diluição do indivíduo defendida pelo exagero totalitário e filantrópico de Cомте. Os seus fundamentos estariam inscritos na ordem das coisas e seriam observáveis quer nas sociedades animais, quer nas humanas. Por isso, como sustentavam os utilitaristas, desde Bentham até Bain, Stuart Mill, Darwin e Spencer (2), Júlio de Matos (3),

pp. 286-296; Téófllo Braga, Systema de Sociologia, pp. 57 e ss., 70, 309 $-311,337,343$.

(1) Veja-se Auguste Cомте, Catéchisme Positiviste, pp. 225-226, e Système, t. I, pp. $692-693$; t. II, pp. $65-66,78,173$, 459; t. III, pp. XXXII, 76-77, 253; t. IV, p. 207.

(2) De facto, para além de argumentações particulares, a base do utilitarismo foi o principio benthamiano the greatest happiness of the greatest number. Sobre esta ética tipicamente capitalista, veja-se Jfremy Bentham, Oeuvres, Bruxelles, Société Belge de Librairie, 1840, pp. 426-538; Stuart Mill, Utilitarismo, Coimbra, Atlântida, 1976, pp. 17 e ss., e An Examination of Sir William Hamilton's Philosophie, London, Longmans Green, 1889, pp. 245-244; DARWIN, L'Origine des Espèces, Paris, Schleichee Frères, s.d., pp. 66-143; GuYAU, La Morale Anglaise Contemporaine, Paris, Félix Alcan, 1885, pp. 1-63; Pedro Laín Entralgo, Teoria e Realidade del Otro, t. I, Madrid, Revista Ocidental, 1968, pp. 72 e ss..

(3) Veja-se Júlio DE MATos, Encore l'Origine et la Sanction de la Morale, Lettre à M. Pompery, in "O Positivismo», n. ${ }^{\circ} 4$, II ano, Abril-Maio, 1880, pp. 302-304, e $O$ Problema da Felicidade Individual, in «Idem», n. ${ }^{\circ} 3$, II ano, Fevereiro-Março, 1880, pp. 182-196. Aqui, distanciando-se dos exageros altruistas de CомтE 
Té́fILo ( $\left.{ }^{4}\right)$ e outros repetiam, entre nós, que praticar a fraternidade em ordem à obtenção do máximo de felicidade impunha a adequação do egoísmo natural de cada indivíduo ao egoísmo dos restantes. O individualismo económico e político justificava-se num individualismo moral e, tal como deveria acontecer nas relações económicas, a realização do máximo interesse de cada um, desde que mediada pela aceitação de idêntica possibilidade para os outros, realizaria a definitiva harmonia e felicidade há muito justificadas pelas filosofias iluministas da perfectibilidade. Propunha-se, assim, que à morte do deus-homem e à rejeição da humanidade-deus, sucedesse uma sociedade que, pelas mãos da república, traria o radioso advento de um reino em que, apesar das desigualdades sociais, a felicidade para o maior número seria possível.

Em face de tudo o que foi exposto, parece-nos indiscutível que foi a capacidade de resposta aos problemas que inquietavam os sectores mais esclarecidos das classes médias, revelada pelo positivismo, que permitiu um tão íntimo acasalamento entre a doutrina e o movimento republicano. Acasalamento esse que veio a traduzir-se, igualmente, numa posição dominante em relação a outras correntes, como o kantismo e o proudhonismo, que enformavam o ideário de alguns paladinos da causa anti-monárquica.

Por outro lado, a crescente força social e política que tais sectores da população portuguesa adquiriram levou a que a sua filosofia se transformasse também em doutrina hegemónica no horizonte cultural de então. Daí que, para além da presença de leituras mais direitistas do positivismo (neo-garrettianos e, depois, integralismo lusitano) e apesar de, em muitos casos, não encontrarmos a ligação que frequentemente existia entre a opção filosófica e a opção partidária, é um facto que o positivismo sobredeterminou todos os campos do saber. Além do mais, a força da sua presença era tal que acabou igualmente por definir o horizonte polémico de pensadores (e correntes) de pendor metafísico. Desde Antero, Oliveira Martins, Sampaio

e Littré, Júlio de Matos seguia os positivistas franceses Pompery e Paulham (cf. POMPery, L'Origine et la Sanction de la Morale, in «O Positivismo», n. ${ }^{\circ} 4$, II ano, Abril-Maio, 1890, pp. 296-301, e Fr. Paulham, Le Fondement de la Morale, in «Philosophie Positive, Revue», t. XXI, Juillet et Décembre, 1878, pp. 428-442).

(4) Veja-se Teófilo Braga, Systematização da Moral, in «O Positivismo», n. ${ }^{\circ}$ 3, II ano, Fevereiro-Março, 1880, pp. 303 e ss.. 
Bruno, Cunha Seixas, Domingos Tarroso, passando pelo saudosismo e pelo racionalismo searista, até às actuais contestaçðes das propostas neo-positivistas, tudo isto se torna ininteligível se não considerarmos a importância que o positivismo teve entre nós.

Aqui, limitámo-nos somente a levantar as linhas gerais explicativas da forma privilegiada que a sua assimilação assumiu em Portugal. Temos consciência do valor provisório das teses defendidas, bem como do seu carácter demasiadamente genérico. Mas isso compreende-se, se compararmos o estado actual das investigações com a riqueza histórica do fenómeno. Só um estudo monográfico da vida e obra dos seus principais representantes, articulado com a análise da sua importância em todos os campos de actividade intelectual, poderá fornecer a riqueza de pormenor e a visão de conjunto necessárias à explicação dos quadros mentais em que o Portugal contemporâneo (ainda) se move.

Fernando de Almeida Catroga 